SH

365

A4M7

1913

MOL. 

DEPARTMENT OF COMMERCE AND LABOR BUREAU OF FISHERIES

GEORGE M. BOWERS, Commintoner
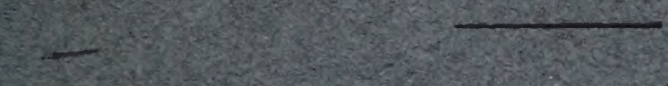

Division of Sectional if prory

CONDITION AND EXIENT OF THE NATURAL OYSTER BEDS AND BARREN BOTTOMS OF MISSISSIPPI SOUND, ALABAMA

\author{
BY H. F. MOORE \\ Assistant in Charge of Scientific Inquiry
}

Bureaw of Fisheries Document No. 769

WASHINGTON

COVERNMENT PRINTING OPFICE 1913 

DEPARTMENT OF COMMERCE AND LABOR

BUREAU OF FISHERIES

GEORGE M. BOWERS, Commissioner

CONDITION AND EXTENT OF THE NATURAL OYSTER BEDS AND BARREN BOTTOMS OF/ MISSISSIPPI/SOUND, ALABAMA

\author{
By H. F. MOORE
}

Assistant in Charge of Scientific Inquiry

Bureau of Fisheries Document No. 769

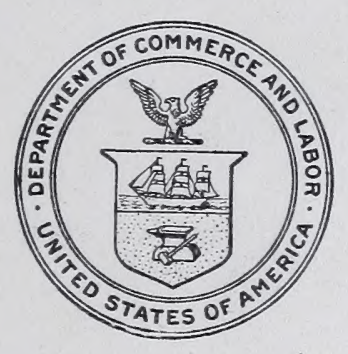

WASHINGTON

GOVERNMENT PRINTING OFFICE 1913 



\title{
CONDITION AND EXTENT OF THE NATURAL OYSTER BEDS AND BARREN BOTTOMS OF MISSISSIPPI SOUND, ALABAMA
}

\author{
BY H. F. MO0RE \\ Assistant in Charge of Scientific Inquiry
}

Bureau of Fisheries Document No. 769 



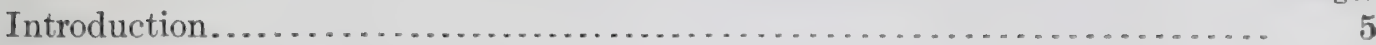

Methods of the survey ..................................... 6

Description of the natural beds:

King's Bayou Reef. . . . . . . . . . . . . . . . . . . . . . . . . . . . . . . 12

Buoy Reef. . . . . . . . . . . . . . . . . . . . . . . . . . . . . 13

Cedar Point Reef......................................... 15

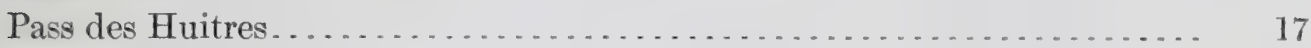

Pass des Huitres Flats... . . . . . . . . . . . . . . . . . . . . . . . 18

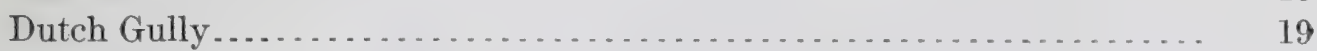

West side of Dutch Island . . . . . . . . . . . . . . . . . . . . . . . . . 20

Big Gully . . . . . . . . . . . . . . . . . . . . . . . . . . . 21

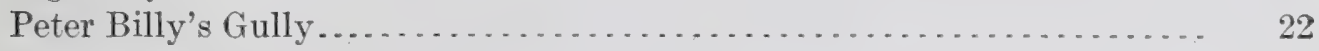

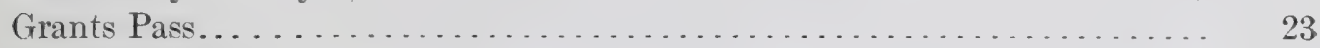

Pass aux Herons. . . . . . . . . . . . . . . . . . . . . . . . . . . . . . . 25

Redfish Gully ........................................... 27

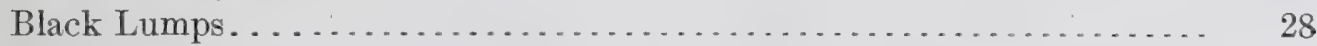

West side of Little Dauphin Island... . . . . . . . . . . . . . . . . . . . 29

Mussel Gully ........................................... 29

Sand Reef.................................................. 30

Dauphin Island Bay ... . . . . . . . . . . . . . . . . . . . . . . . . . ${ }_{31}$

Sprinkels Bay ...................................... 33

Collier Bay. . . . . . . . . . . . . . . . . . . . . . . . . . . . . . 34

Off East Base signal......................................... 34

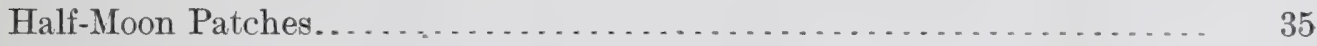

Heron Bay, east side... . . . . . . . . . . . . . . . . . . . . . . . . . 35

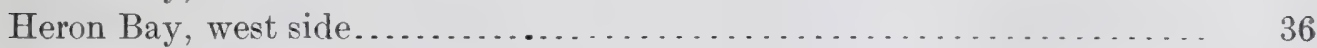

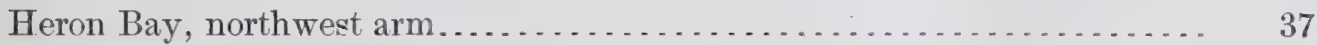

Middle Ground, Fowl River Bay......................... 38

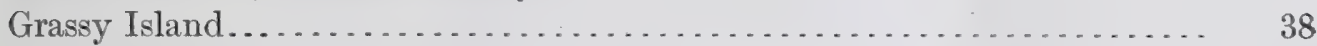

Goose Bayou. . . . . . . . . . . . . . . . . . . . . . . . . . . . . . . . $\quad 39$

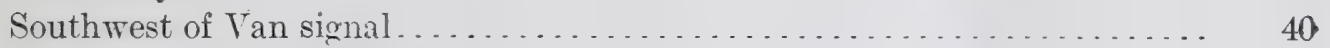

East side of Marsh Island . . . . . . . . . . . . . . . . . . . . . . . . 40

Portersville, State-planted bed... . . . . . . . . . . . . . . . . . . . . . 41

Portersville Bay, north end.... . . . . . . . . . . . . . . . . . . . . . 41

West side of Coffee Island................................. 42

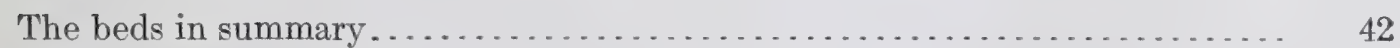

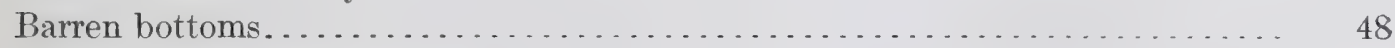

Near Half-Moon Patches... . . . . . . . . . . . . . . . . . . . . . . . . 49

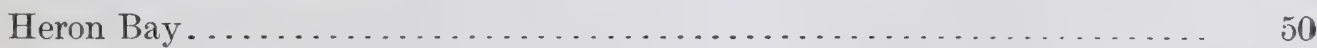

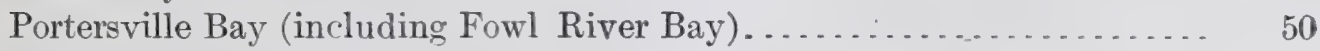

Mississippi Sound, south of Portensville Bay .................. 50

West of Coffee Island... . . . . . . . . . . . . . . . . . . . . . . . . . . . 50

North end of Coffee Island... . . . . . . . . . . . . . . . . . . . 50

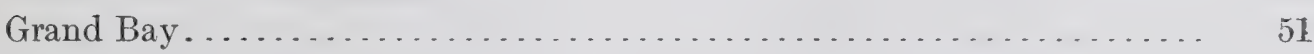

South of Grand Bay ...................................... 51 
General physical and biological conditions:

Tides and currents................................... 51

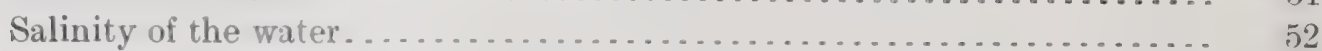

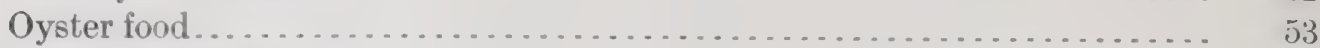

Oyster enemit. . . . . . . . . . . . . .

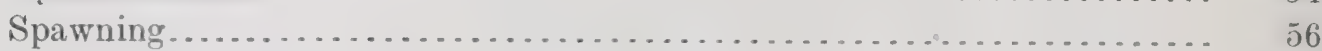

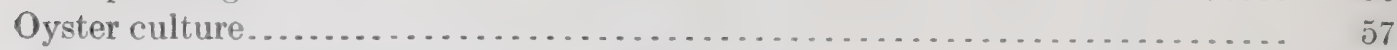

Résumé, conclusions, and recommendations ....................... 58

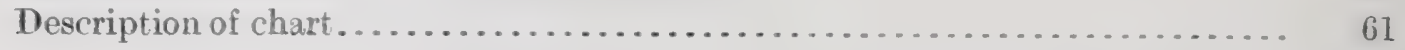




\title{
CONDITION AND EXTENT OF THE NATURAL OYSTER BEDS AND BARREN BOTTOMS OF MISSISSIPPI SOUND, ALA.
}

\author{
By H. F. Moore, \\ Assistant in Charge of Scientific Inquiry.
}

\section{INTRODUCTION.}

At the request of the Alabama Oyster Commission, through its president, Mr. John Craft, and on the representations of the several Senators and Representatives in Congress from that State, the Bureau in February, 1910, made a preliminary examination of the oysterproducing regions of Mobile Bay and Mississippi Sound. It appeared from this examination that the oyster interests were of sufficient present and prospective importance to warrant a survey and report on the productive and barren bottoms of Mississippi Sound.

The triangulation of the region was begun by the Coast and Geodetic Survey, under an arrangement for cooperation between the two bureaus, during the summer of 1910 , and was maintained so far in advance of the requirements of the biological and hydrographic work of the Bureau of Fisheries that the latter never suffered a moment's delay for lack of triangulation points.

Although the work performed by the Coast and Geodetic Survey in connection with this investigation is of a character not requiring treatment in the text of this report, the State authorities charged with the administration of the oyster laws should appreciate it as that part of the results which has the most enduring value. The accurately determined and substantially marked stations furnish to the State an invaluable and permanent basis for the survey and delimitation of leaseholds of barren bottom for purposes of oyster culture, and if properly used will enable Alabama to avoid the embarrassment and litigation which elsewhere have been consequent on faulty surveys and descriptions. No survey not properly based in and referred to this triangulation should be countenanced in oyster leases granted by the State.

The biological and hydrographic survey, which was conducted by the Bureau of Fisheries, began about the middle of November, 1910, when the steamer Fish Hawk arrived in Mobile Bay, and it was concluded in May, 1911, part of the interim being employed in a similar survey in Mississippi waters. The purpose of the survey was the 
ac'urate determination of the location, extent, and condition of the natural oyster beds and the examination of the barren bottoms in relation to their adaptability to oyster culture.

No oyster survey of the region covered by this report had been made previously, although the important beds arljacent to Grant's Pass had been the subject of reconnoissance in $1894 .^{a}$

\section{METHODS OF THE SURVEY.}

The methods employed were those pursued in former surveys of like character and are explained in detail in a description of the beds of the James River, ${ }^{b}$ from which some of the following is repeated:

A "boat sheet" was prepared, on which were accurately platted the positions, as determined by triangulation, of lighthouses, buildings, tripods, etc., used as shore signals. These data were furnished by the United States Coast and Geodetic Survey.

The oyster beds were discovered by soundings with a lead line, but principally by means of a length of chain dragged over the bottom at the end of a copper wire running from the sounding boat. The wire was wound on a reel and its unwound length was adjusted to the depth of water and the speed of the launch, so that the chain was always on the bottom. Whenever the chain touched a shell or an oyster the shock or vibration was transmitted up the wire to the hand of a man whose sole duty it was to give heed to such signals and report them to the recorder.

The launches from which the soundings were made were run at a speed of between 3 and 4 miles per hour. At intervals of three minutes - in some cases two minutes-the position of the boat was determined by two simultaneous sextant observations of the angles between a set of three signals, the middle one of which was common to the two angles, the position being immediately platted on the boat sheet. At regular intervals of 15 seconds, as measured by a clock under the observation of the recorder, the leadsman made a sounding and reported to the recorder the depth of water and the character of the bottom, immediately after which the man at the wire reported the character of the chain indications since the last sounding-that is, whether they showed barren bottom or dense, scattering, or very scattering growths of oysters.

With the boat running at 3 miles per hour the soundings were between 80 and 90 feet apart, and, as the speed of the boat was uniform, the location of each was determinable within a yard or two by dividing the platted distance between the positions determined by the sextant by the number of soundings. The chain, of course, gave

a Report of a reconnoissance of the oyster beds of Mobile Bay and Mississippi Sound, Ala., by Homer P. Ritter, assistant, United States Coast and Geodetic Survey. Published in Bulletin United States Fish Cornmission, vol. XV, 1895, p. 325-329, pl. 56-63.

$b$ Moore, H. F.: Condition and extent of the oyster beds of James River, Va. Bureau of Fisheries Document No. 729 . 
a continuous indication of the character of the bottom, but the record was made at the regular 15 -second intervals observed in sounding.

The chain, while indicating the absence or the relative abundance of objects on the bottom, gives no information as to whether they are shells or oysters, nor, if the latter, their size and condition. To obtain these data it was necessary to supplement the observations already described by others more definite in respect to the desired particulars. Whenever, in the opinion of the officer in charge of the sounding boat, such information was required, a numbered buoy was dropped, the time and number being entered in the sounding book. Another launch, following the sounding boat, anchored alongside the buoy, and a quantity of the oysters and shells were tonged up, separated by sizes, and counted.

This boat at each station made a known number of "grabs" with the oyster tongs, exercising care to clean the bottom of oysters as thoroughly as possible at each grab. In a given depth of water and using the same boat and tongs, an oysterman will cover practically the same area of the bottom at each grab, but, other factors remaining the same, the area of the grab will decrease with an increase in the depth.

Careful measurements were made and tabulated showing the area per grab covered by the tonger employed on the work at each foot of depth of water and for each pair of tongs and boat used. With these data, and knowing the number of "grabs," the number of oysters of each size per square yard of bottom was readily obtainable by simple calculation. The following example will illustrate the data obtained and the form of the record:

Department of Commerce and Labor, BUREAU OF FISHERIES.

Field record of examinations of oyster beds.

General locality, Mississippi Sound, Ala.

Local name of oyster ground, Pass des Huitres.

Date, December 29, 1910. Time, 1.05 p. m.

Angle, C 193-C 194. Buoy No. 2.

Depth, 3 feet. Bottom, Hard.

Condition of water, Clear.

Density, 1.015. Temperature, $58^{\circ} \mathrm{F}$.

Current, ............... Stage of tide, Flood.

Tongman, Bryant.

No. grabs made, 6 .

Tongs, 10 feet.

Total area covered, $2.4 \mathrm{sq}$. yds.

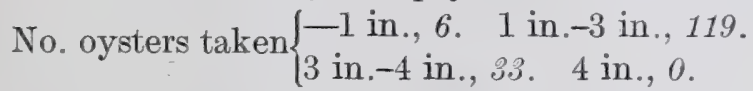

Quantity shells, 0 .

Result $\left\{\begin{array}{l}\text { Spat per square yard, 2.5. } \\ \text { Culls per square yard, 45.4. } \\ \text { Counts per square yard, 13.7. }\end{array}\right.$ 
This furnishes an exact statement of the condition of the bed at the spot, which can be platted on the chart with error in position of not more than a few yards. From the data obtained a close estimate may be formed of the number of bushels of oysters and shells per acre in the vicinity of the examination, and, by multiplying the observations, for the bed as a whole. In the course of the survey 775 observations were made at various places, principally on the natural rocks, but some on the barren bottoms also.

In estimating the productiveness of the bottoms it appeared desirable to use the method employed in Delaware Bay ${ }^{a}$ rather than that followed in the James River survey.

Where tongs are used exclusively a bed with a given quantity of oysters lying in shoal water is more valuable commercially than one with the same quantity of oysters in deep water, owing to the fact that the labor of the tonger is more efficient on the former. As has been pointed out, the area covered by a "grab" decreases with the depth, other factors being the same; and, moreover, the deeper the water the greater is the labor involved in making the grab and the smaller is the number of grabs which can be made in a given time. Where, however, the depth is practically uniform and shoal, as in the region treated in this report, it is unnecessarily refined and laborious to make such allowance for depth, and it is nearly as accurate and satisfactory to rate the bottoms in accordance with an arbitrary standard.

The classification adopted in this report is as follows:

Depleted bottom...............................

Very scattering growth....................

Scattering growth................................

Dense growth ...........................

In this classification no oysters less than 3 inches in length are considered, as the rating is made solely in respect to what are assumed to be marketable. It may therefore occur that bottom covered by an enormous growth of small oysters may be regarded, both in the text and on the chart, as depleted on account of the few large oysters which it bears. A reference to the tables which accompany the description of each bed will show cases of this kind. "Depleted bottom" is in a measure an unfortunate term, as it implies that it has retrograded in productiveness, whereas in reality in many cases it may be barren bottom gradually changing to productive. The term is employed to designate a definite present condition without regard to the past, and is retained despite its false implication, because no better has been suggested.

a Condition and Extent of the Natural Oyster Beds of Delaware. By H. F. Moore, assistant, United States Bureau of Fisheries. Bureau of Fisheries Document No. 745, 1911. 
Under the biological and economic conditions obtaining in Mississippi Sound in 1910-11, the bottom rated as bearing a scattering growth, on which there are more than 75 bushels of marketable oysters per acre, is regarded as the least productive bottom capable of furnishing a livelihood to the tongers. Some of the very scattering growth may be capable of supporting a fishery for market, but most of it is not. On the other hand, some of the dense growth is of a character to make it practically worthless for market purposes, and while the oysters are abundant enough, the economic conditions are not such as to warrant tonging.

The barren bottom, which constitutes by far the greater part of the area covered by the survey, was examined principally with respect to the character, stability, and fixity of its constituent materials. This part of the investigation was more thorough and accurate than in any previously conducted, principally through the use of a mudsounding machine devised by the writer several years ago. In previous surveys the character of the bottom has been determined by the indications of the sounding lead and pole, which are largely matters of opinion and will not correspond with any accuracy in the hands of different persons. To overcome this difficulty the Bureau now employs the instrument figured on next page. It consists of a large annular bottom $(\mathrm{P})$, from which rises a tripod $(\mathrm{T}, \mathrm{T})$ supporting two castings $(\mathrm{C}$ and $\mathrm{C})$. Passing freely through shaped orifices in the castings is a steel rod (R) $46 \frac{1}{2}$ inches long, provided with a rack and a plunger head $(\mathrm{H}) 3$ inches long and $\frac{7}{8}$ inch in diameter. Linked to the underside of the lower casting is a pawl (X) connected to the sliding weight $(\mathrm{W})$, which, when at rest, engages with the rack in such manner as to prevent the fall of the rod.

To use the instrument, a pole of sufficient length is inserted in the eyes at the side of the castings. The rod is raised as far as it will go and is automatically locked in position by the rack and pawl. The instrument is then lowered until it rests on the bottom and the rod is released by pulling on a line attached to an eye at the upper end of the weight. As the plunger always falls through the same distance, it strikes the bottom with a uniform impact, and the depth of its penetration is a comparative measure of the consistency of the bottom.

In practice, the instrument is used from an anchored boat, and to secure a representative reading from 6 to 10 tests are made close together. Any markedly aberrant readings are eliminated, on the assumption that the plunger has either come into contact with an accidental obstruction, such as a shell, or has fallen into a crabhole or other minor cavity. The average of the remaining depths of penetration, read off in inches in a scale stamped on the rod, is 


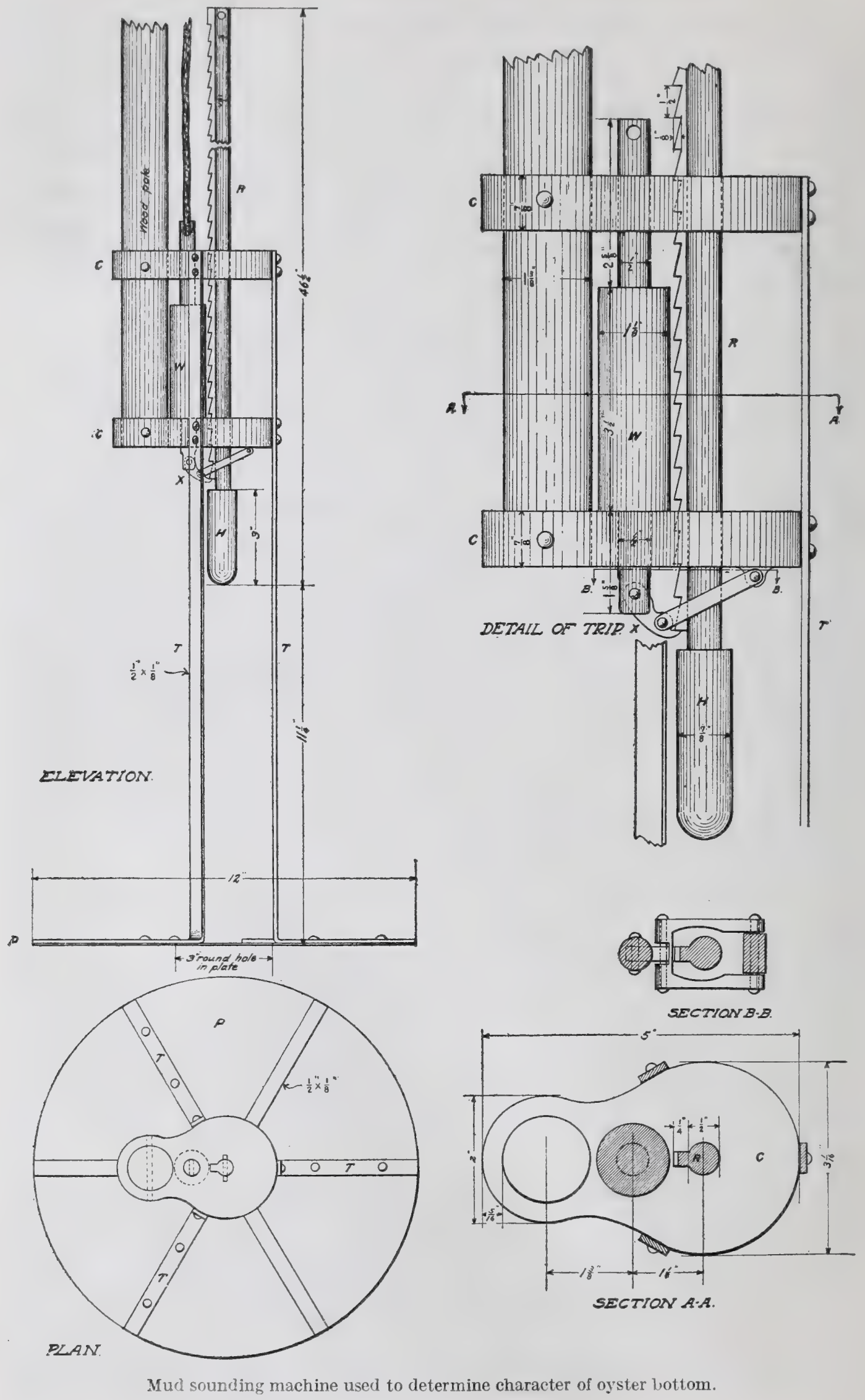


regarded as the index of the bottom consistency. The following arbitrary scale is adopted in this report.

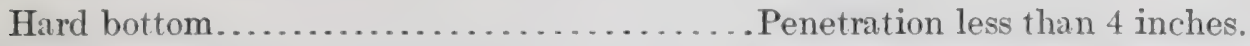

Stiff ................................... Penetration between 4 and 8 inches.

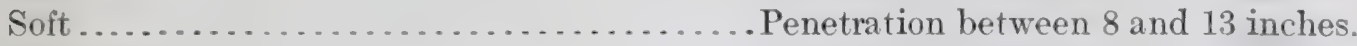

Very soft ..............................

Ooze ................................. Penetration over 18 inches.

On the accompanying chart the consistency of the bottom is indicated by symbols which are more readily read than lettering-a black circle indicating hard bottom; a black semicircle, stiff mud; a black quadrant, soft mud; a circle containing two crossing diameters, very soft mud; and a circle with one diameter, ooze. Bottom falling within the first two classes, provided it be not shifting sand, is firm enough for oyster planting; the harder the bottom the more thickly the oysters may be planted without danger of becoming engulfed. Soft bottom should be used with care, and toward its upper limits may reouire preliminary hardening with sand or shells. Very soft bottom and ooze should not be considered. The instrument described has been given a thorough test and has shown itself to be satisfactory for the purpose of oyster surveys. Its readings are reliable where the consistency of the bottom is fairly uniform in the stratum penetrated, but there is likely to be an error of interpretation in the case of a hard sand or shell bottom overlaid by several inches of soft mud. Such cases are readily detectable, however, by probing with a pole, as is always done where the instrument is used.

In the prosecution of the work previously described, 357.1 miles of soundings were run and the chain was dragged over the bottom for the same distance, 16,960 soundings were made, and 3,340 angles for position of the boat were taken. Oysters were tonged, counted, and measured, and other biological observations made at 464 stations, and the consistency of the bottom was tested at 311 places exclusive of those on the oyster beds, a total of 775 places at which the bottom was examined. The survey covered a total area of 93,000 acres, of which 4,000 acres were oyster beds in which the sounding lines were closer together and the examinations made in more detail than on the barren bottoms.

The account of the oyster beds which follows proceeds from a detailed description of the several beds, with the data of all productive observations, to a consideration of the region as a whole and the requirements for its economic development. 


\section{DESCRIPTION OF THE NATURAL BEDS.}

KINGS BAYOU REEF.

The name Kings Bayou Reef was somewhat doubtfully applied by the pilot to an oyster bed lying about 5 miles northeast of the end of Cedar Point. It is about $1 \frac{1}{3}$ miles long and $\frac{1}{2}$ mile wide, its greater dimension being east and west, beginning 1 mile offshore in about 3 feet of water. This is an old reef, and, like the others in this part of Mobile Bay, it is built up in places several feet above the general level of the bottom. At its outer or offshore end the water shoals abruptly from 10 feet on the mud bottom to $6 \frac{1}{2}$ feet on the reef.

The extent and character of the oyster growth on this bed are shown in the following table:

Oyster Growth on Kings Bayou Reef.

\begin{tabular}{|c|c|c|c|c|c|c|}
\hline \multirow{2}{*}{ Character of oyster growth. } & \multirow{2}{*}{ Area. } & \multicolumn{2}{|c|}{ Oysters per acre. } & \multicolumn{3}{|c|}{ Estimated content of oysters. } \\
\hline & & $\begin{array}{l}\text { Under } 3 \\
\text { inches. }\end{array}$ & $\begin{array}{l}\text { Over } 3 \\
\text { inches. }\end{array}$ & Seed. & Market. & Total. \\
\hline $\begin{array}{l}\text { Dense............ } \\
\text { Very scattering. } \\
\text { Depleted....... }\end{array}$ & $\begin{array}{r}\text { Acres. } \\
39 \\
40 \\
3\end{array}$ & $\begin{array}{r}\text { Bushels. } \\
296 \\
205 \\
108\end{array}$ & $\begin{array}{r}\text { Bushels. } \\
234 \\
91 \\
6\end{array}$ & $\begin{array}{r}\text { Bushels. } \\
11,544 \\
8,200 \\
324\end{array}$ & $\begin{array}{r}\text { Bushels. } \\
9,126 \\
3,640 \\
18\end{array}$ & $\begin{array}{r}\text { Bushels. } \\
20,670 \\
11,840 \\
342\end{array}$ \\
\hline Total. & 82 & & & 20,068 & 12,784 & 32,852 \\
\hline
\end{tabular}

The dense area is hook-shaped in outline and extends along the entire northern and western edges of the reef, with a brief gap near its middle, and it is probable that the reef consisted formerly of two dense areas separated by soft mud. The oysters are mostly in clusters of 8 or 9 , often with very many small spat. The large oysters are long, oval, and thin edged. Very little débris was taken in the tongings.

The very scattering growths cover a compact area on the south side of the bed and extending between the two limbs of the dense area. On this part of the bed the depth varies from about $7 \frac{1}{2}$ to 10 feet, indicating that it is of more recent development than the denser parts. There is yet no considerable accumulation of shells. While the quantity of large oysters per acre is but about 40 per cent of the number found on the area of dense growth, small oysters are nearly as abundant, ranging in places between 91 and 496 bushels per acre.

The depleted area is a small patch separating the two areas of dense growth above alluded to. While large oysters are scarce, there is a considerable quantity of young growth.

The details of examination of Kings Bayou Reef follows. 
Details of Examination of Kings Bayou Reef.

\begin{tabular}{|c|c|c|c|c|c|c|c|c|c|}
\hline \multirow{2}{*}{$\begin{array}{l}\text { Angle } \\
\text { No. }\end{array}$} & \multirow{2}{*}{$\begin{array}{l}\text { Date of } \\
\text { examination. }\end{array}$} & \multirow{2}{*}{$\begin{array}{l}\text { Depth } \\
\text { of } \\
\text { water. }\end{array}$} & \multirow{2}{*}{ Character of growth. } & \multicolumn{3}{|c|}{$\begin{array}{l}\text { Oysters caught per } \\
\text { square yard. }\end{array}$} & \multicolumn{3}{|c|}{$\begin{array}{c}\text { Estimated quantity oys- } \\
\text { ters per acre. }\end{array}$} \\
\hline & & & & Spat. & Culls. & Counts. & Seed. & Market. & Total. \\
\hline 1 & Noy. 21, 1910 & $\begin{array}{l}\text { Feet. } \\
9.00\end{array}$ & Dense. & 6.5 & 35.5 & 11.0 & $\begin{array}{r}\text { Bush. } \\
294\end{array}$ & $\begin{array}{c}\text { Bush. } \\
176\end{array}$ & Bush. \\
\hline $\begin{array}{l}1 \\
2\end{array}$ & .... do....... & 9.00 & .... do & 2.5 & 12.5 & 12.0 & 105 & 192 & 297 \\
\hline 7 & .....do. & 9.00 & do & 4.5 & 17.5 & 6.0 & 154 & 96 & 250 \\
\hline 8 & do.. & 10.00 & . do & 31.2 & 64.2 & 43.2 & 672 & 691 & 1,363 \\
\hline 14 & .....do. & 7.00 & .do & 22.3 & 38.0 & 13.1 & 422 & 209 & 631 \\
\hline 5 & . do.. & 6.50 & do. & 9.5 & 24.5 & 18.0 & 238 & 288 & 526 \\
\hline 63 & Nov. 22,1910 & 5.50 & d & 10.0 & 11.1 & 9.0 & 148 & 144 & 292 \\
\hline 64 & .... do........ & 3.5 & .d & 14.7 & 32.2 & 9.1 & 3 & & 474 \\
\hline 65 & $\ldots$. do $\ldots$ & 6.00 & do. & 11.1 & 32.7 & 10.0 & 307 & 160 & 467 \\
\hline 3 & Nov. 21,1910 & 10.00 & Very scattering. & 7.4 & 9.0 & 4.5 & 115 & 72 & 187 \\
\hline 6 & .... do....... & 7.00 & ....do............ & 9.1 & 19.8 & 3.3 & 20 & 53 & 255 \\
\hline 9 & .... do........ & 8.00 & .... do. & 4.7 & 18.1 & 3.4 & 151 & 54 & 205 \\
\hline 10 & . do... & 6.50 & de & 21.1 & 49.8 & 18.0 & 496 & 288 & 784 \\
\hline 11 & do. & 6.00 & do & 14.0 & 11.5 & 1.6 & 178 & 26 & 204 \\
\hline 12 & d & 6.00 & .....u & 6.7 & 6.3 & 3. & 91 & 56 & 147 \\
\hline 13 & & 7.00 & Depleted. & 8.4 & 1.4 & .0 & 69 & 0 & 69 \\
\hline 4 & do. & 8.50 & .....do. & 8.1 & 12.9 & .8 & 147 & 13 & 160 \\
\hline
\end{tabular}

BUOY REEF.

This reef, as defined in the present report, consists of a number of detached bodies of oysters varying from 1 to upward of 100 acres each. The name is apparently somewhat indefinitely applied, but is used here to designate the series of beds beginning with that lying south of the wreck buoy off Cedar Point and stretching northward for a distance of about $1 \frac{3}{4}$ miles. This apparently includes all or part of what Ritter describes as Birmingham Reef. The large area lying south of the buoy is connected with Cedar Point Reef by an area of very scattering growth which doubtless marks an original line of separation between the two, over which oysters have been spread by the operation of dredges. In general all of these beds have sharply defined borders, rising abruptly a foot or two above the surrounding muddy bottom. They are resorted to principally by dredgers to whose use they are set apart by law. The oysters are in clusters.

The distribution of oysters according to density of growth is shown in the following table:

Oyster Growth on Buoy Reer.

\begin{tabular}{|c|c|c|c|c|c|c|}
\hline \multirow{2}{*}{ Character of oyster growth. } & \multirow{2}{*}{ Area. } & \multicolumn{2}{|c|}{ Oysters per acre. } & \multicolumn{3}{|c|}{ Estimated content of oysters. } \\
\hline & & $\begin{array}{l}\text { Under } 3 \\
\text { inches. }\end{array}$ & $\begin{array}{l}\text { Over o } \\
\text { inches. }\end{array}$ & Seed. & Market. & Total. \\
\hline $\begin{array}{l}\text { Dense............ } \\
\text { Scattering........ } \\
\text { Very scattering.. } \\
\text { Depleted......... }\end{array}$ & $\begin{array}{r}\text { Acres. } \\
202 \\
34 \\
19 \\
12\end{array}$ & $\begin{array}{r}\text { Bushels. } \\
209 \\
165 \\
76 \\
29\end{array}$ & \begin{tabular}{|r} 
Bushels. \\
324 \\
108 \\
62 \\
4
\end{tabular} & $\begin{array}{r}\text { Bushels. } \\
42,218 \\
5,610 \\
1,444 \\
348\end{array}$ & $\begin{array}{r}\text { Businels. } \\
65,448 \\
3,672 \\
1,178 \\
48\end{array}$ & $\begin{array}{r}\text { Bushels. } \\
107,666 \\
9,282 \\
2,622 \\
396\end{array}$ \\
\hline Total. & 267 & & & 49,620 & 70,346 & 119,966 \\
\hline
\end{tabular}


The dense growth covers about 75 per cent of the total area, and either constitutes the entirety of the several beds or forms a center fringed by less dense areas, as shown in the chart.

The oysters are in clusters containing a fair proportion of large individuals. In the areas of dense growth, the market oysters exceed, numerically and in volume, the young under 3 inches in length, but on the less densely populated parts of the beds young oysters preponderate over the old ones. The depth of water over the areas of dense growth varies trom 6 to $8 \frac{1}{2}$ feet and on the adjacent less dense parts of the beds it is usually a foot or two deeper:

A few drills were found here and some dead oysters, but in general the beds seem to be in good condition and capable of producing a good supply of oysters of indifferent quality. The market oysters on this and Kings Bayou and Cedar Point Reefs ran about 300 to the bushel, and it required over 700 of the small oysters under 3 inches in length to fill the same measure.

The following examinations were made:

Detalls of Examination of Buoy Reef.

\begin{tabular}{|c|c|c|c|c|c|c|c|c|c|}
\hline \multirow{2}{*}{$\begin{array}{l}\text { Angle } \\
\text { No. }\end{array}$} & \multirow{2}{*}{$\begin{array}{l}\text { Date of } \\
\text { examination. }\end{array}$} & \multirow{2}{*}{$\begin{array}{l}\text { Depth } \\
\text { of } \\
\text { water. }\end{array}$} & \multirow{2}{*}{ Character of growth. } & \multicolumn{3}{|c|}{$\begin{array}{l}\text { Oysters caught per } \\
\text { square yard. }\end{array}$} & \multicolumn{3}{|c|}{$\begin{array}{c}\text { Estimated quantity oys- } \\
\text { ters per acre. }\end{array}$} \\
\hline & & & & spat. & Culls. & Counts. & Seed. & Market. & Total. \\
\hline & & Feet. & & & & & Bush. & Bush. & Bush. \\
\hline 32 & Nov, 21, 1910 & 9.50 & Dense. . & 14.2 & 11.5 & 13.0 & 180 & 208 & 388 \\
\hline $\begin{array}{l}33 \\
34\end{array}$ & .....do............ & $\begin{array}{l}9.00 \\
8.00\end{array}$ & ..... do.. & 10.5 & 66.5 & $\begin{array}{l}34.5 \\
11.7\end{array}$ & $\begin{array}{l}540 \\
284\end{array}$ & & $\begin{array}{r}1,094 \\
471\end{array}$ \\
\hline $\begin{array}{l}34 \\
35\end{array}$ & ......do.... & $\begin{array}{l}8.00 \\
8.00\end{array}$ & .... do. & $\begin{array}{r}21.5 \\
5.2\end{array}$ & $\begin{array}{l}19.0 \\
21.7\end{array}$ & $\begin{array}{l}11.7 \\
17.4\end{array}$ & $\begin{array}{l}284 \\
188\end{array}$ & $\begin{array}{l}187 \\
278\end{array}$ & $\begin{array}{l}471 \\
466\end{array}$ \\
\hline 36 & .....do... & 7.00 & .... do.. & 11.5 & 37.8 & 19.2 & 345 & 307 & 65 \\
\hline 45 & ......do... & 10.50 & ..... do. & 11.7 & 31.0 & 22.8 & 25 & 365 & 66 \\
\hline 46 & .....do... & 10.00 & .....do. . & 2.8 & 27.8 & 15.0 & 214 & 240 & 45 \\
\hline 53 & do.. & 10.00 & ... do. & 7.2 & 21.1 & 13.9 & 198 & 222 & 42 \\
\hline 55 & .....do... & 10.00 & .... do.. & 25.0 & 19.4 & 27.3 & 311 & 437 & 74 \\
\hline 56 & .....do... & 8.00 & .....do. & 7.4 & 20.0 & 13.5 & 192 & 216 & 40 \\
\hline 98 & Nov. 22,1910 & 8.50 & ... do. & 7.7 & 16.3 & 39.0 & 16 & 625 & 79 \\
\hline 39 & Nov. 21,1910 & 8.00 & ... do. & 12.6 & 24.0 & 24.0 & 256 & 384 & 64 \\
\hline 40 & .....do......... & 7.00 & do. & 8.1 & 42.3 & 36.7 & 354 & 586 & 94 \\
\hline 86 & Nov. 22,1910 & 9.50 & do & .0 & 15.2 & 22.6 & 106 & 362 & 46 \\
\hline 87 & .....do.... & 8.00 & . do & .8 & 13.5 & 16. & 100 & 257 & 35 \\
\hline 88 & ..... do... & 8.00 &.$d$ & 8.3 & 24.3 & 20.4 & 2 & 327 & 55 \\
\hline 27 & Nov. 21,1910 & 7.50 & ..... do & 2.8 & 28.5 & 25.0 & 2 & 400 & 619 \\
\hline 29 & ......do... & 8.00 & ..... do & 10.0 & 32.5 & 17. & 29 & 280 & 57 \\
\hline 30 & .....do.. & 8.00 & .... do & 10. & 10.9 & 7. & 15 & 125 & 27 \\
\hline 31 & d & 9.00 & .....d & 6. & 13.0 & 18.0 & 13 & 288 & 42 \\
\hline 51 & $d 0$ & 7.00 & d & 1. & 14.5 & 13.7 & 10 & 219 & 32 \\
\hline 57 & ..do... & 10.00 & do & 7. & 20.4 & 11.1 & 19 & 178 & 37 \\
\hline 5 & do & 8.00 & ...d & 8. & 19 & & 19 & 131 & 32 \\
\hline 62 & do & 9.00 & ....d d & 12.0 & 22.5 & 13.0 & 24 & 208 & 450 \\
\hline 90 & Nov. 22,1910 & 8.00 & $\ldots$. d & 2.6 & 27.8 & 35.7 & 21 & 571 & 784 \\
\hline 91 & .....do... & 9.50 & ... d d & 10. & 11.6 & 19. & 15 & 312 & 46 \\
\hline 92 & .....do.. & 8.00 & 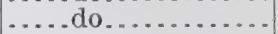 & 18.3 & 16.1 & 34 . & 24 & 556 & 79 \\
\hline 94 & d & 9. & 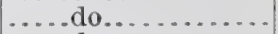 & .0 & 24.5 & 6. & 17 & 104 & 27 \\
\hline 95 & $.40 .$. & 10.00 & $\ldots d$ & 4. & 8.9 & 12. & 9 & 205 & 29 \\
\hline 100 & . & 9.50 & & 1. & 3.2 & 17. & 2 & 286 & 31 \\
\hline & d & 8. & $\ldots$ & 10. & 17.7 & & 19 & & 68 \\
\hline 10 &.$d$ & 9.50 & ... & 14. & 18.4 & 15.2 & 23 & 243 & 475 \\
\hline 106 &.$d$ & 7.50 & & 15.6 & 22.8 & 22. & 26 & 365 & 63 \\
\hline 24 & Nov. 21,1910 & 6.50 & ...d & 15.0 & 61.0 & 27.0 & 53 & 432 & 96 \\
\hline 25 & .... do......... & 6.00 & d & 5.1 & 29.0 & 31.0 & 23 & 495 & 73 \\
\hline 26 & .....do... & 9.00 & & 5. & 47.5 & 22. & 36 & 352 & 71 \\
\hline 105 & Nov. 22,1910 & & $\ldots . . . \mathrm{do}$ & 5.5 & 14.2 & 33.4 & 13 & 535 & 673 \\
\hline 21 & Nov. 21,1910 & 9.00 & $\ldots . . d$ & .0 & 7.5 & 12.0 & 5 & 192 & 244 \\
\hline 22 & .....do... & 8.00 & ..... do & 3.0 & 45.0 & 29.5 & 330 & 474 & 81 \\
\hline 23 & do.. & 9.00 & ......do & 4.0 & 8.0 & 12.5 & 84 & 200 & 284 \\
\hline 104 & Nov. 22,1910 & 8.00 & $\ldots . \mathrm{dc}$ & .0 & 9.6 & 32. & 67 & 522 & 589 \\
\hline 103 & ..do... & 8.50 & ..... do & 5.9 & 11.8 & 12.7 & 124 & 203 & 327 \\
\hline 20 & Nov. 21,1910 & 8.00 & ..... do & .4 & 17.0 & 14.0 & 12 & 224 & 347 \\
\hline 18 & .....do......... & 9.00 & .....do do & 7.5 & 30.5 & 34.0 & 266 & 542 & 808 \\
\hline
\end{tabular}


Details of Examination of Buoy Reef-Continued.

\begin{tabular}{|c|c|c|c|c|c|c|c|c|c|}
\hline \multirow{2}{*}{$\begin{array}{l}\text { Angle } \\
\text { No. }\end{array}$} & \multirow{2}{*}{$\begin{array}{c}\text { Date of } \\
\text { examination. }\end{array}$} & \multirow{2}{*}{$\begin{array}{l}\text { Depth } \\
\text { of } \\
\text { water. }\end{array}$} & \multirow{2}{*}{ Character of growth. } & \multicolumn{3}{|c|}{$\begin{array}{l}\text { Oysters caught per } \\
\text { square yard. }\end{array}$} & \multicolumn{3}{|c|}{$\begin{array}{l}\text { Estimated quantity oys- } \\
\text { ters per acre. }\end{array}$} \\
\hline & & & & Spat. & Culls. & Counts. & Seed. & Market. & Total. \\
\hline & & Fcet. & & & & & Bush. & Bush. & Bush. \\
\hline 17 & Nov 21,1910 & $\begin{array}{l}8.00 \\
8.00\end{array}$ & $\begin{array}{l}\text { Dense } \\
\ldots . . . \text { do }\end{array}$ & $\begin{array}{l}3.4 \\
2.5\end{array}$ & $\begin{array}{r}29.7 \\
9.0\end{array}$ & $\begin{array}{l}9.4 \\
9.9\end{array}$ & $\begin{array}{r}232 \\
81\end{array}$ & $\begin{array}{l}150 \\
158\end{array}$ & $\begin{array}{l}382 \\
239\end{array}$ \\
\hline $6 t^{\circ}$ & Nov. 22,1910 & 8. 00 & .....do. & 1.3 & 13.0 & 8. & 100 & 139 & 239 \\
\hline 67 & .....do......... & 8.00 & do. & 4.4 & 21.8 & 27.4 & 183 & 438 & 621 \\
\hline 47 & Nov. 21,1910 & 10.00 & Scatterin & 4.5 & 15.0 & 8.9 & 136 & 142 & 278 \\
\hline 48 & .....do......... & 9.00 & .....do. & 5.0 & 14.0 & & & & 213 \\
\hline 54 & .. do.... & 8.00 & do. & 13.5 & 9.1 & 5. & 35 & 91 & 249 \\
\hline 49 & do.. & 10.00 & do & 2.8 & 6.1 & 5. & 6 & 0 & 142 \\
\hline 50 & ..do. & 8.00 & do. & 14. & 33.0 & & 33 & 145 & 480 \\
\hline 37 & do.. & 7.50 & Very scattering. & 5.6 & 3.6 & 2. & 6 & 45 & 109 \\
\hline 99 & Nov. 22,1910 & 7.00 & .....do... & 8.9 & 10.0 & 6. & 13 & 101 & 233 \\
\hline 93 & ..... do... & 9.00 & do. & 6.0 & 13.0 & 3.5 & 133 & 56 & 189 \\
\hline 15 & Nov. 21,1910 & 9.00 & do. & .0 & .0 & 4. & 0 & 64 & 64 \\
\hline 19 & .....do.... & 000 & & .0 & 2.5 & 2. & 17 & 32 & 49 \\
\hline 78 & Nov. 22,1910 & 10.00 & do & 6.7 & 8.9 & 4.5 & 109 & 72 & 181 \\
\hline 28 & Nov. 21,1910 & 10.00 & Deplet & .0 & 1.2 & .0 & 8 & 0 & \\
\hline 89 & 22,19 & 10.00 & .....d & .0 & .0 & .8 & 0 & 0 & \\
\hline 59 & Nov. 21,1910 & 11.00 & .. do & .0 & .0 & .0 & 0 & 0 & 0 \\
\hline 60 & .....do......... & 11.00 & 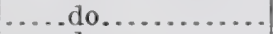 & 7.3 & 6.0 & .0 & 93 & 0 & 93 \\
\hline 61 & .....do & 10.00 & $\ldots d$ & 7.8 & 7.2 & 1.1 & 105 & 18 & 123 \\
\hline 107 & Nov. 22,1910 & 10.00 & $\ldots d$ & .0 & .0 & 0 & 0 & 0 & 0 \\
\hline 44 & Nov. 21,1910 & 12.00 & . do & .0 & .0 & .7 & 0 & 11 & 11 \\
\hline
\end{tabular}

CEDAR POINT REEF.

This is a long, narrow bed extending from the end of Cedar Point for a distance of about $1 \frac{1}{2}$ miles toward the wreck buoy. It is now connected with the southernmost bed of Buoy Reef by a very scattering growth lying on what was comparatively recently barren bottom, the original zone of separation being indicated by a narrow gully carrying $8 \frac{1}{2}$ feet of water lying between depths of about 6 feet on the adjacent parts of the two reefs. It is probable that this very scattering growth is the artificial product of dredging operations.

The area, density of growth, and estimated content of small and market oysters are shown in the following table:

Oyster Growth on Cedar Point Reef.

\begin{tabular}{|c|c|c|c|c|c|c|}
\hline \multirow{2}{*}{ Character of oyster growth. } & \multirow{2}{*}{ Area. } & \multicolumn{2}{|c|}{ Oysters per acre. } & \multicolumn{3}{|c|}{ Estimated content of oysters. } \\
\hline & & $\begin{array}{l}\text { Under } 3 \\
\text { inches. }\end{array}$ & $\begin{array}{l}\text { Over } 3 \\
\text { inches. }\end{array}$ & Seed. & Market. & Total. \\
\hline $\begin{array}{l}\text { Dense............. } \\
\text { Seattering. } \\
\text { Very scattering . . } \\
\text { Depleted........ }\end{array}$ & $\begin{array}{r}\text { Acres. } \\
100 \\
21 \\
24 \\
56\end{array}$ & $\begin{array}{r}\text { Bushels. } \\
140 \\
121 \\
36 \\
89\end{array}$ & $\begin{array}{r}\text { Bushels. } \\
340 \\
130 \\
41 \\
0\end{array}$ & $\begin{array}{r}\text { Bushels. } \\
14,000 \\
2,541 \\
864 \\
4,984\end{array}$ & $\begin{array}{r}\text { Bushels. } \\
34,000 \\
2,730 \\
984 \\
0\end{array}$ & $\begin{array}{r}\text { Bushels. } \\
48,000 \\
5,271 \\
1,848 \\
4,984\end{array}$ \\
\hline Total.. & 201 & & & 22,389 & 37,714 & 60,103 \\
\hline
\end{tabular}

The reef consists of a narrow ridge of very dense growth extending from the gully above mentioned, flanked by scattering and very scattering growths along the southern edge of its offshore half and on the northern edge of its inshore half by a fringe which gradually

$65397^{\circ}-13 \longrightarrow 2$ 
decreases shoreward from a scattering growth to a depleted area which extends to low-water mark. For the outermost mile of its length the reef is hardly more than 200 yards in width and the dense growth averages about 100 yards wide. Within a half mile of shore the dense area expands and curves southward to connect with the corresponding area of Pass des Huitres bed. The proportion of market oysters to small ones is generally high throughout this dense area and is relatively much lower on the less densely populated bottoms.

As has been already stated, the scattering and very scattering growths occur as fringes along the edges of the dense growth. The depleted area expands on the shoreward part of the reef, extending from the dense growth to the shore, as widely scattered clusters of small oysters lying on the sand. These clusters lie in very shoal water, and although the growth was not examined with care, it apparently extends for some distance northward from the end of Cedar Point.

The depth of water lying over Cedar Point Reef varies from $6 \frac{1}{2}$ feet at its outer end to less than 2 feet at the inner edge of the area of dense growth. The surrounding water is generally about 2 feet deeper than over adjacent parts of the reef.

The following table shows in detail the results of the examinations made on the bed:

Details of Examination of Cedar Point Reef.

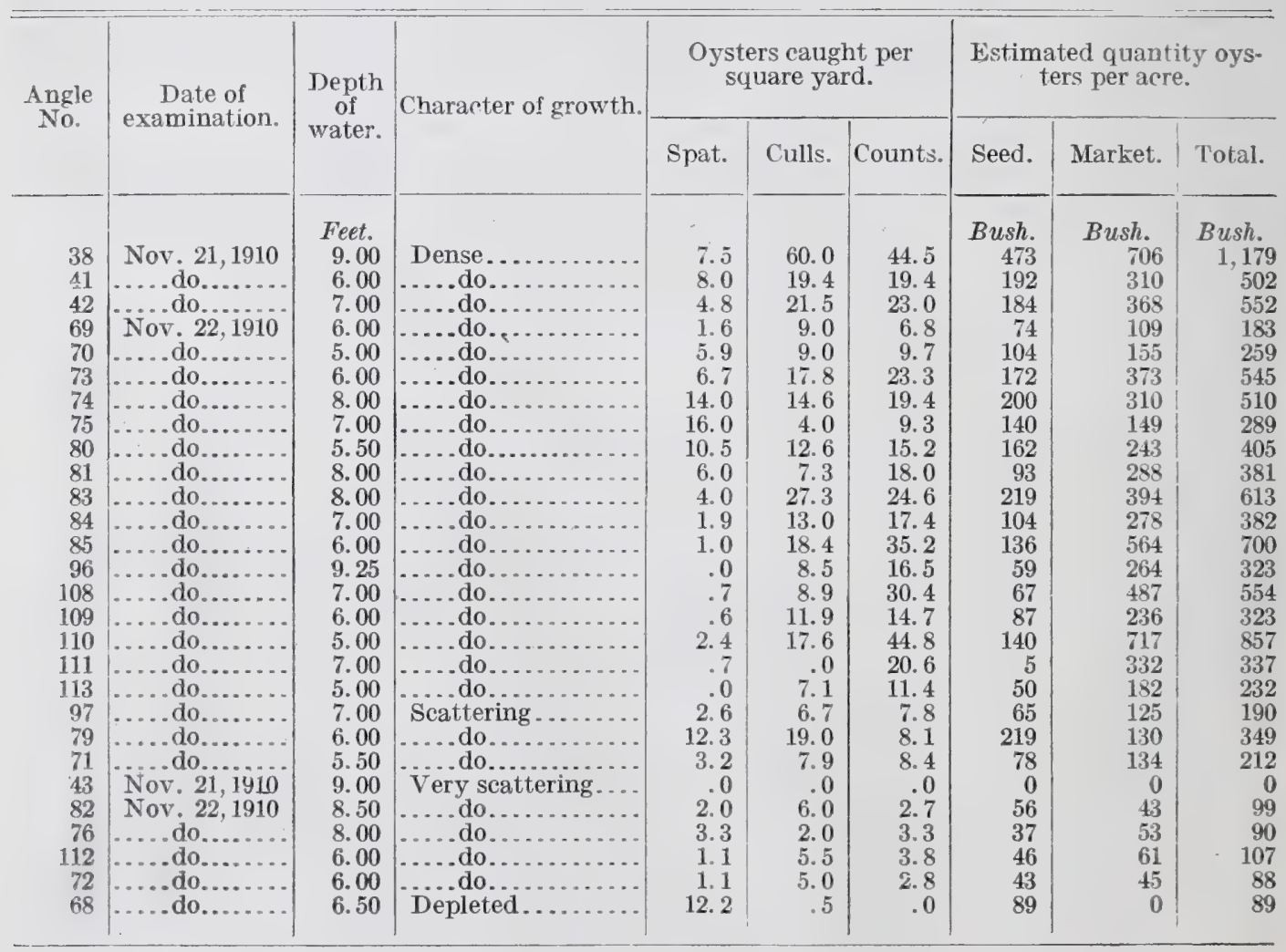


PASS DES HUITRES BED.

This is a bed of indeterminate boundaries, being continuous with Cedar Point bed on the north and on the south with Pass des Huitres Flats and the whole series of beds extending to Dauphin Island Bay inside of Grants Pass and as far as Pass Drury in Mobile Bay. The names applied by the oystermen to the beds in the vicinity of Grants Pass designate general localities rather than defined beds, and for the purposes of this report their boundaries have been arbitrarilly selected and are not definitely indicated on the chart. For this reason the areas assigned to the several beds may differ somewhat from those which would be regarded by others as proper, but as the excess or deficiency of one bed is compensated for by decreasing or increasing its neighbors, the total area of all of the beds, which is the important fact, is not affected. Pass des Huitres bed takes its name from a channel having about 13 feet in its deepest part and shoaling to 4 feet or less at each end, which sweeps in a curve about 350 yards off the end of Cedar Point. Its area and the conditions of its oyster growth are shown in the following table:

Oyster Growth on Pass des Huitres Bet.

\begin{tabular}{|c|c|c|c|c|c|c|}
\hline \multirow{2}{*}{ Character of oyster growth. } & \multirow{2}{*}{ Area. } & \multicolumn{2}{|c|}{ Oysters per acre. } & \multicolumn{3}{|c|}{ Estimated content of oysters. } \\
\hline & & $\begin{array}{l}\text { Under } 3 \\
\text { inches. }\end{array}$ & $\begin{array}{l}\text { Over } 3 \\
\text { inches. }\end{array}$ & Seed. & Market. & Total. \\
\hline $\begin{array}{l}\text { Dense...... } \\
\text { Scattering.. }\end{array}$ & $\begin{array}{r}\text { A cres. } \\
53 \\
30\end{array}$ & $\begin{array}{r}\text { Bushels. } \\
365 \\
213\end{array}$ & $\begin{array}{r}\text { Bushels. } \\
303 \\
92\end{array}$ & $\begin{array}{r}\text { Bushels. } \\
19,345 \\
6,390\end{array}$ & $\begin{array}{r}\text { Bushels, } \\
16,059 \\
2,760\end{array}$ & $\begin{array}{r}\text { Bushels. } \\
35,404 \\
9,150\end{array}$ \\
\hline Total.. & 83 & & $\ldots$ & 25,735 & 18,819 & 44,554 \\
\hline
\end{tabular}

The dense growth lies principally south and east of the channel, though some of the bottom most prolific of market oysters is in the deepest water. Most of the marketable oysters are between 3 and 4 inches long, but in the deeper water the proportion of larger ones is greater than elsewhere. There is a good ratio of single oysters and small clusters on this bed and the shape is therefore better than on the beds previously described. The quality at the time of examination was fair.

The scattering growth lies north of the channel on the edge of the barren bottom extending to Cedar Point. The oysters on this area of hard sand and shell bottom are nearly all single or in small clusters. There were, in December, 1910, practically no oysters over 4 inches in length and a great abundance of individuals less than 3 inches long. 
The following table exhibits the dat a obtained from the examination made of this bed:

Detalls of Examination of Pass des Huitres Bed.

\begin{tabular}{|c|c|c|c|c|c|c|c|c|c|}
\hline \multirow{2}{*}{$\begin{array}{l}\text { Angle } \\
\text { No. }\end{array}$} & \multirow{2}{*}{$\begin{array}{c}\text { Date of } \\
\text { examination. }\end{array}$} & \multirow{2}{*}{$\begin{array}{l}\text { Depth } \\
\text { of } \\
\text { water. }\end{array}$} & \multirow{2}{*}{ Character of growth. } & \multicolumn{3}{|c|}{$\begin{array}{l}\text { Oysters caught per } \\
\text { square yard. }\end{array}$} & \multicolumn{3}{|c|}{$\begin{array}{l}\text { Estimated quantity oys- } \\
\text { ters per acre. }\end{array}$} \\
\hline & & & & Spat. & Culls. & Counts. & Seed. & Market. & Total. \\
\hline $\begin{array}{l}445 \\
446 \\
447 \\
449 \\
496 \\
497 \\
530 \\
531 \\
448 \\
450 \\
451 \\
532\end{array}$ & 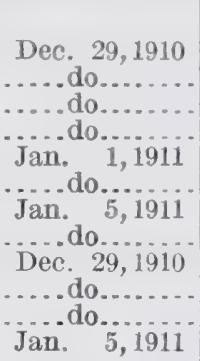 & $\begin{array}{r}\text { Feet. } \\
3.50 \\
4.00 \\
5.00 \\
5.00 \\
2.00 \\
2.50 \\
11.00 \\
13.00 \\
4.00 \\
5.00 \\
4.00 \\
7.00\end{array}$ & 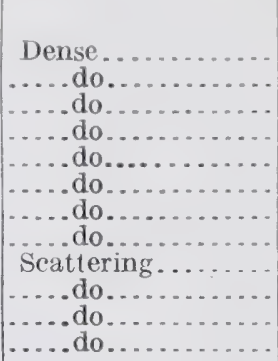 & $\begin{array}{r}1.8 \\
15.7 \\
.0 \\
2.0 \\
.0 \\
4.1 \\
4.5 \\
5.5 \\
2.5 \\
3.5 \\
4.8\end{array}$ & $\begin{array}{l}31.8 \\
30.0 \\
77.5 \\
71.3 \\
33.5 \\
48.8 \\
65.7 \\
30.9 \\
13.0 \\
33.2 \\
40.1 \\
19.2\end{array}$ & $\begin{array}{r}6.4 \\
18.0 \\
20.6 \\
23.2 \\
17.5 \\
18.9 \\
25.0 \\
21.8 \\
6.5 \\
5.0 \\
7.5 \\
4.0\end{array}$ & $\begin{array}{r}\text { Bush. } \\
235 \\
210 \\
654 \\
499 \\
249 \\
342 \\
486 \\
248 \\
129 \\
250 \\
305 \\
168\end{array}$ & $\begin{array}{r}\text { Bush. } \\
104 \\
288 \\
330 \\
372 \\
280 \\
302 \\
400 \\
350 \\
104 \\
80 \\
120 \\
64\end{array}$ & $\begin{array}{r}\text { Bush. } \\
339 \\
498 \\
984 \\
871 \\
529 \\
644 \\
886 \\
598 \\
233 \\
330 \\
425 \\
232\end{array}$ \\
\hline
\end{tabular}

PASS DES HUITRES FLATS.

This bed, contiguous with the preceding and the following, lies on the shallow flats south of Pass des Huitres, where the depth at low water ranges from 6 inches to 2 feet, excepting on the western side, where a depth of 5 feet is found on the edge of the area of very scattering growth.

The area, density of growth, and total content of oysters on the bed as arbitrarily defined in this report are shown in the following table:

Oyster Growth on Pass des Huttres Flats.

\begin{tabular}{|c|c|c|c|c|c|c|}
\hline \multirow{2}{*}{ Character of oyster growth. } & \multirow{2}{*}{ Area. } & \multicolumn{2}{|c|}{ Oysters per acre. } & \multicolumn{3}{|c|}{ Estimated content of oysters. } \\
\hline & & $\begin{array}{l}\text { Under } 3 \\
\text { inches. }\end{array}$ & $\begin{array}{l}\text { Over } 3 \\
\text { inches. }\end{array}$ & Seed. & Market. & Total. \\
\hline $\begin{array}{l}\text { Dense............. } \\
\text { Scattering........ } \\
\text { Very scattering. }\end{array}$ & $\begin{array}{r}\text { Acres. } \\
122 \\
41 \\
39\end{array}$ & $\begin{array}{r}\text { Bushels. } \\
296 \\
131 \\
26\end{array}$ & $\begin{array}{r}\text { Bushels. } \\
304 \\
139 \\
46\end{array}$ & $\begin{array}{r}\text { Bushels. } \\
36,112 \\
5,371 \\
1,014\end{array}$ & $\begin{array}{r}\text { Bushels. } \\
37,088 \\
5,699 \\
1,794\end{array}$ & $\begin{array}{r}\text { Bushels. } \\
73,200 \\
11,070 \\
2,808\end{array}$ \\
\hline Total... & 202 & 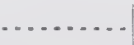 & & 42,497 & 44,581 & 87,078 \\
\hline
\end{tabular}

The dense growth lies in the part of the bed toward Mobile Bay, where it commences as a sharply defined ridge rising abruptly from a depth of about 3 feet over the mud to about 1 foot near the edge of the oysters. The eastern part of the dense area is composed of a mass of shells, but in the western part there are some sandy areas covering a shelly substratum.

The scattering growth merges with the western edge of the dense area where the water begins to deepen, and this in turn passes gradually to an area of very scattering oysters lying on soft mud in which 
are many buried shells. The majority of the oysters on this part of the bed are large, over 4 inches in length, while elsewhere, particularly on the dense growth, there are comparatively few such oysters, and most of the smaller ones, both market oysters and culls, are in large closely compacted clusters.

The data gathered by the several examinations on this bed are as follows:

Detalls of Examination of Pass des Huitres Flats.

\begin{tabular}{|c|c|c|c|c|c|c|c|c|c|}
\hline \multirow{2}{*}{$\begin{array}{l}\text { Angle } \\
\text { No. }\end{array}$} & \multirow{2}{*}{$\begin{array}{l}\text { Date of } \\
\text { examination. }\end{array}$} & \multirow{2}{*}{$\begin{array}{l}\text { Depth } \\
\text { of } \\
\text { water. }\end{array}$} & \multirow{2}{*}{ Character of growth. } & \multicolumn{3}{|c|}{$\begin{array}{l}\text { Oysters caught per } \\
\text { square yard. }\end{array}$} & \multicolumn{3}{|c|}{$\begin{array}{l}\text { Estimated quantity oys- } \\
\text { ters per acre. }\end{array}$} \\
\hline & & & & Spat. & Culls. & Counts. & Seed. & Market. & Total. \\
\hline & & Feet. & & & & & Bush. & Bush, & Bush. \\
\hline $\begin{array}{l}442 \\
443\end{array}$ & Dee. 29,191 & $\begin{array}{l}3.00 \\
3.00\end{array}$ & De...do & $\begin{array}{l}0.5 \\
2.5\end{array}$ & 45.4 & 13.7 & $\begin{array}{l}295 \\
346\end{array}$ & $\begin{array}{l}299 \\
219\end{array}$ & $\begin{array}{l}594 \\
565\end{array}$ \\
\hline 444 & ..... do... & 3.00 & do. & 10.0 & 45.4 & 17. & 388 & 274 & 662 \\
\hline 452 & do... & 5.50 & do. & 2.7 & 10 & 10 & 8 & 160 & 249 \\
\hline 489 & Jan. 1,1911 & 1.80 & do. & 3.5 & 55.5 & 42.0 & 414 & 672 & 1,086 \\
\hline 490 & .....do......... & 2.20 & do & .0 & 8.0 & 6. & 5 & 96 & 152 \\
\hline 491 & . do...... & 2.50 & do. & 7.2 & 34.2 & 23. & 29 & 372 & 66 \\
\hline 49 & do... & 1.40 & do.. & 3.6 & 30 . & 11. & 23 & 182 & 421 \\
\hline & $d$ & 2.10 & do. & .0 & 67. & 38. & 47 & 604 & 1,077 \\
\hline 49 & do & 2.00 & . do & .0 & 29.0 & 11.5 & 20 & 183 & 386 \\
\hline 49 & $\ldots$ & 2.40 & d & 5.0 & 61.7 & 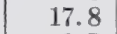 & 46 & & 751 \\
\hline 48 & do... & 2.80 & Scattering.... & .6 & 18. 1 & 8.7 & 131 & 139 & 270 \\
\hline 453 & Dec. 29,1911 & 6.00 & Very scattering.... & .0 & 3.6 & 2.9 & 26 & 46 & 72 \\
\hline
\end{tabular}

\section{DUTCH GULLY.}

Dutch Gully bed lies in and about an area of slightly deeper water between Pass des Huitres Flats on the north and Big Gully and Dutch Island beds on the south. The depth of the water ranges from about 6 inches to 3 or 4 feet, the latter depth lying on the area of scattering growth. Although this bed, like the others in the vicinity, is without well defined boundaries, it is assumed in this report to have approximately the following area, density of growth, and oyster content:

Oyster Growth on Dutch Gully Bed.

\begin{tabular}{|c|c|c|c|c|c|c|}
\hline \multirow{2}{*}{ Character of oyster growth. } & \multirow{2}{*}{ Area. } & \multicolumn{2}{|c|}{ Oysters per acre. } & \multicolumn{3}{|c|}{ Estimated content of oysters. } \\
\hline & & $\begin{array}{l}\text { Under } 3 \\
\text { inches. }\end{array}$ & $\begin{array}{l}\text { Over } 3 \\
\text { inches. }\end{array}$ & Seed. & Market. & Total. \\
\hline $\begin{array}{l}\text { Dense....... } \\
\text { Scattering.. }\end{array}$ & $\begin{array}{r}\text { Acres. } \\
39 \\
19\end{array}$ & $\begin{array}{r}\text { Bushels. } \\
206 \\
222\end{array}$ & $\begin{array}{r}\text { Bushels. } \\
253 \\
101\end{array}$ & $\begin{array}{r}\text { Bushels. } \\
8,034 \\
4,218\end{array}$ & $\begin{array}{r}\text { Bushels. } \\
9,867 \\
1,919\end{array}$ & $\begin{array}{r}\text { Bushels. } \\
17,901 \\
6,137\end{array}$ \\
\hline Total.. & 58 & & & 12,252 & 11,786 & 24,038 \\
\hline
\end{tabular}

The dense growth, which lies principally in a depth of less than $2 \frac{1}{2}$ feet, occupies the central part of the bed. The clusters generally are small with a considerable proportion of single oysters. The 
market oyteris aro of medium size, most of them being botween 3 and 4 inches long with a few of greater length. The voung growth is prolific. The areas of scattering growth are two, lying respectively to the east and wost of the dense growth in slightly deeper water. In these areas the oysters are generally in clusters, lying on a hard bottom. The voung growth is slightly more abundant than on the denser portions of the bed.

The following table expresses the details of the several examinations made on the bed:

Detalls of Examination of Dutch Gully.

\begin{tabular}{|c|c|c|c|c|c|c|c|c|c|}
\hline \multirow{2}{*}{$\begin{array}{l}\text { Angle } \\
\text { No. }\end{array}$} & \multirow{2}{*}{$\begin{array}{l}\text { Date of } \\
\text { examination. }\end{array}$} & \multirow{2}{*}{$\begin{array}{l}\text { Depth } \\
\text { of } \\
\text { water. }\end{array}$} & \multirow{2}{*}{ Character of growth. } & \multicolumn{3}{|c|}{$\begin{array}{l}\text { Oysters caught per } \\
\text { square yard. }\end{array}$} & \multicolumn{3}{|c|}{$\begin{array}{l}\text { Estimated quantity oys- } \\
\text { tars per acre. }\end{array}$} \\
\hline & & & & Spat. & Culls. & Counts. & Seed. & Market. & Total. \\
\hline $\begin{array}{l}475 \\
476 \\
477 \\
485 \\
487\end{array}$ & \begin{tabular}{l} 
Dec. 31,1910 \\
\hdashline$\ldots$ do \\
\hdashline$\ldots$ do \\
\hdashline$\ldots$ do \\
$\ldots$ do
\end{tabular} & $\begin{array}{r}\text { Feet. } \\
1.8 \\
1.0 \\
2.8 \\
4.3 \\
1.0\end{array}$ & 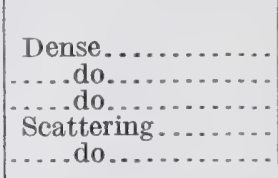 & $\begin{array}{l}2.3 \\
1.3 \\
.8 \\
2.3 \\
9.6\end{array}$ & $\begin{array}{l}31.3 \\
23.3 \\
22.2 \\
33.1 \\
18.3\end{array}$ & $\begin{array}{r}15.3 \\
16.8 \\
15.4 \\
8.5 \\
4.2\end{array}$ & $\begin{array}{r}\text { Bush. } \\
235 \\
172 \\
211 \\
248 \\
196\end{array}$ & $\begin{array}{r}\text { Bush. } \\
245 \\
269 \\
246 \\
136 \\
67\end{array}$ & $\begin{array}{r}\text { Bush. } \\
480 \\
441 \\
457 \\
384 \\
263\end{array}$ \\
\hline
\end{tabular}

WEST SIDE OF DUTCH ISLAND.

Dutch Islare is a small shell bank called Gull Island on the Coast Survey charts. The oyster bed designated by the name used above extends from the western edge of the island to barren bottom, between Dutch Guily and Peter Billy's Gully.

The following table exhibits in summary the data relating to this bed:

Orgiter Growth on West Side of Dutch Island.

\begin{tabular}{|c|c|c|c|c|c|c|}
\hline \multirow{2}{*}{ Character of oyster growth. } & \multirow{2}{*}{ Area. } & \multicolumn{2}{|c|}{ Oysters per acre. } & \multicolumn{3}{|c|}{ Estimated content of oysters. } \\
\hline & & $\begin{array}{l}\text { Under } 3 \\
\text { inches. }\end{array}$ & $\begin{array}{c}\text { Over } 3 \\
\text { inches. }\end{array}$ & Seed. & Market. & Total. \\
\hline $\begin{array}{l}\text { Dense....... } \\
\text { Scattering... } \\
\text { Depleted... }\end{array}$ & $\begin{array}{r}\text { Acres. } \\
42 \\
21 \\
24\end{array}$ & $\begin{array}{r}\text { Bushels. } \\
322 \\
298 \\
165\end{array}$ & $\begin{array}{r}\text { Bushels. } \\
279 \\
99 \\
13\end{array}$ & $\begin{array}{r}\text { Bushels. } \\
13,524 \\
6,258 \\
3,960\end{array}$ & $\begin{array}{r}\text { Bushels. } \\
11,718 \\
2,079 \\
312\end{array}$ & $\begin{array}{r}\text { Bushels. } \\
25,242 \\
8,337 \\
4,272\end{array}$ \\
\hline Total.. & 87 & 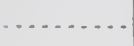 & $\ldots$ & 23,742 & 14,109 & 37,851 \\
\hline
\end{tabular}

Close to Duteh Island there is an area of hard shelly bottom with a growth of densely clustered irregular-shaped small oysters, practically devoid of market stock. Over most of this area the water is very shallow, reaching a maximum of 2 feet. To the westward of this is an area of dense growth, most of which lies in water from 2 to 4 feet deep, with a maximum of about 5 feet at its western edge. On this part of the bed there are few oysters over 4 inches long, most of 
the so-called market stock being between 3 and 4 inches in length and growing in heavy clusters. The scattering growth lies in a zone between the dense growth and the soft muddy bottom of Mississippi Sound in an average depth of water of about 5 feet. Practically none of the oysters of marketable size are over 4 inches long. On both this area and on the bottom covered with dense growth young oysters are abundant, varying from 180 to 546 bushels per acre, with an average density of over 300 bushels per acre.

The following data state the results of the examinations made on this bed:

Detalls of Examination of Dutch Island.

\begin{tabular}{|c|c|c|c|c|c|c|c|c|c|}
\hline \multirow{2}{*}{$\begin{array}{l}\text { Angle } \\
\text { No. }\end{array}$} & \multirow{2}{*}{$\begin{array}{l}\text { Date of } \\
\text { examination. }\end{array}$} & \multirow{2}{*}{$\begin{array}{l}\text { Depth } \\
\text { of } \\
\text { water. }\end{array}$} & \multirow{2}{*}{ Character of growth. } & \multicolumn{3}{|c|}{$\begin{array}{l}\text { Oysters caught per } \\
\text { square yard. }\end{array}$} & \multicolumn{3}{|c|}{$\begin{array}{l}\text { Estimated quantity oys- } \\
\text { ters per acre. }\end{array}$} \\
\hline & & & & Spat. & Culls. & Counts. & Seed. & Market. & Total. \\
\hline $\begin{array}{l}436 \\
437 \\
438 \\
473 \\
474 \\
433 \\
439 \\
472\end{array}$ & $\begin{array}{c}\text { Dec. } 29,1910 \\
\ldots \ldots \text { do......... } \\
\text { Dec. } 31,1910 \\
\ldots \ldots \text { do ........ } \\
\text { Dec. } 29,1910 \\
\text { De. do. } 31,1910\end{array}$ & $\begin{array}{l}\text { Feet. } \\
4.50 \\
4.00 \\
5.00 \\
1.00 \\
3.00 \\
5.00 \\
5.00 \\
3.00\end{array}$ & $\begin{array}{l}\text { Scattering. } \\
\text { Depleted.... }\end{array}$ & $\begin{array}{l}4.4 \\
.5 \\
5.6 \\
3.6 \\
2.5 \\
6.2 \\
9.4 \\
4.2\end{array}$ & $\begin{array}{l}53.8 \\
25.5 \\
72.5 \\
28.4 \\
33.4 \\
44.5 \\
25.0 \\
19.4\end{array}$ & $\begin{array}{r}17.4 \\
12.5 \\
29.4 \\
16.9 \\
14.2 \\
5.6 \\
6.8 \\
.8\end{array}$ & $\begin{array}{r}\text { Bush. } \\
408 \\
182 \\
546 \\
224 \\
252 \\
355 \\
241 \\
165\end{array}$ & $\begin{array}{r}\text { Bush. } \\
228 \\
200 \\
470 \\
270 \\
227 \\
88 \\
109 \\
13\end{array}$ & $\begin{array}{r}\text { Bush. } \\
636 \\
382 \\
1,016 \\
494 \\
479 \\
443 \\
350 \\
178\end{array}$ \\
\hline
\end{tabular}

BIG GULLY.

This bed, which it is understood is also known as Grants Pass Gully, lies between the dolphin, or cluster of piles marking the eastern entrance to Grants Pass, and Dutch and Grant Islands. The depth of water varies from 9 or 10 feet close to the dolphin to less than 1 foot near the island.

The area of density of growth and total content of small and marketable oysters are shown in the following table:

Oyster Growth on Big Gully Bed.

\begin{tabular}{|c|c|c|c|c|c|c|c|}
\hline \multirow{2}{*}{\multicolumn{2}{|c|}{ - Character of oyster growth. }} & \multirow{2}{*}{ Area. } & \multicolumn{2}{|c|}{ Oysters per acre. } & \multicolumn{3}{|c|}{ Estimated content of oysters. } \\
\hline & & & $\begin{array}{l}\text { Under } 3 \\
\text { inches. }\end{array}$ & $\begin{array}{l}\text { Over } 3 \\
\text { inches. }\end{array}$ & Seed. & Market. & Total. \\
\hline \multirow{2}{*}{\multicolumn{2}{|c|}{ 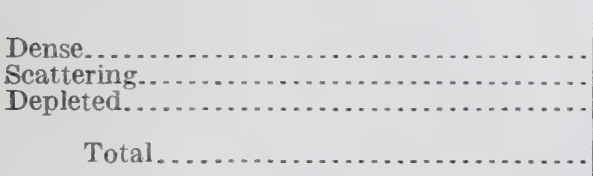 }} & $\begin{array}{r}\text { Acres. } \\
44 \\
10 \\
11\end{array}$ & $\begin{array}{r}\text { Bushels. } \\
284 \\
277 \\
0\end{array}$ & $\begin{array}{r}\text { Bushels. } \\
310 \\
80 \\
0\end{array}$ & $\begin{array}{r}\text { Bushels. } \\
12,496 \\
2,770 \\
0\end{array}$ & $\begin{array}{r}\text { Bushels. } \\
13,640 \\
800 \\
0\end{array}$ & $\begin{array}{r}\text { Bushels. } \\
26,136 \\
3,570 \\
0\end{array}$ \\
\hline & & 65 & .. & ............ & 15,266 & 14,440 & 29,706 \\
\hline
\end{tabular}

In the deeper water close to the dolphin and for a distance of 200 or 300 yards west and northwest in the area indicated as "depleted" on the chart, there are practically no oysters, either large or small, the bottom being composed in large part of soft mud with buried 
shells. The area of scattering crowth lies south and west of this in a depth of water between 1 and 5 feet. Although this part of the bed bear's but about one-fourth as many market oysters per acre as are found on the dense area, there are practically as many small ones. The bottom bearing the dense growth of market oysters lies between that just described and Dutch and Grant Islands, its western limit being defined by the very shallow water extending from Dutch toward Grant Pass. The depth of the water ranges from about 1 to is feet and the market oysters vary in quantity from 160 to upward of 600 bushels per acre. The densest growth ocrurs north of Grant Island, and on the steps lying between that point and Gull Island there is a large proportion of single oysters, a considerable number of them being large.

The foregoing description is based in part on the data shown in the following table:

Details of Examination of Big Gully (Grants Pass Gully).

\begin{tabular}{|c|c|c|c|c|c|c|c|c|c|}
\hline \multirow{2}{*}{$\begin{array}{l}\text { Angle } \\
\text { No. }\end{array}$} & \multirow{2}{*}{$\begin{array}{l}\text { Date of } \\
\text { examination. }\end{array}$} & \multirow{2}{*}{$\begin{array}{l}\text { Depth } \\
\text { of } \\
\text { water. }\end{array}$} & \multirow{2}{*}{ Character of growth. } & \multicolumn{3}{|c|}{$\begin{array}{l}\text { Oysters caught per } \\
\text { square yard. }\end{array}$} & \multicolumn{3}{|c|}{$\begin{array}{l}\text { Estimated quantity oys- } \\
\text { ters per acre. }\end{array}$} \\
\hline & & & & Spat. & Culls. & Counts. & Seed. & Market. & Total. \\
\hline $\begin{array}{l}478 \\
480 \\
482 \\
484 \\
483 \\
479\end{array}$ & 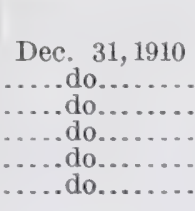 & $\begin{array}{r}\text { Feet. } \\
5.0 \\
5.0 \\
2.0 \\
1.6 \\
1.2 \\
7.0\end{array}$ & 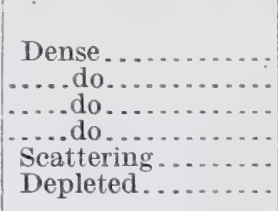 & $\begin{array}{r}0.6 \\
3.1 \\
1.0 \\
4.1 \\
1.2 \\
.0\end{array}$ & $\begin{array}{r}30.0 \\
27.4 \\
50.0 \\
46.0 \\
38.4 \\
.0\end{array}$ & $\begin{array}{r}19.4 \\
10.0 \\
38.0 \\
10.4 \\
5.0 \\
.0\end{array}$ & $\begin{array}{r}\text { Bush. } \\
214 \\
213 \\
357 \\
351 \\
277 \\
0\end{array}$ & $\begin{array}{r}\text { Bush. } \\
311 \\
160 \\
604 \\
166 \\
80 \\
0\end{array}$ & $\begin{array}{r}\text { Bush. } \\
525 \\
373 \\
961 \\
517 \\
357 \\
0\end{array}$ \\
\hline
\end{tabular}

\section{PETER BILLYS GULLY.}

This lies opposite Big Gully and on the west side of the shallow water lying south of Dutch Island. It includes the oysters lying between the bed on the west side of Dutch Island and Grants Pass bed and is continuous with both. Its area, character of orster growth, and contents are shown in the following table:

Oyster Growth in Peter Billys Gully.

\begin{tabular}{|c|c|c|c|c|c|c|}
\hline \multirow{2}{*}{ Character of oyster growth. } & \multirow{2}{*}{ Area. } & \multicolumn{2}{|c|}{ Oysters per acre. } & \multicolumn{3}{|c|}{ Estimated content of oysters. } \\
\hline & & $\begin{array}{l}\text { Under } 3 \\
\text { inches. }\end{array}$ & $\begin{array}{l}\text { Over } 3 \\
\text { inches. }\end{array}$ & Seed. & Market. & Total. \\
\hline $\begin{array}{l}\text { Dense.......... } \\
\text { Very scattering.. } \\
\text { Depleted........ }\end{array}$ & $\begin{array}{r}\text { Acres. } \\
39 \\
14 \\
28\end{array}$ & $\begin{array}{r}\text { Bushels. } \\
324 \\
40 \\
0\end{array}$ & $\begin{array}{r}\text { Bushels. } \\
245 \\
38 \\
6\end{array}$ & $\begin{array}{r}\text { Bushels. } \\
12,636 \\
560 \\
0\end{array}$ & $\begin{array}{r}\text { Bushels. } \\
9,555 \\
532 \\
168\end{array}$ & $\begin{array}{r}\text { Bushels. } \\
22,191 \\
1,092 \\
168\end{array}$ \\
\hline Total... & 81 & 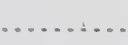 & ... & 13,196 & 10,255 & 23,451 \\
\hline
\end{tabular}


The eastern part of this bed is a small area of very scattering growth lying north of a long shell bank west of Grants Island. It lies in the very shoal water which stretches north to Gull Island, on a deposit of an inch or two of soft mud on a substratum of hard sand and shells. The orsters are small and poor. West of this lies the dense growth covering an area of about 39 acres in a depth of water varying from 1 to 5 feet. This bottom consists of densely compacted sand and shells, with oysters of the raccoon type in clusters. On the western border of this growth there is a depleted area on which there are few oysters of any size. The bottom changes gradually from hard sand and shell close to the dense area to soft mud with buried shells on the western border of the bed.

Detalls of Examination of Peter Billys Gully.

\begin{tabular}{|c|c|c|c|c|c|c|c|c|c|}
\hline \multirow{2}{*}{$\begin{array}{l}\text { Angle } \\
\text { No. }\end{array}$} & \multirow{2}{*}{$\begin{array}{l}\text { Date of } \\
\text { examination. }\end{array}$} & \multirow{2}{*}{$\begin{array}{l}\text { Depth } \\
\text { of } \\
\text { water. }\end{array}$} & \multirow{2}{*}{ Character of growth. } & \multicolumn{3}{|c|}{$\begin{array}{l}\text { Oysters caught per } \\
\text { square yard. }\end{array}$} & \multicolumn{3}{|c|}{$\begin{array}{l}\text { Estimated quantity oys- } \\
\text { ters per acre. }\end{array}$} \\
\hline & & & & Spat. & Culls. & Counts. & Seerl. & Market. & T'otal. \\
\hline $\begin{array}{l}428 \\
431 \\
432 \\
468 \\
470 \\
471 \\
469 \\
430 \\
434\end{array}$ & 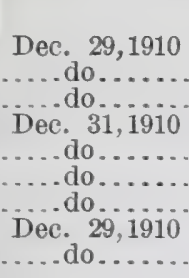 & $\begin{array}{c}\text { Feet. } \\
5.00 \\
4.50 \\
4.00 \\
3.00 \\
1.00 \\
3.00 \\
1.50 \\
5.50 \\
6.00\end{array}$ & 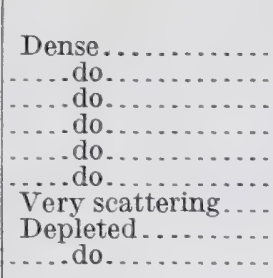 & $\begin{array}{r}5.6 \\
4.4 \\
4.0 \\
1.2 \\
.0 \\
1.7 \\
.0 \\
.0 \\
.0\end{array}$ & $\begin{array}{r}38.7 \\
76.1 \\
58.0 \\
30.4 \\
21.9 \\
35.8 \\
5.7 \\
.0 \\
.0\end{array}$ & $\begin{array}{r}15.6 \\
15.5 \\
26.5 \\
11.2 \\
9.7 \\
13.3 \\
2.4 \\
.7 \\
.0\end{array}$ & $\begin{array}{r}\text { Bush. } \\
310 \\
564 \\
434 \\
221 \\
153 \\
263 \\
40 \\
0 \\
0\end{array}$ & $\begin{array}{r}\text { Bush. } \\
250 \\
248 \\
424 \\
179 \\
155 \\
213 \\
38 \\
11 \\
0\end{array}$ & $\begin{array}{r}\text { Bush. } \\
560 \\
812 \\
858 \\
400 \\
308 \\
476 \\
78 \\
11 \\
0\end{array}$ \\
\hline
\end{tabular}

GRANTS PASS.

Grants Pass is a dredged channel cut through the oyster beds which extend as a practically unbroken reef from Cedar Point to Little Dauphin Island and separate Mobile Bay from Mississippi Sound. The channel itself carries a minimum depth of about 11 feet, but at the Mobile Bay end the water shoals to about $8 \frac{1}{2}$ feet, and opposite the western or Mississippi Sound end to about $6 \frac{1}{2}$ feet at low water. There is a row of 7 dolphins or clusters of piles for 25 to 60 yards north of the thread of the channel. The oyster bed designated by the name of this pass is here arbitrarily assumed to lie not only in the deep water of the channel, but to extend as a strip about 200 to 250 yards wide on each side of the row of piles above described, with the exception of the cluster at the Mobile Bay end, which is assumed to lie in Big Gully bed. This bed was extensively worked by tongers during the period of the survey and with Pass aux Herons, which adjoins it to the south, produced the bulk of the oysters taken by tonging in the winter of 1910-11.

The extent and productiveness of this bed are shown on the table following. 
Oyster Growth in Grants Pass.

\begin{tabular}{|c|c|c|c|c|c|c|}
\hline \multirow{2}{*}{ Character of oyster growth. } & \multirow{2}{*}{ Area. } & \multicolumn{2}{|c|}{ Oysters per acre. } & \multicolumn{3}{|c|}{ Estimated content of oysters. } \\
\hline & & $\begin{array}{l}\text { Under } 3 \\
\text { inches. }\end{array}$ & $\begin{array}{l}\text { Over } 3 \\
\text { inches. }\end{array}$ & Seed. & Market. & Total. \\
\hline $\begin{array}{l}\text { Dense...... } \\
\text { Scattering. } \\
\text { Depleted.. }\end{array}$ & $\begin{array}{r}\text { Acres. } \\
64 \\
21 \\
42\end{array}$ & $\begin{array}{r}\text { Bushels. } \\
275 \\
159 \\
70\end{array}$ & $\begin{array}{r}\text { Bushels. } \\
359 \\
112 \\
22\end{array}$ & $\begin{array}{r}\text { Bushels. } \\
17,600 \\
3,339 \\
2,940\end{array}$ & $\begin{array}{r}\text { Bushels. } \\
22,976 \\
2,352 \\
924\end{array}$ & $\begin{array}{r}\text { Bushels. } \\
40,576 \\
5,691 \\
3,864\end{array}$ \\
\hline Total . & 127 & & 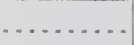 & 23,879 & 26,252 & 50,131 \\
\hline
\end{tabular}

About one-half of the area included within this bed is covered by a dense growth of market oysters, the eastern half being especially productive. The oysters are larger than most of those produced in this region and of better shape. There are many in the channel, especially south and east of Grants Island, but on account of the deep water, which reaches a maximum of 19 feet, and the strong currents the work is arduous at most times, and most of the tonging is done in depths of from 3 to 5 or 6 feet on the south side of the eastern half of the channel. No boats were observed at work on the north side of the row of dolphins.

The scattering growth on this bed lies in two patches - one of about 13 acres surrounding Grants Island and the other of about half the size between the easternmost two channel marks and continuous with the similar growth on Big Gully bed. The oysters in the latter area are somewhat larger and better than those surrounding Grants Island. The depleted bottom lies at the western end of the bed, between the dense growth and the barren bottom. Both the young and the market oysters here lie in patches of varying productiveness.

The following table shows the character of this bed at the several places at which detailed examinations were made:

Details of Examination of Grants Pass.

\begin{tabular}{|c|c|c|c|c|c|c|c|c|c|}
\hline \multirow{2}{*}{$\begin{array}{l}\text { Station } \\
\text { No. }\end{array}$} & \multirow{2}{*}{$\begin{array}{l}\text { Date of } \\
\text { examination. }\end{array}$} & \multirow{2}{*}{$\begin{array}{c}\text { Depth } \\
\text { of } \\
\text { water. }\end{array}$} & \multirow{2}{*}{ Character of growth } & \multicolumn{3}{|c|}{$\begin{array}{l}\text { Oysters caught per } \\
\text { square yard. }\end{array}$} & \multicolumn{3}{|c|}{$\begin{array}{l}\text { Estimated quantity of } \\
\text { oysters per acre. }\end{array}$} \\
\hline & & & & Spat. & Culls. & Counts. & Seed. & Market. & Total. \\
\hline $\begin{array}{l}180 \\
299 \\
425 \\
426 \\
427 \\
525 \\
526 \\
528 \\
529 \\
178 \\
179 \\
481 \\
527 \\
300 \\
301 \\
422 \\
423 \\
424\end{array}$ & 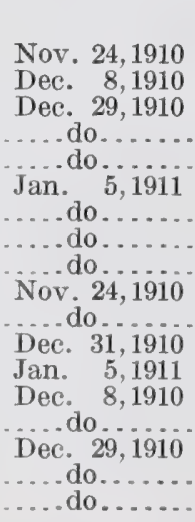 & $\begin{array}{r}\text { Feet. } \\
7.00 \\
4.30 \\
5.00 \\
4.50 \\
4.00 \\
17.00 \\
13.00 \\
14.00 \\
11.00 \\
6.25 \\
6.50 \\
2.00 \\
13.00 \\
4.50 \\
5.30 \\
5.50 \\
5.50 \\
3.00\end{array}$ & 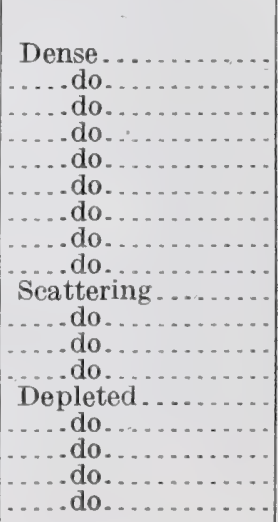 & $\begin{array}{r}6.7 \\
14.5 \\
7.5 \\
10.6 \\
.0 \\
10.8 \\
5.0 \\
10.0 \\
2.5 \\
5.2 \\
17.1 \\
17.4 \\
5.4 \\
13.3 \\
.0 \\
3.3 \\
2.0 \\
17.5\end{array}$ & $\begin{array}{r}31.1 \\
14.5 \\
23.8 \\
31.8 \\
46.5 \\
30.0 \\
25.0 \\
51.0 \\
32.5 \\
13.2 \\
5.5 \\
21.2 \\
5.9 \\
6.1 \\
.0 \\
.0 \\
3.3 \\
4.2\end{array}$ & $\begin{array}{r}25.6 \\
17.0 \\
17.5 \\
20.6 \\
16.5 \\
23.3 \\
45.0 \\
20.0 \\
16.6 \\
7.7 \\
7.1 \\
5.5 \\
7.7 \\
.0 \\
1.3 \\
.0 \\
5.3 \\
.4\end{array}$ & $\begin{array}{r}\text { Bush. } \\
265 \\
203 \\
219 \\
297 \\
326 \\
281 \\
210 \\
427 \\
245 \\
129 \\
158 \\
271 \\
79 \\
136 \\
0 \\
23 \\
37 \\
152\end{array}$ & $\begin{array}{r}\text { Bush. } \\
410 \\
272 \\
280 \\
330 \\
264 \\
373 \\
720 \\
320 \\
265 \\
123 \\
114 \\
88 \\
123 \\
0 \\
21 \\
0 \\
85 \\
6\end{array}$ & $\begin{array}{r}\text { Bush. } \\
675 \\
475 \\
499 \\
627 \\
590 \\
654 \\
930 \\
747 \\
510 \\
252 \\
272 \\
359 \\
202 \\
136 \\
21 \\
23 \\
122 \\
158\end{array}$ \\
\hline
\end{tabular}


PASS AUX HERONS.

This bed is continuous with the preceding and the following, without any definite demarcation of its boundaries. It surrounds a hole or blind pass from which it takes its name, in which there is a maximum depth of water of about 18 feet. The depth rapidly decreases, the water becoming quite shoal on each side and at the western end, although a draft of 5 or 6 feet can be carried on to the eastern end at low water.

This is in every respect the most important and prolific of the beds examined, and with the exception of Sand Reef, which has little or no present economic importance, it is, as arbitrarily defined here, the largest.

The following table summarizes the data relating to its extent, character of oyster growth, and content of oysters:

Oyster Growth in Pass aux Herons

\begin{tabular}{|c|c|c|c|c|c|c|}
\hline \multirow{2}{*}{ Character of oyster growth. } & \multirow{2}{*}{ Area. } & \multicolumn{2}{|c|}{ Oysters per acre. } & \multicolumn{3}{|c|}{ Estimated content of oysters. } \\
\hline & & $\begin{array}{l}\text { Under } 3 \\
\text { inches. }\end{array}$ & $\begin{array}{l}\text { Over } 3 \\
\text { inches. }\end{array}$ & Seed. & Market. & Total. \\
\hline $\begin{array}{l}\text { Dense } \\
\text { Scattering........ } \\
\text { Very scattering . } \\
\text { Depleted........ }\end{array}$ & $\begin{array}{r}\text { Acres. } \\
211 \\
14 \\
43 \\
24\end{array}$ & $\begin{array}{r}\text { Bushels. } \\
233 \\
32 \\
78 \\
15\end{array}$ & $\begin{array}{r}\text { Bushels. } \\
520 \\
94 \\
53 \\
4\end{array}$ & $\begin{array}{r}\text { Bushels. } \\
49,163 \\
448 \\
3,354 \\
360\end{array}$ & $\begin{array}{r}\text { Bushels. } \\
109,720 \\
1,316 \\
2,279 \\
96\end{array}$ & $\begin{array}{r}\text { Bushels. } \\
\mathbf{1 5 8 , 8 8 3} \\
1,764 \\
\mathbf{5 , 6 3 3} \\
\mathbf{4 5 6}\end{array}$ \\
\hline Total.. & 292 & & - & 53,325 & 113,411 & 166,736 \\
\hline
\end{tabular}

A dense growth having an average content of 520 bushels of market oysters per acre covers nearly 75 per cent of the entire area assumed for this bed, and in one place there are 1,170 bushels of market oysters and 1,494 bushels of all sizes per acre. The densest part of the bed lies between the deep water of the pass and Grants Pass, principally south and southeast of Grants Island. There is also a very dense area in a peninsula-like projection into Mobile Bay, about east of Grants Island and surrounded on the northeast and west by soft mud. During the winter of 1910-11 there were many tongers operating on these areas of very dense growth, and the best oysters produced in large quantities came from them. A larger proportion of oysters over 4 inches long was found here than at any other place examined in this vicinity. The areas of scattering growth occur in small patches of 9 and 4 acres, respectively, at the eastern or western limits of the bed. In the larger area the oysters are similar to those on the dense growth, with a considerable proportion of large ones of fair shape and quality.

There are three areas of very scattering growth, one at the eastern edge of the peninsula above referred to, another along the western 
edge of the dense area and the third separated from the precoding by a narrow belt of depleted bottom and continuous with the scattering arowth at the western limit of the bed, the two constituting practically a small detached bed.

Detalls of Examination of Pass aux Herons.

\begin{tabular}{|c|c|c|c|c|c|c|c|c|c|}
\hline \multirow{2}{*}{$\begin{array}{l}\text { Angle } \\
\text { No. }\end{array}$} & \multirow{2}{*}{$\begin{array}{c}\text { Date of } \\
\text { examination. }\end{array}$} & \multirow{2}{*}{$\begin{array}{l}\text { Depth } \\
\text { of } \\
\text { water. }\end{array}$} & \multirow{2}{*}{ Character of growth. } & \multicolumn{3}{|c|}{$\begin{array}{l}\text { Oysters caught per } \\
\text { square yard. }\end{array}$} & \multicolumn{3}{|c|}{$\begin{array}{l}\text { Estimated quantity oys- } \\
\text { ters per acre. }\end{array}$} \\
\hline & & & & Spat. & Culls. & Counts. & Seed. & Market. & Total. \\
\hline 165 & Nov. 23.1910 & $\begin{array}{c}\text { Feet. } \\
9.00\end{array}$ & & & & & Bush. & Bush. & Bush. \\
\hline $\begin{array}{l}106 \\
166\end{array}$ & .... do ...... & $\begin{array}{l}9.00 \\
8.00\end{array}$ & $\begin{array}{l}\text { Dense } \\
\text {.... do }\end{array}$ & $\begin{array}{l}0.0 \\
4.4\end{array}$ & $\begin{array}{l}1.0 \\
7.0\end{array}$ & $\begin{array}{r}6.0 \\
20.0\end{array}$ & só & $\begin{array}{r}96 \\
320\end{array}$ & 103 \\
\hline 167 & do.. & 7.00 & do & 11.1 & 10.0 & 20.7 & 148 & 333 & $\begin{array}{l}400 \\
481\end{array}$ \\
\hline 168 & do. & 7.00 & do. & 8.9 & 20.3 & 32.2 & 203 & 516 & 481 \\
\hline 169 & do. & 6.00 & do. & 8.1 & 22.5 & 30.0 & 214 & 480 & $\begin{array}{l}719 \\
694\end{array}$ \\
\hline 170 & do. & 10.00 & do. & 7.2 & 38.3 & 46.7 & 319 & 746 & $\begin{array}{r}694 \\
1065\end{array}$ \\
\hline 171 & do.. & 7.50 & do. & 5.2 & 33.2 & 36.4 & 269 & 583 & $\begin{array}{r}1009 \\
852\end{array}$ \\
\hline 176 & . do... & 5.25 & do.. & 14.0 & 22.9 & 10.5 & $25 s$ & 168 & 426 \\
\hline 177 & .. do ... & 4.50 & do. . & 41.8 & 61.3 & 15.3 & 722 & 245 & 967 \\
\hline 181 & Nov. 24,1910 & 7.00 & do & 11.8 & 24.1 & 39.6 & 251 & 634 & 885 \\
\hline 182 & .... do $\ldots . .$. . & 6.00 & do. & 4.2 & 32.3 & 38.4 & 256 & 615 & 871 \\
\hline 183 & ..... do.. & 6.50 & do. & 16.6 & 21.7 & 28.3 & $26 s$ & 453 & 721 \\
\hline 184 & . do. . & 6.00 & do & 11.9 & 40.0 & 52 & 364 & 837 & 1,201 \\
\hline 185 & do. & 5.50 & . do.. & 2.1 & 26.3 & 36.3 & 199 & 580 & 779 \\
\hline 186 & do. & 4.00 & do & 11.9 & 34.4 & 73.3 & 324 & 1.170 & 1,494 \\
\hline 187 & do. & 4.00 & do & 11.1 & 41.8 & 38.6 & 370 & 618 & 988 \\
\hline 188 & do. & 5.00 & do & 15.2 & 36.2 & 19.0 & 360 & 304 & 664 \\
\hline 189 & . do.. & 6.00 & do & 3.9 & 49.5 & 58 & 374 & 942 & 1.316 \\
\hline 190 & . do... & 7.50 & do & 8.0 & 50.8 & 56.7 & 412 & 908 & 1.320 \\
\hline 280 & Dec. \&, 1910 & 4.00 & do & 2.9 & 28.6 & 38 & 220 & 620 & 840 \\
\hline 281 & $\ldots$ do $\ldots$. . & 3.60 & do & .7 & 23.1 & 60.0 & 167 & 960 & 1,127 \\
\hline 282 & ..... do.. & 3.50 & do & 6.2 & 20.3 & 25 & $186^{\circ}$ & 414 & 600 \\
\hline 283 & ..... do . . & 3.60 & do & 2.8 & 34. & 23 & 263 & 381 & 644 \\
\hline 284 & do. & 4.00 & do & 8.9 & 18. & 58 & $1 \leqslant 9$ & 954 & 1,143 \\
\hline 285 & do & 4.8 & do & 2.4 & 39. & & 294 & 588 & 882 \\
\hline 286 & do. & 4.40 & do & .0 & 18. & 20 & 132 & 333 & 465 \\
\hline 287 & do. & 3.70 & do & 3.0 & 18. & 38 & 145 & 616 & 764 \\
\hline 288 & do & 4.0 & d & 1.5 & 18. & 50 & 140 & $\$ 12$ & 952 \\
\hline 289 & do & 3.3 & do & 1.9 & 19. & 13 & 149 & 216 & 365 \\
\hline 290 & do & 3.5 & . da & .7 & 26. & 31 & 193 & 506 & 699 \\
\hline 291 & do & 3.7 & do & 1.4 & 44. & 14 & 320 & 229 & 549 \\
\hline 292 & do & 4.5 & do & 2.5 & 42.5 & 64. & 315 & 1.030 & 1,345 \\
\hline 293 & do & 4. 20 & . d & .7 & 27.5 & 40 & 197 & 640 & 837 \\
\hline 294 & do & 2.6 & . d & 5. & 31. & 37 & 259 & 604 & 863 \\
\hline 295 & do & 2.8 & do & 8. & 28. & 54 . & 260 & 874 & 1,134 \\
\hline 296 & . de & 3.30 & 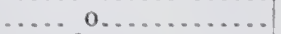 & .8 t & 6. & 4. & 47 & 67 & 114 \\
\hline 297 & de & 3.9 & $d$ & . & 12. & 20 & 92 & 328 & 420 \\
\hline 298 &.$d e$ & 3. & 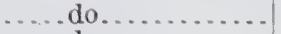 & $5 . \mathrm{C}$ & 18. & 21. & 161 & 336 & 497 \\
\hline 305 & . do & 4.0 & d & .5 & 24 & & 175 & 584 & 759 \\
\hline 309 & do & 3. & d & 7.1 & 17. & 12. & 172 & 206 & 378 \\
\hline 331 & Dec. 9,1910 & 2.30 & 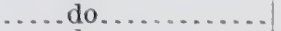 & 6.4 & 15. & 28 & 151 & 454 & 605 \\
\hline 332 & .... do....... & 2.80 & $d$ & 21.7 & 56.2 & 29.6 & 545 & 473 & 1.018 \\
\hline$a 342$ & $\ldots$. do $\ldots$... & & & & & & & & \\
\hline 520 & Jan. 2.1911 & 18.00 & $d$ & .0 & 14. & 22. & 103 & 363 & 466 \\
\hline 522 & Jan. $\bar{j}, 1911$ & 18.00 & $d$ & 9.2 & 16. & 3. & 180 & 48 & 228 \\
\hline 524 & .... do do.... & 17.00 & 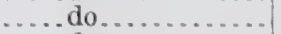 & 5.8 & 41. & 34 & 332 & 544 & 876 \\
\hline 173 & Nov. 23,1910 & 10.00 & . d & 4.5 & 15. & 31.2 & 141 & 500 & 641 \\
\hline 174 & $\ldots$ do $\ldots . .$. & 10. & $\cdots$ & .0 & 3. & 12.2 & 23 & 195 & 218 \\
\hline & .... do do & 10. & Seatt & 1.7 & 0. & 4. & It & 72 & 88 \\
\hline & & 7. & Ne & .0 & 1. & 3. & il & 48 & 58 \\
\hline & Nov, 2 & & & 2.1 & 3.1 & 8. & 36 & 142 & 178 \\
\hline 310 & Dec. 8,1910 & 5.8 & 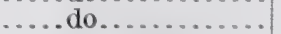 & .7 & 8.5 & 7.1 & $6 t$ & 114 & 178 \\
\hline 192 & Nov. 24,1910 & 7.5 & Ver & 1.6 & 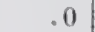 & 2.4 & 11 & 38 & 49 \\
\hline 304 & Dec. 8,1910 & 3.80 & $\ldots . . . d$ & 6.5 & 4.8 & 6. & 70 & 104 & 174 \\
\hline 306 & .... do ....... & 4.30 & ......d & 2.0 & 1.5 & 2. & 25 & 40 & 65 \\
\hline & .... do & 3.8 & & 1.5 & 3. & 2.5 & 32 & 40 & 72 \\
\hline & .. do & 3.40 & . & 10.9 & 6.4 & 2.7 & 121 & 43 & 164 \\
\hline & $\ldots$. do $\ldots \ldots$. & 3. & . & 26.4 & 10.0 & 3.6 & 255 & 58 & 313 \\
\hline & Dec. 7.1910 & 5.50 & $\ldots . .$. & 4.7 & .0 & 3.2 & 33 & 51 & 84 \\
\hline 302 & Dec. 8.1910 & 4.60 & Depleted.. & 2.2 & .0 & $\begin{aligned} 0.2 \\
.0\end{aligned}$ & $\begin{array}{l}03 \\
15\end{array}$ & 0 & 15 \\
\hline 303 & $\ldots \ldots$ do $\ldots . .$. & 4. 20 & & 2.0 & 2.5 & 1.0 & 32. & 16 & 48 \\
\hline & $\ldots d$ & 4.90 & $\ldots$.... d & .0 & .0 & 0 & 0 & 0 & 0 \\
\hline 3 & .d & 3.5 & 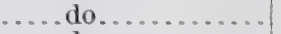 & 4.5 & 1.8 & .5 & 44 & 8 & 52 \\
\hline 314 & . d & 4.8 & & .0 & .0 & 0 & 0 & 0 & 0 \\
\hline 315 &. $\mathrm{~d}$ & 5.20 & d & .0 & .0 & .0 & () & 0 & 0 \\
\hline
\end{tabular}

a Exposed reef; living oysters large and small. 


\section{REDFISH GULI, I.}

Redfish gully is a strip of slightly deeper water lying between the shoals south of Pass aux Heroms and the bar, bare at extreme low tide in winter, extending for about 800 yards northwest from the tip of I ittle Dauphin Island. The shallowest part of this gully has a depth of about 3 feet at low water, the averace is about 6 inches deeper and near the western end is a hole in which there is a maximum of 7 fect or more. The oyster bed designated by this name lics in and about the gully.

The following table shows the extent, character of oyster growth, and estimated content of this bed:

Oyster Growth in Redfish Gully.

\begin{tabular}{|c|c|c|c|c|c|c|}
\hline \multirow{2}{*}{ Character of oyster growth. } & \multirow{2}{*}{ Area. } & \multicolumn{2}{|c|}{ Oysters per acre. } & \multicolumn{3}{|c|}{ Estimated content of oysters. } \\
\hline & & $\begin{array}{l}\text { Under } 3 \\
\text { inches. }\end{array}$ & $\begin{array}{l}\text { Over } 3 \\
\text { inches. }\end{array}$ & Seed. & Market. & Total. \\
\hline $\begin{array}{l}\text { Dense........ } \\
\text { Scattering... }\end{array}$ & $\begin{array}{r}\text { Acres. } \\
209 \\
11\end{array}$ & $\begin{array}{r}\text { Bushels. } \\
231 \\
26\end{array}$ & $\begin{array}{r}\text { Bushels. } \\
313 \\
80\end{array}$ & $\begin{array}{r}\text { Bushels. } \\
48,279 \\
286\end{array}$ & $\begin{array}{r}\text { Bushels, } \\
65,417 \\
880\end{array}$ & $\begin{array}{r}\text { Bushels. } \\
113,696 \\
1,166\end{array}$ \\
\hline Total ....... & 220 & n......... & ........... & 48,565 & 66,297 & 114,862 \\
\hline
\end{tabular}

Practically all of this bed consists of dense growth, there being but one patch of about 11 acres of scattering oysters near the northeast edge, where there is a considerable proportion of large oysters of good shape.

On the dense growth market oysters are least abundant in and about the deeper water in the southwestern part of the bed. The proportion of oysters over 4 inches in length is greatest in the eastern part of the bed, adjoining Mobile Bay, and it was there that most of the boats were observed working on the bed, although there were three or four schooners operating in the deep hole.

Details of Examination of Redfish Gully.

\begin{tabular}{|c|c|c|c|c|c|c|c|c|c|}
\hline \multirow{2}{*}{$\begin{array}{l}\text { Angle } \\
\text { No. }\end{array}$} & \multirow{2}{*}{$\begin{array}{l}\text { Date of } \\
\text { examination. }\end{array}$} & \multirow{2}{*}{$\begin{array}{c}\text { Depth } \\
\text { of } \\
\text { water. }\end{array}$} & \multirow{2}{*}{ Character of growtb. } & \multicolumn{3}{|c|}{$\begin{array}{l}\text { Oysters caught per } \\
\text { square yard. }\end{array}$} & \multicolumn{3}{|c|}{$\begin{array}{c}\text { Estimated quantity oys- } \\
\text { ters per acre. }\end{array}$} \\
\hline & & & & Spat. & Culls. & Counts. & Seed. & Market. & Total. \\
\hline & & Feet. & & & & & Bush. & Bush. & Bush. \\
\hline 156 & Nov. 23,1910 & 7.00 & Dense. & 5.3 & 20.0 & 30.7 & 177 & 492 & 669 \\
\hline 157 & ..... do......... & 5.00 & do. & 13.8 & 31.4 & 38.1 & 317 & 610 & 927 \\
\hline 158 & .... do.. & 4.50 & do. & 8.1 & 10.7 & 27.0 & 132 & 432 & 564 \\
\hline 159 & do... & 6.00 & do. & 12.8 & 26.6 & 24.4 & 276 & 391 & 667 \\
\hline 160 & do.. & 6.00 & do. & 11.1 & 18.3 & 13.3 & 206 & 213 & 419 \\
\hline 161 & do.. & 8.00 & do. & 7.3 & 7.3 & 14.7 & 102 & 235 & 337 \\
\hline 193 & Nov. 24,1910 & 7.00 & do. & 13.3 & 14.5 & 10.7 & 195 & 171 & 366 \\
\hline 211 & ... do......... & 3.40 & do. & .0 & 21.0 & 21.9 & 147 & 350 & 497 \\
\hline 321 & Dec. 8,1910 & $\begin{array}{l}3.90 \\
3.90\end{array}$ & do & 11.5 & 11.5 & 11.0 & 161 & 176 & 337 \\
\hline 322 & $\ldots$............. & 4.00 & $a$ & 4. 0 & 19.5 & 10.5 & 165 & 168 & 333 \\
\hline 323 & ... do...... & 4. 40 & do. & 4.4 & 30.0 & 20.0 & 241 & 320 & -561 \\
\hline 324 & do..... & 4. 40 & do.. & 2.2 & 28.8 & 10.0 & 217 & 160 & 377 \\
\hline 333 & Dec. 9,1910 & 2.00 & do. & 5.8 & 42.0 & 23.6 & 335 & 378 & 713 \\
\hline 339 & ..... do........... & 6.20 & do. & 12.3 & 26.2 & 26.9 & 270 & 430 & 700 \\
\hline 340 & $\ldots$ do & 2.90 & do. & 13.1 & 51.3 & 28.8 & 451 & 461 & 912 \\
\hline 341 & do.. & 2.90 & & 9.6 & 22.9 & 5.4 & 228 & 864 & 1,092 \\
\hline 343 & do... & 2.90 & do. & 2.1 & 41.7 & 26.3 & 307 & 470 & 777 \\
\hline 162 & Nov. 23,1910 & 8.00 & Seattering. & 2.0 & 5.3 & 3.3 & 51 & 53 & 104 \\
\hline 163 & ..... do..... & 6.00 & ... do... & .0 & .0 & 6.7 & 0 & 107 & 107 \\
\hline
\end{tabular}




\section{BLACK LUMPS.}

This bed lies west of Redfish Gully and south of the western part of Pass aux IIerons and is continuous with both. The name as used by the oystermen appears to be of very indefinite application and is probably more restricted than as employed in this report. Some of the oysters in the part immediately adjoining Pass aux Herons are excellent, but in most places they are inferior. Drills were found in abundance at places on this bed and a great many small spat had been killed by them.

The area, conditions of oyster growth, and total contents of seed and marketable oysters are shown in the following table:

Oyster Growth on Black Lumps.

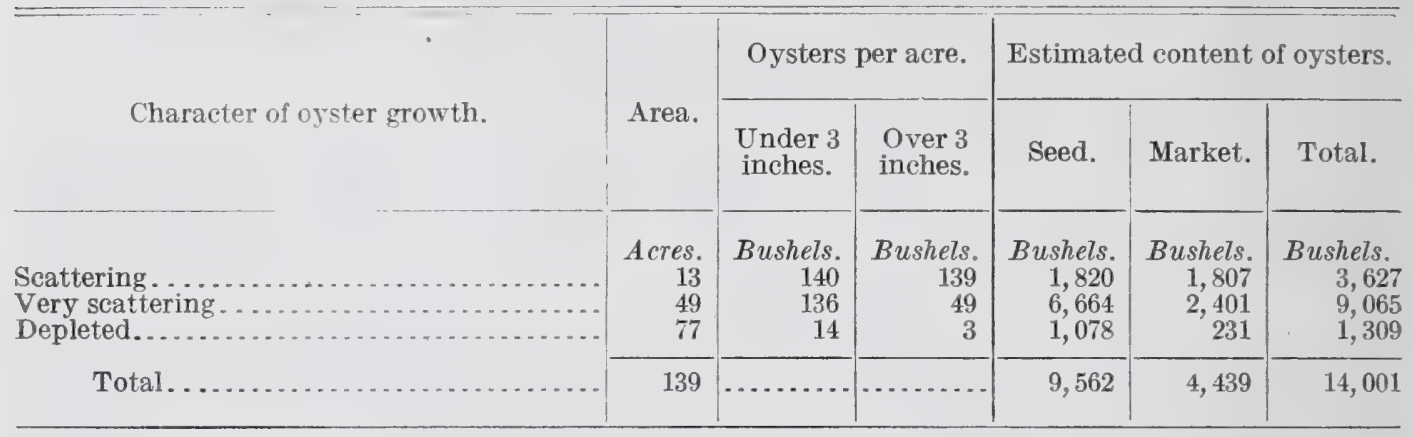

The scattering growth occurs as a small area adjoining the southwest corner of Redfish Gully bed, and south of it is a small patch of very scattering growth. A larger area of the latter is found at the northeast corner of the bed, in the angle between Pass aux Herons and Redfish Gully beds. The depleted bottom, which comprises the major part of the bed, lies in the western and southern part.

The detailed data of the examination are as follows:

Details of Examination of Black Lumps.

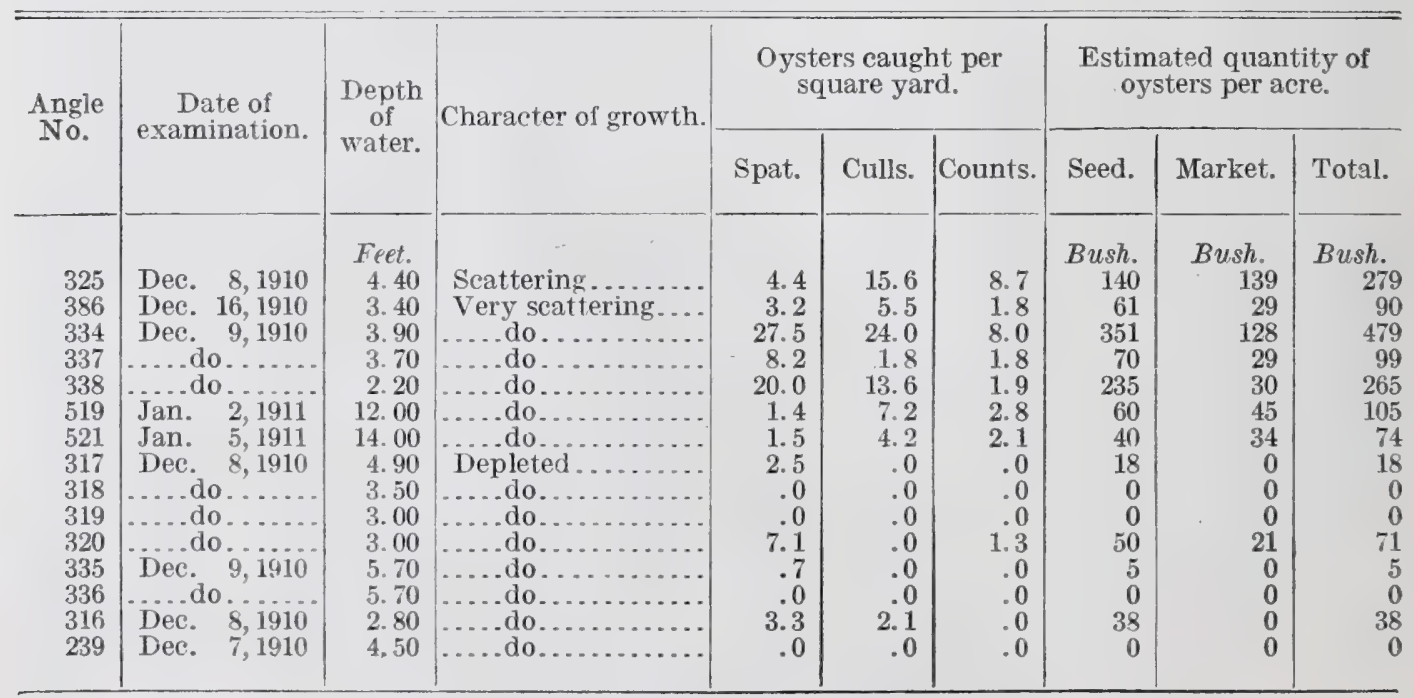




\section{WEST SIDE OF LITTLE DAUPHIN ISLAND.}

This is an economically unimportant bed lying between the Turtle Hole, Mussel Gully, and Redfish Gully. A large part of it lies on bottom which is exposed during low winter tides. The extent and density of oyster growth are as follows:

Oyster Growth on West Side of Little Dauphin Island.

\begin{tabular}{|c|c|c|c|c|c|c|}
\hline \multirow{2}{*}{ Character of oyster growth. } & \multirow{2}{*}{ Area. } & \multicolumn{2}{|c|}{ Oysters per acre. } & \multicolumn{3}{|c|}{ Estimated content of oysters. } \\
\hline & & $\begin{array}{l}\text { Under } 3 \\
\text { inches. }\end{array}$ & $\begin{array}{l}\text { Over } 3 \\
\text { inches. }\end{array}$ & Seed. & Market. & Total. \\
\hline $\begin{array}{l}\text { Very scattering. } \\
\text { Depleted....... }\end{array}$ & $\begin{array}{r}\text { Acres. } \\
9 \\
156\end{array}$ & $\begin{array}{r}\text { Bushels. } \\
58 \\
9\end{array}$ & $\begin{array}{r}\text { Bushels. } \\
35 \\
4\end{array}$ & $\begin{array}{r}\text { Bushels. } \\
522 \\
1,404\end{array}$ & $\begin{array}{r}\text { Bushels. } \\
315 \\
624\end{array}$ & $\begin{array}{r}\text { Bushels. } \\
837 \\
2,028\end{array}$ \\
\hline Total. . & 165 & . . . & & 1,926 & 939 & 2,865 \\
\hline
\end{tabular}

There is an insignificant patch of very scattering growth adjoining a small shell island northeast of Turtle Hole, and the rest of the bed is depleted. The proportion of dead oysters is very large in all parts of the bed, and drills, which appear to be the principal cause of the mortality, are abundant. The following examinations were made:

Details of Examination of West Side of Little Dauphin Island.

\begin{tabular}{|c|c|c|c|c|c|c|c|c|c|}
\hline \multirow{2}{*}{$\begin{array}{l}\text { Angle } \\
\text { No. }\end{array}$} & \multirow{2}{*}{$\begin{array}{c}\text { Date of } \\
\text { examination. }\end{array}$} & \multirow{2}{*}{$\begin{array}{l}\text { Depth } \\
\text { of } \\
\text { water. }\end{array}$} & \multirow{2}{*}{ Character of growth. } & \multicolumn{3}{|c|}{$\begin{array}{l}\text { Oysters caught per } \\
\text { square yard. }\end{array}$} & \multicolumn{3}{|c|}{$\begin{array}{c}\text { Estimated quantity oys- } \\
\text { ters per acre. }\end{array}$} \\
\hline & & & & Spat. & Culls. & Counts. & Seed. & Market. & Total. \\
\hline $\begin{array}{l}392 \\
326 \\
327 \\
328 \\
329 \\
330 \\
385 \\
387 \\
388 \\
389\end{array}$ & 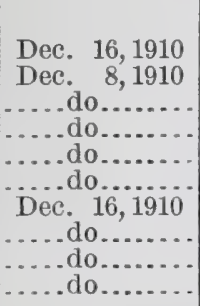 & $\begin{array}{c}\text { Feet. } \\
1.00 \\
3.80 \\
2.60 \\
2.60 \\
3.10 \\
4.20 \\
3.20 \\
2.30 \\
2.20 \\
1.40\end{array}$ & 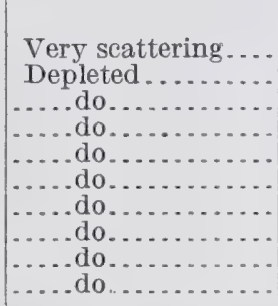 & $\begin{array}{l}0.8 \\
.0 \\
4.1 \\
3.7 \\
.0 \\
.0 \\
.0 \\
.0 \\
.3 \\
.0\end{array}$ & $\begin{array}{r}7.5 \\
.0 \\
.0 \\
.0 \\
.0 \\
.0 \\
.0 \\
.0 \\
.7 \\
2.1\end{array}$ & $\begin{array}{r}2.2 \\
.0 \\
.7 \\
.0 \\
.0 \\
.0 \\
.0 \\
.0 \\
1.3 \\
.3\end{array}$ & $\begin{array}{r}\text { Bush. } \\
58 \\
0 \\
29 \\
26 \\
0 \\
0 \\
0 \\
0 \\
7 \\
15\end{array}$ & $\begin{array}{r}\text { Bush. } \\
35 \\
0 \\
11 \\
0 \\
0 \\
0 \\
0 \\
0 \\
21 \\
5\end{array}$ & $\begin{array}{r}\text { Bush. } \\
93 \\
0 \\
40 \\
26 \\
0 \\
0 \\
0 \\
0 \\
28 \\
20\end{array}$ \\
\hline
\end{tabular}

\section{MUSSEL GULLY.}

Mussel Gully lies northwest of Little Dauphin Island, running northeast from Turtle Hole and ending blindly in a sand flat. The beds which bear its name, as considered in this report, lie between the gully and the island. They are of no importance and are badly infested with drills.

The following tables furnish all necessary information:

Oyster Growth in Mussel Gully.

\begin{tabular}{|c|c|c|c|c|c|c|}
\hline \multirow{2}{*}{ Character of oyster growth. } & \multirow{2}{*}{ Area. } & \multicolumn{2}{|c|}{ Oysters per acre. } & \multicolumn{3}{|c|}{ Estimated content of oysters. } \\
\hline & & $\begin{array}{l}\text { Under } 3 \\
\text { inches. }\end{array}$ & $\begin{array}{l}\text { Over } 3 \\
\text { inches. }\end{array}$ & Seed. & Market. & Total. \\
\hline $\begin{array}{l}\text { Very scattering.. } \\
\text { Depleted......... }\end{array}$ & $\begin{array}{r}\text { Acres. } \\
11 \\
32\end{array}$ & $\begin{array}{r}\text { Bushels. } \\
123 \\
51\end{array}$ & $\begin{array}{r}\text { Bushels. } \\
27 \\
0\end{array}$ & $\begin{array}{r}\text { Bushels. } \\
1,353 \\
1,632\end{array}$ & $\begin{array}{r}\text { Bushels. } \\
297 \\
0\end{array}$ & $\begin{array}{r}\text { Bushels. } \\
1,650 \\
1,632\end{array}$ \\
\hline Total...... & 43 & .... & .......... & 2,985 & 297 & 3,282 \\
\hline
\end{tabular}


Detalls of Examination of Mussel Gully.

\begin{tabular}{|c|c|c|c|c|c|c|c|c|c|}
\hline \multirow{2}{*}{$\begin{array}{l}\text { Ingle } \\
\text { No. }\end{array}$} & \multirow{2}{*}{$\begin{array}{l}\text { Date of } \\
\text { examination. }\end{array}$} & \multirow{2}{*}{$\begin{array}{l}\text { Depth } \\
\text { of } \\
\text { water. }\end{array}$} & \multirow{2}{*}{ Charicter of growth. } & \multicolumn{3}{|c|}{$\begin{array}{l}\text { Oysters caught per } \\
\text { square yard. }\end{array}$} & \multicolumn{3}{|c|}{$\begin{array}{c}\text { Estimated quantity ors- } \\
\text { ters per acre. }\end{array}$} \\
\hline & & & & Spat. & Culls. & Counts. & Seed. & Market. & Total. \\
\hline $\begin{array}{l}393 \\
395\end{array}$ & $\begin{array}{l}\text { Dec. } 16,1910 \\
\ldots \text { do............. }\end{array}$ & $\begin{array}{l}\text { Feet. } \\
1.00 \\
1.00\end{array}$ & $\begin{array}{l}\text { Very scattering.... } \\
\text { Depleted.......... }\end{array}$ & $\begin{array}{r}6.1 \\
.0\end{array}$ & $\begin{array}{r}11.4 \\
7.3\end{array}$ & $\begin{array}{r}1.7 \\
.0\end{array}$ & $\begin{array}{r}\text { Bush. } \\
123 \\
51\end{array}$ & $\begin{array}{r}\text { Bush. } \\
27 \\
0\end{array}$ & $\begin{array}{r}\text { Bush. } \\
150 \\
51\end{array}$ \\
\hline
\end{tabular}

SATD REEF.

This bed lies in Mobile Bay, stretching from Ralfish Gully to Pass Drury for a distance of about $2 \frac{1}{2}$ miles along the outsicle of Little Damphin Island. It has an arerage wilth of about one-third mile from above low-water mark to a depth of about 10 feet. It is the largest bed falling within the limits of this report, but at the time of examination it was of comparatively little economic ralue, and at no time were boats observed at work on it. Its extent, the distribution of orster growth, and content of orsters are shown in the following table:

Oyster Growth on Sand Reef.

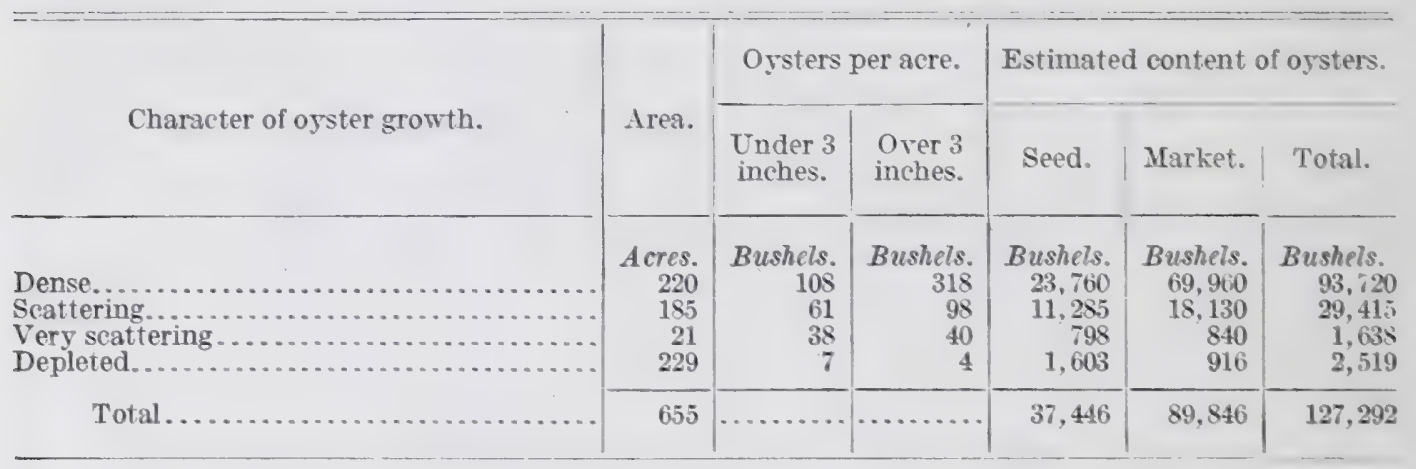

The dense growth covers a nearly continuous strip rumning the entire length of the bed. The oysters occur in rather large clusters and are of medium size, with comparatively few orer $t$ inches long. and inferior in shape and quality. The scattering growth lies principally inshore of the upper or northeast half of the dense area, extending well up to or above low-water mark. The oysters lie in clusters and are apparently tossed about by the wares and often more or less submerged in the sand. The very scattering growth fringes the offshore edge of the upper third of the dense area. The depleted bottom, which is the most extensive of the four classes of orster growth represented, lies mainly in a large body in the half of the bed close to the mouth of the bay. The orsters on this bed probably rarely, if ever, become fit for market, and are of value as seed only, and even for such purposes they should be used with caution, owing to the danger of transplanting the drills which abound. 
The following examinations were made:

Details of Examination of Sand Reef.

\begin{tabular}{|c|c|c|c|c|c|c|c|c|c|}
\hline \multirow{2}{*}{$\begin{array}{l}\text { Angle } \\
\text { No. }\end{array}$} & \multirow{2}{*}{$\begin{array}{l}\text { Date of } \\
\text { examination. }\end{array}$} & \multirow{2}{*}{$\begin{array}{l}\text { Depth } \\
\text { of } \\
\text { water. }\end{array}$} & \multirow{2}{*}{ Character of growth. } & \multicolumn{3}{|c|}{$\begin{array}{l}\text { Oysters caught per } \\
\text { square yard. }\end{array}$} & \multicolumn{3}{|c|}{$\begin{array}{c}\text { Estimated quantity oys- } \\
\text { ters per acre. }\end{array}$} \\
\hline & & & & Spat. & Culls. & Counts. & Seed. & Market. & Total. \\
\hline & & $\begin{array}{l}\text { Feet. } \\
\text { 4.00 }\end{array}$ & & & & & Bush. & Bush. & Bush. \\
\hline 123 & Nov 23,1910 & $\begin{array}{l}4.00 \\
4.50\end{array}$ & Dense... & $\begin{array}{r}5.9 \\
.0\end{array}$ & $\begin{array}{l}3.3 \\
3.7\end{array}$ & $\begin{array}{l}11.1 \\
17.8\end{array}$ & $\begin{array}{l}64 \\
21\end{array}$ & $\begin{array}{l}178 \\
285\end{array}$ & $\begin{array}{l}242 \\
306\end{array}$ \\
\hline 131 & .....do... & 5.00 & ......do. & 2.4 & 8.1 & 12.4 & 74 & 198 & $\begin{array}{l}306 \\
273\end{array}-10$ \\
\hline $\begin{array}{l}132 \\
133\end{array}$ & do. & $\begin{array}{l}5.00 \\
4.50\end{array}-$ & do & 3.8 & $\begin{array}{l}5.7 \\
5.5\end{array}$ & $\begin{array}{l}14.3 \\
13.3\end{array}$ & 66 & 229 & 295 \\
\hline 135 & ...do.. & 4.50 & ..do. & .0 & 12.6 & $\begin{array}{l}11.9 \\
11.9\end{array}$ & $\begin{array}{l}54 \\
88\end{array}$ & ${ }_{190}^{213}$ & 267 \\
\hline 136 & …..do.. & 4.00 & do. & 11.1 & 8.9 & 30.0 & 140 & 480 & 620 \\
\hline 137 & ......do.. & 4. 00 & .. do. & 1.5 & 5. 2 & 25.2 & 47 & 404 & 451 \\
\hline 139 & .....do.. & 5.00 & ..do. & 8.6 & 21.0 & 33.8 & 207 & 540 & 747 \\
\hline 142 & ......do... & 5. 00 & . do. & 4.3 & 11.4 & 24.3 & 110 & 389 & 499 \\
\hline 143 & & 5.75 & do. & 2.8 & 5.0 & 14.4 & 55 & 230 & 285 \\
\hline 196 & Nov; 24,1910 & $\begin{array}{l}3.00 \\
3.00\end{array}$ & do. & $\begin{array}{l}4.5 \\
1.6\end{array}$ & $\begin{array}{l}8.4 \\
4.2\end{array}-1$ & $\begin{array}{l}10.0 \\
14.9\end{array}$ & $\begin{array}{l}90 \\
41\end{array}$ & 160 & 250 \\
\hline 198 & n.....do. & 2.90 & do & (a) & 13. 6 & $\begin{array}{l}14.9 \\
16.2\end{array}$ & $(a)^{41}$ & $\begin{array}{l}238 \\
259\end{array}$ & 279 \\
\hline 201 & . do... & 4.25 & do. & 16.0 & 8.1 & 13.3 & 169 & 213 & 333 \\
\hline 148 & Nov. 23,1910 & 400 & .do. & 2.6 & 9.6 & 13.7 & 85 & 219 & $\begin{array}{ll}304 \\
304\end{array}$ \\
\hline 149 & .....do.... & & do & 7.9 & 19.5 & 25.8 & 192 & 413 & 605 \\
\hline 150 & .....do. & 7. 00 & do. & 10.0 & 14.7 & 25.3 & 173 & 405 & 578 \\
\hline 152 & ......do... & 7.00 & do. & 2.0 & 16.7 & & 131 & 576 & 707 \\
\hline & ......do. . & 5.00 & do & 8.6 & 18.1 & & 187 & 472 & 659 \\
\hline 154 & 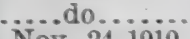 & $\begin{array}{l}5.00 \\
7\end{array}$ & do & 4.3 & 27.2 & & 220 & 535 & 755 \\
\hline 194 & Nov, 24,1910 & & . do & 4.8 & 9.6 & & 101 & 171 & 272 \\
\hline 207 & ….ddo........ & $\begin{array}{l}3.40 \\
4.00\end{array}$ & $\begin{array}{l}\text {.do } \\
\text {.do }\end{array}$ & $\begin{array}{l}1.3 \\
1.5\end{array}$ & $\begin{array}{l}7.1 \\
9.2\end{array}$ & $\begin{array}{ll}10.3 \\
10.4\end{array}$ & 59 & 165 & 224 \\
\hline 209 & ..d & & do & 1.1 & 19.7 & 10.7 & 146 & 614 & $\begin{array}{l}242 \\
760\end{array}$ \\
\hline-195 & .....do. & 3.00 & Scatteru & 3.5 & 4.2 & 6.8 & 54 & 109 & $\begin{array}{l}760 \\
163\end{array}$ \\
\hline 140 & Nor. 23,1910 & 4.50 & do & 15.6 & 5.6 & & 143 & 142 & $\begin{array}{l}103 \\
290\end{array}$ \\
\hline 144 & ....do.... & & do & 1.7 & 23.9 & & 179 & 80 & 259 \\
\hline 199 & Nov, 24,1910 & & & .6 & 1.3 & 1.3 & 13 & 21 & 34 \\
\hline 200 & ......do........ & & $\ldots . .$. de & .0 & 4.2 & 6.1 & 29 & 98 & 127 \\
\hline 202 & .....do.......... & 3.50 & ….do & 3.2 & 9.0 & 7.1 & 92 & 114 & 206 \\
\hline 206 & ..... do... & $\begin{array}{r}2.50 \\
2.50\end{array}$ & ....do. & .00 & .33 & $\begin{array}{l}6.8 \\
9.0\end{array}$ & $\frac{2}{17}$ & $\begin{array}{l}109 \\
144\end{array}$ & 111 \\
\hline 210 & do........ & & & .0 & 2.6 & & 18 & 67 & $\begin{array}{r}161 \\
85\end{array}$ \\
\hline 147 & Nor. 23,1910 & 6. 00 & Verr seattering & .6 & 1.1 & 1.7 & 2 & 27 & $\begin{array}{l}85 \\
39\end{array}$ \\
\hline 151 & . do... & & ....do & .0 & 1.3 & .0 & 72 & 0 & $\begin{array}{l}39 \\
72\end{array}$ \\
\hline 155 &. & & .... d & .0 & .0 & 4.4 & 0 & 72 & $\begin{array}{l}78 \\
72\end{array}$ \\
\hline 204 & Nov. 24,1910 & & & 3.2 & 6.5 & 3.9 & 68 & 62 & 130 \\
\hline 115 & Nov. 23,1910 & & Deple & .0 & .0 & .0 & 0 & 0 & 0 \\
\hline${ }_{117}^{116}$ & .....do. & & d & .0 & & .0 & & 0 & 0 \\
\hline 118 & $d$ & & $\ldots d d$ & 1. 3 & .00 & .0 & $\begin{array}{l}0 \\
9\end{array}$ & $\begin{array}{l}0 \\
0\end{array}$ & 0 \\
\hline 119 & d & & .0 & 1.3 & .0 & .0 & 9 & & $\stackrel{9}{9}$ \\
\hline &. d & & $\ldots d$ & .0 & .0 & .0 & 0 & & 9 \\
\hline & d & 5.00 & ..d & .0 & .0 & .0 & 0 & 0 & 0 \\
\hline & ..d & 6.00 & ...d & .0 & .0 & .0 & 0 & 0 & $\begin{array}{l}0 \\
0\end{array}$ \\
\hline & & & & .5 & 1.0 & .5 & 10 & 8 & $\begin{array}{l}0 \\
18\end{array}$ \\
\hline & $d$ & 9. 50 & $\ldots d$ & 0 & .0 & .0 & 0 & 0 & 0 \\
\hline & $d$ & & d & .5 & .0 & .0 & 3 & 0 & 3 \\
\hline 12 & .d & & $d$ & $\cdot 4$ & .4 & $2_{4}^{7}$ & 6 & $\begin{array}{l}11 \\
32\end{array}$ & 17 \\
\hline 130 & .0 & & $\ldots d$ & .0 & 0 & 2.4 & 0 & $\begin{array}{r}88 \\
0\end{array}$ & 38 \\
\hline & d & 5. & .d & .0 & 0 & .0 & 0 & 0 & $\begin{array}{l}\theta \\
\theta\end{array}$ \\
\hline & & & d & 0 & 1.7 & .0 & 12 & 0 & 12 \\
\hline 14 & & & & 8 & $\therefore 8$ & 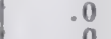 & 4 & 0 & 4 \\
\hline $\begin{array}{l}146 \\
203\end{array}$ & Nov. 24,1910 & $\begin{array}{l}7.00 \\
2.50\end{array}$ & ..d & $\begin{array}{l}\text { 2.0 } \\
\text { 3. }\end{array}$ & $\begin{array}{l}\text { 3.3 } \\
\text { 3. }\end{array}$ & $\begin{array}{r}.0 \\
1.0\end{array}$ & 45 & $\begin{array}{r}0 \\
16\end{array}$ & $\begin{array}{l}37 \\
61\end{array}$ \\
\hline & & & & & & & & & \\
\hline
\end{tabular}

a Many.

\section{DAUPHIN ISLAND BAY.}

Practically the entire bottom of this bay is sparsely covered with oyster growth, but in only a few patches in the southeastern half is the growth sufficiently productive to warrant tonging.

The area and character of oyster growth and the estimated content of oysters in the bay are shown in the table following. 
Oyster Growth in Dauphin Island Bay.

\begin{tabular}{|c|c|c|c|c|c|c|}
\hline \multirow{2}{*}{ Character of oyster growth. } & \multirow{2}{*}{ Area. } & \multicolumn{2}{|c|}{ Oysters per acre. } & \multicolumn{3}{|c|}{ Estimated content of oysters. } \\
\hline & & $\begin{array}{l}\text { Under } 3 \\
\text { inches. }\end{array}$ & $\begin{array}{l}\text { Over } 3 \\
\text { inches. }\end{array}$ & Seed. & Market. & Total. \\
\hline 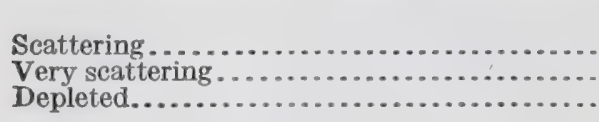 & $\begin{array}{r}\text { Acres. } \\
52 \\
154 \\
550\end{array}$ & $\begin{array}{r}\text { Bushels. } \\
49 \\
25 \\
48\end{array}$ & $\begin{array}{r}\text { Bushels. } \\
104 \\
45 \\
3\end{array}$ & $\begin{array}{r}\text { Bushels. } \\
2,548 \\
3,850 \\
26,400\end{array}$ & $\begin{array}{r}\text { Bushels. } \\
5,408 \\
6,930 \\
1,650\end{array}$ & $\begin{array}{r}\text { Bushels. } \\
7,956 \\
10,780 \\
28,050\end{array}$ \\
\hline Total.. & 756 & & & 32,798 & 13,988 & 46,786 \\
\hline
\end{tabular}

There are three areas of what this report designates as scattering oysters, one of about 6 acres close to the Dauphin Island shore, and two larger ones near Little Dauphin Island. It is stated that oysters are planted or bedded in the bay, and it is possible that some of the bottom included in the foregoing is not wholly natural bed.

Included between these three patches is a considerable area of very scattering growth. The depleted bottom lies around the shores south and west of the preceding and in the entire northwestern part of the bay where there are practically no market oysters and but a limited quantity of small ones.

The oysters in practically all parts of the bay were poor in shape and quality. Some drills were found and many dead small oysters.

Details of Examination of Dauphin Island Bay.

\begin{tabular}{|c|c|c|c|c|c|c|c|c|c|}
\hline \multirow{2}{*}{$\begin{array}{l}\text { Angle } \\
\text { No: }\end{array}$} & \multirow{2}{*}{$\begin{array}{c}\text { Date of } \\
\text { examination. }\end{array}$} & \multirow{2}{*}{$\begin{array}{c}\text { Depth } \\
\text { of } \\
\text { water. }\end{array}$} & \multirow{2}{*}{ Character of growth. } & \multicolumn{3}{|c|}{$\begin{array}{l}\text { Oysters caught per } \\
\text { square yard. }\end{array}$} & \multicolumn{3}{|c|}{$\begin{array}{c}\text { Estimated quantity oys- } \\
\text { ters per acre. }\end{array}$} \\
\hline & & & & Spat. & Culls. & Counts. & Seed. & Market. & Total. \\
\hline & & Feet. & & & & & Bush. & Bush. & Bush. \\
\hline 222 & Dec. 5,1910 & 1.50 & Scattering. & 0.0 & 3.6 & 7.7 & & 123 & 148 \\
\hline 225 & .....do.......... & 1.80 & ......do..... & .0 & 3.0 & 8.6 & 21 & 138 & 159 \\
\hline 213 & ......do.......... & 2.00 & .....do. & .0 & 3.0 & 6.3 & 21 & 101 & 122 \\
\hline 229 & .....do.... & 6.00 & ..... do. & .0 & 12.2 & 6.1 & 85 & 98 & 183 \\
\hline 230 & .....do......... & 4.00 & .....do. & 4.6 & 2.3 & .8 & 48 & & 48 \\
\hline 231 & .....do......... & 4.00 & .....do. & 1.2 & 11.5 & 5.8 & 89 & 93 & 182 \\
\hline 232 & .....do... & 3.90 & .....do.. & 1.5 & 6.5 & 10.8 & 56 & 173 & 229 \\
\hline 212 & .....do......... & 2.50 & Very scattering.... & .6 & 5. 6 & 2.5 & 44 & 40 & 84 \\
\hline 214 & ....do......... & 2.50 & .....do................ & .0 & 2.8 & 1.9 & 20 & 30 & 50 \\
\hline 215 & .....do... & 2.00 & .....do. & .0 & 1.5 & 3.0 & 11 & 48 & 59 \\
\hline 216 & ......do.... & 2.50 & ......do.. & .0 & .6 & 3.1 & 4 & 50 & 54 \\
\hline 217 & .....do... & 3. 00 & .....do. & .0 & .0 & 2.9 & 0 & 46 & 46 \\
\hline 218 & .....do......... & 3.00 & ....do.do. & 3.0 & 5.2 & 2.6 & 57 & 42 & 99 \\
\hline 220 & .....do.......... & 2.50 & .....do.. & .0 & 4.2 & 2.8 & 29 & 45 & 74 \\
\hline 221 & .....do.... & 1.50 & .....do.. & .0 & 1.8 & 4.5 & 13 & 72 & 85 \\
\hline 226 & ....do.......... & 2. 00 & ....do.. & .8 & 3.8 & 4.3 & 32 & 69 & 101 \\
\hline 227 & ......do... & 3.00 & ....do. & .0 & 3.2 & 1.9 & 22 & 30 & 52 \\
\hline 233 & .....do......... & 4.00 & …do. & 1.9 & 4.2 & 2.3 & 43 & 37 & 80 \\
\hline 219 & .....do.......... & 3.00 & Depleted... & .0 & 6.5 & 1.0 & 46 & 16 & 62 \\
\hline 223 & .....do... & .50 & .....do.. & .0 & 2.8 & 1.1 & 20 & 18 & 38 \\
\hline 224 & .....do... & .50 & ..... do.. & .0 & .0 & .0 & 0 & 0 & 0 \\
\hline 228 & .....do.... & 4.00 & ..... do. & .0 & 3.5 & .8 & 25 & 13 & 38 \\
\hline 234 & ......do.... & 4.00 & .....do. & 7.3 & 6.1 & .4 & 94 & 6 & 100 \\
\hline 235 & .....do.... & 4.50 & ...do. & .0 & .0 & .0 & 0 & 0 & 0 \\
\hline 236 & do & 4.00 & ...do. & .8 & 1.9 & .4 & 19 & 6 & 25 \\
\hline 237 & ..do... & 3.00 & ...do. & 10.7 & 12.0 & 1.0 & 160 & 16 & 176 \\
\hline 238 & ....do.......... & 4.00 & ...do.. & 5.8 & 3.5 & 1.2 & 65 & 19 & 84 \\
\hline 344 & Dec. 15,1910 & .90 & ...do. & .0 & .0 & .0 & 0 & 0 & 0 \\
\hline 345 & ..... do.......... & 1.20 & ... do. & 3.1 & 24.4 & .0 & 193 & 0 & 193 \\
\hline 346 & .....do... & 2. 30 & .. do . & 3.9 & 1.0 & .0 & 34 & 0 & 34 \\
\hline 347 & ..do.. & 2.30 & ..do & 1.9 & 1.0 & .0 & 20 & 0 & 20 \\
\hline 348 & do... & 1.00 & .00 & 2.5 & 4.7 & .0 & 51 & 0 & 51 \\
\hline 349 & .....do... & 1.30 & & .0 & 4.2 & .0 & 29 & $\mathbf{0}$ & 29 \\
\hline 350 & .....do.... & 2.30 & ..... do. & 1.0 & 1.3 & .0 & 16 & 0 & 16 \\
\hline
\end{tabular}


Detatls of Examination of Dauphin Island Bay-Continued.

\begin{tabular}{|c|c|c|c|c|c|c|c|c|c|}
\hline \multirow{2}{*}{$\begin{array}{l}\text { Angle } \\
\text { No. }\end{array}$} & \multirow{2}{*}{$\begin{array}{c}\text { Date of } \\
\text { examination. }\end{array}$} & \multirow{2}{*}{$\begin{array}{c}\text { Depth } \\
\text { of } \\
\text { water. }\end{array}$} & \multirow{2}{*}{ Character of growth. } & \multicolumn{3}{|c|}{$\begin{array}{l}\text { Oysters caught per } \\
\text { square yard. }\end{array}$} & \multicolumn{3}{|c|}{$\begin{array}{c}\text { Estimated quantity oys- } \\
\text { ters per acre. }\end{array}$} \\
\hline & & & & Spat. & Culls. & Counts. & Seed. & Market. & Total. \\
\hline & & Feet. & & & & & Bush. & Bush. & Bush. \\
\hline $\begin{array}{l}351 \\
352\end{array}$ & 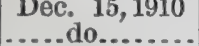 & $\begin{array}{l}3.30 \\
1.00\end{array}$ & \begin{tabular}{|} 
Depleted $\ldots \ldots$ \\
$\ldots$ do $\ldots$. . .
\end{tabular} & $\begin{array}{l}2.0 \\
1.4\end{array}$ & $\begin{array}{l}10.8 \\
16.9\end{array}$ & $\begin{array}{r}0.5 \\
.0\end{array}$ & $\begin{array}{r}90 \\
128\end{array}$ & $\begin{array}{l}8 \\
0\end{array}$ & $\begin{array}{r}98 \\
128\end{array}$ \\
\hline 353 & .... do......... & 2.10 & .... do do............. & 4.5 & 5.8 & .3 & 72 & 5 & 77 \\
\hline 354 & .....do... & 1.00 & $\ldots .$. do ............. & 1.9 & 7.2 & .3 & 64 & 5 & 69 \\
\hline 355 & ......do.... & 1.40 & ..... do & 1.8 & 5.5 & .3 & 51 & 5 & 56 \\
\hline 356 & $\ldots$........ & 4.00 & ..... do ................ & 4.0 & 2.5 & .0 & 46 & 0 & 46 \\
\hline 357 & $\ldots . .$. do.... & 4.00 & ..... do ............. & .5 & 8.5 & .0 & 70 & 0 & 70 \\
\hline 358 & $\ldots . .$. do.... & 5.00 & .... do............. & .0 & .0 & .0 & 0 & 0 & 0 \\
\hline 359 & $\ldots . .$. do.... & 4. 50 & .... do do............. & 5.0 & 3.9 & .6 & 62 & 10 & 72 \\
\hline 360 & ......do.... & 4.80 & $\ldots$ do $\ldots \ldots$ & 7.5 & 3.8 & .0 & 79 & 0 & 79 \\
\hline 361 & $\ldots$.... do........ & 3. 60 & .... do do........... & .0 & .3 & .0 & 2 & 0 & 2 \\
\hline 362 & $\ldots d 0 \ldots . . . . .$. & 1.00 & ..... do............. & .0 & 36 & .0 & 25 & 0 & 25 \\
\hline 363 & $\ldots . . . d 0 \ldots . . . . .$. & 1.30 & ..... do ............ & .6 & 8.3 & .0 & 62 & 0 & 62 \\
\hline 364 & $\ldots$............ & 4.30 & ....dodo............ & .0 & 3.0 & .0 & 21 & 0 & 21 \\
\hline 365 & ....do.... & 3.40 & .... do ................ & 1.4 & 2.3 & .0 & 27 & 0 & 27 \\
\hline 367 & ....do.... & 4.20 & ..... do do............ & .0 & 1.5 & .0 & 11 & 0 & 11 \\
\hline 368 & $\ldots$ do... & 5.30 & $\ldots .$. do ... & .0 & .0 & .0 & 0 & 0 & 0 \\
\hline 369 & ....do.... & 3.10 & .... do do............ & 6.2 & 11.2 & .0 & 122 & 0 & 122 \\
\hline 370 & .....do... & 4. 10 & ..... do... & 7.5 & 5.0 & .0 & 87 & 0 & 87 \\
\hline 371 & ....do... & 5. 10 & ..... do ......... & .0 & 0 & .0 & 0 & 0 & 0 \\
\hline 372 & ...... do... & 5. 60 & .... do do ............. & .0 & 4.0 & .0 & 28 & 0 & 28 \\
\hline 373 & .....do... & 3.50 & .... do do............ & 0 & 2.3 & .0 & 16 & 0 & 16 \\
\hline 375 & ..... do... & 5.50 & ..... do do............ & 4.0 & .0 & .0 & 28 & 0 & 28 \\
\hline 376 & .....do... & 5.50 & ....do............. & 2.0 & .7 & .0 & 19 & 0 & 19 \\
\hline 377 & .....do... & 5.40 & $\ldots$ do $\ldots . . . .$. & 6.0 & 6.0 & .0 & 84 & 0 & 84 \\
\hline 378 & .....do.... & 3.70 & ..... do do............ & 8.2 & .9 & .5 & 64 & 8 & 72 \\
\hline 379 & .....do... & 3.10 & ..... do.......... & 7.1 & 1.3 & .0 & 59 & 0 & 59 \\
\hline 380 & do... & 5.50 & . . . do... & .0 & 0 & 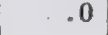 & 0 & 0 & 0 \\
\hline
\end{tabular}

\section{SPRINKEIS BAY.}

There are practically no market oysters in this bay, but small ones in clusters are scattered over the bottom. There were many dead oysters at the time of examination. The following tables exhibit all that it is necessary to say concerning this region:

\section{Oyster Growth in Sprinkels Bay.}

\begin{tabular}{|c|c|c|c|c|c|c|}
\hline \multirow{2}{*}{ Character of oyster growth. } & \multirow{2}{*}{ Area. } & \multicolumn{2}{|c|}{ Oysters per acre. } & \multicolumn{3}{|c|}{ Estimated content of oysters. } \\
\hline & & $\begin{array}{l}\text { Under } 3 \\
\text { inches. }\end{array}$ & $\begin{array}{l}\text { Over } 3 \\
\text { inches. }\end{array}$ & Seed. & Market. & Total. \\
\hline Depleted.. & $\begin{array}{r}\text { Acres. } \\
133\end{array}$ & $\begin{array}{r}\text { Bushels. } \\
60\end{array}$ & $\begin{array}{r}\text { Bushels. } \\
1\end{array}$ & $\begin{array}{r}\text { Bushels. } \\
7,980\end{array}$ & $\begin{array}{r}\text { Bushels. } \\
133\end{array}$ & $\begin{array}{r}\text { Bushels. } \\
8,113\end{array}$ \\
\hline
\end{tabular}

Detalls of Examination of Sprinkels Bay.

\begin{tabular}{|c|c|c|c|c|c|c|c|c|c|}
\hline \multirow{2}{*}{$\begin{array}{l}\text { Angle } \\
\text { No. }\end{array}$} & \multirow{2}{*}{$\begin{array}{c}\text { Date of } \\
\text { examination. }\end{array}$} & \multirow{2}{*}{$\begin{array}{l}\text { Depth } \\
\text { of } \\
\text { water. }\end{array}$} & \multirow{2}{*}{ Character of growth. } & \multicolumn{3}{|c|}{$\begin{array}{l}\text { Oysters caught per } \\
\text { square yard. }\end{array}$} & \multicolumn{3}{|c|}{$\begin{array}{c}\text { Estimated quantity oys- } \\
\text { ters per acre. }\end{array}$} \\
\hline & & & & Spat. & Culls. & Counts. & Seed. & Market. & Total. \\
\hline $\begin{array}{l}366 \\
374 \\
396 \\
397 \\
398 \\
399 \\
400 \\
401\end{array}$ & 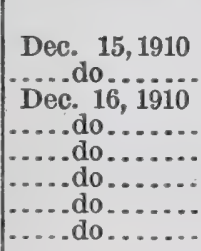 & $\begin{array}{r}\text { Feet. } \\
1.10 \\
3.00 \\
1.00 \\
3.00 \\
1.00 \\
2.00 \\
1.10 \\
3.00\end{array}$ & 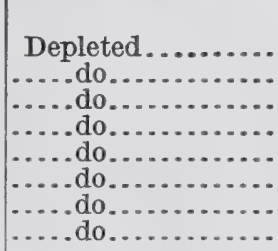 & $\begin{array}{r}0.0 \\
2.9 \\
.3 \\
1.3 \\
.0 \\
1.6 \\
.0 \\
4.5\end{array}$ & $\begin{array}{r}17.0 \\
4.2 \\
13.6 \\
.0 \\
3.9 \\
13.6 \\
.0 \\
5.4\end{array}$ & $\begin{array}{l}0.3 \\
.0 \\
.3 \\
.0 \\
.0 \\
.0 \\
.0 \\
.0\end{array}$ & $\begin{array}{r}\text { Bush. } \\
119 \\
50 \\
97 \\
9 \\
27 \\
106 \\
0 \\
69\end{array}$ & $\begin{array}{r}\text { Bush. } \\
5 \\
0 \\
5 \\
0 \\
0 \\
0 \\
0 \\
0\end{array}$ & $\begin{array}{r}\text { Bush. } \\
124 \\
50 \\
102 \\
9 \\
27 \\
106 \\
0 \\
69\end{array}$ \\
\hline
\end{tabular}




\section{COLLIER BAY.}

The oysters here, which are practically all small, are scattered in clusters along most of the shore of the bay. The bottom is mainly soft mud, with considerable grass in places. The percentage of dead spat and small oysters is large. The following tables give the data obtained in this bay:

\section{Oyster Growth in Collier Bay.}

\begin{tabular}{|c|c|c|c|c|c|c|}
\hline \multirow[b]{2}{*}{ Character of oyster growth. } & \multirow[b]{2}{*}{ Area. } & \multicolumn{2}{|c|}{ Oysters per acre. } & \multicolumn{3}{|c|}{ Estimated content of oysters. } \\
\hline & & $\begin{array}{l}\text { Under } 3 \\
\text { inches. }\end{array}$ & $\begin{array}{l}\text { Over } 3 \\
\text { inches. }\end{array}$ & Seed. & Market. & Total. \\
\hline Depleted... & $\begin{array}{r}\text { Acres. } \\
13\end{array}$ & $\begin{array}{r}\text { Bushels. } \\
57\end{array}$ & $\begin{array}{r}\text { Bushels. } \\
2\end{array}$ & $\begin{array}{r}\text { Bushels. } \\
741\end{array}$ & $\begin{array}{r}\text { Bushels. } \\
26\end{array}$ & $\begin{array}{r}\text { Bushels. } \\
767\end{array}$ \\
\hline
\end{tabular}

Detams of Examination of Collier Bay.

\begin{tabular}{|c|c|c|c|c|c|c|c|c|c|}
\hline \multirow{2}{*}{$\begin{array}{l}\text { Angle } \\
\text { No. }\end{array}$} & \multirow{2}{*}{$\begin{array}{c}\text { Date of } \\
\text { examination. }\end{array}$} & \multirow{2}{*}{$\begin{array}{l}\text { Depth } \\
\text { of } \\
\text { water. }\end{array}$} & \multirow{2}{*}{ Chargeter of growth. } & \multicolumn{3}{|c|}{$\begin{array}{l}\text { Oysters caught per } \\
\text { square yard. }\end{array}$} & \multicolumn{3}{|c|}{$\begin{array}{l}\text { Estimated quantity oys- } \\
\text { ters per acre. }\end{array}$} \\
\hline & & & & Spat. & Culls. & Counts. & Seed. & Market. & Total. \\
\hline $\begin{array}{l}407 \\
408 \\
409\end{array}$ & $\begin{array}{c}\text { Dec. } 16,1910 \\
\ldots \ldots . \text { do } \ldots \ldots \ldots \\
\ldots . \text { do } \ldots \ldots . . .\end{array}$ & $\begin{array}{r}\text { Feet. } \\
100 \\
3.00 \\
1.20\end{array}$ & 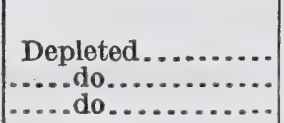 & $\begin{array}{r}0.0 \\
.0 \\
.0\end{array}$ & $\begin{array}{r}5.3 \\
.8 \\
18.3\end{array}$ & $\begin{array}{l}0.3 \\
.0 \\
.0\end{array}$ & $\begin{array}{r}\text { Bush. } \\
37 \\
6 \\
128\end{array}$ & $\begin{array}{r}\text { Bush. } \\
5 \\
0 \\
0\end{array}$ & $\begin{array}{r}\text { Bush. } \\
42 \\
6 \\
128\end{array}$ \\
\hline
\end{tabular}

\section{OFF EAST BASE SIGNAL.}

This is a very small patch on a point west of Collier Bay, which among considerable débris contains a few scattering clusters of four or five small sharp-edged oysters each.

Oygter Growth off East Base Signal.

\begin{tabular}{|c|c|c|c|c|c|c|}
\hline \multirow{2}{*}{ Character of oyster growth. } & \multirow{2}{*}{ Area. } & \multicolumn{2}{|c|}{ Oysters per acre. } & \multicolumn{3}{|c|}{ Fstimated content of oysters. } \\
\hline & & $\begin{array}{l}\text { Under } 3 \\
\text { inches. }\end{array}$ & $\begin{array}{l}\text { Over } 3 \\
\text { inches. }\end{array}$ & Seed. & Market. & Total. \\
\hline Depleted. . & $\begin{array}{r}\text { Acres. } \\
3\end{array}$ & $\begin{array}{r}\text { Bushels. } \\
3\end{array}$ & $\begin{array}{r}\text { Bushels. } \\
0\end{array}$ & Bushels. & $\begin{array}{r}\text { Bushels. } \\
0\end{array}$ & Bushek. \\
\hline
\end{tabular}

Details of Examination of Point off East Base Signal.

\begin{tabular}{|c|c|c|c|c|c|c|c|c|c|}
\hline \multirow{2}{*}{$\begin{array}{l}\text { Angle } \\
\text { No. }\end{array}$} & \multirow{2}{*}{$\begin{array}{c}\text { Date of } \\
\text { examination. }\end{array}$} & \multirow{2}{*}{$\begin{array}{l}\text { Depth } \\
\text { of } \\
\text { water. }\end{array}$} & \multirow{2}{*}{ Character of growth. } & \multicolumn{3}{|c|}{$\begin{array}{l}\text { Oysters caught per } \\
\text { square yard. }\end{array}$} & \multicolumn{3}{|c|}{$\begin{array}{c}\text { Estimated quantity oys- } \\
\text { ters per acre. }\end{array}$} \\
\hline & & & & Spat. & Culls. & Counts. & Seed. & Market. & Total. \\
\hline $\begin{array}{l}405 \ldots \\
406 \ldots\end{array}$ & $\begin{array}{l}\text { Dec. } 16,1910 \\
\ldots \ldots \text { do........ }\end{array}$ & $\begin{array}{c}\text { Feet. } \\
1.00 \\
1.00\end{array}$ & \begin{tabular}{|l} 
Depleted...... \\
..... do.......
\end{tabular} & $\begin{array}{r}0.8 \\
.0\end{array}$ & $\begin{array}{r}0.0 \\
.0\end{array}$ & $\begin{array}{r}0.0 \\
.0\end{array}$ & $\begin{array}{r}\text { Bush. } \\
6 \\
0\end{array}$ & $\begin{array}{c}\text { Bush. } \\
0 \\
0\end{array}$ & Bush. \\
\hline
\end{tabular}




\section{HALF-MOON PATCHES.}

This name, which is not used by the oystermen, serves to designate a number of small areas of oyster growth lying west of the lower end of Cedar Point. Most of these patches are not more than an acre or two in extent and bear scattering growth or are depleted. They generally lie on a soft muddy bottom, but there is a hard reef on which the water shoals to a minimum of $1 \frac{1}{2}$ feet about 500 or 600 yards west of the extreme end of Cedar Point.

The following tables exhibit the area and condition of these patches.

Oyster Growth on Half-Moon Patches.

\begin{tabular}{|c|c|c|c|c|c|c|}
\hline \multirow{2}{*}{ Character of oyster growth. } & \multirow{2}{*}{ Area. } & \multicolumn{2}{|c|}{ Oysters per acre. } & \multicolumn{3}{|c|}{ Estimated content of oysters. } \\
\hline & & $\begin{array}{l}\text { Under } 3 \\
\text { inches. }\end{array}$ & $\begin{array}{c}\text { Over } 3 \\
\text { inckes. }\end{array}$ & Seed. & Market. & Total. \\
\hline $\begin{array}{l}\text { Dense ........... } \\
\text { Very scattering } \\
\text { Depleted........ }\end{array}$ & $\begin{array}{r}\text { Acres. } \\
2 \\
8 \\
4\end{array}$ & $\begin{array}{r}\text { Bushels. } \\
8 \\
13 \\
60\end{array}$ & $\begin{array}{r}\text { Bushels. } \\
154 \\
55 \\
0\end{array}$ & $\begin{array}{r}\text { Bushels. } \\
16 \\
104 \\
240\end{array}$ & $\begin{array}{r}\text { Bushels. } \\
308 \\
440 \\
0\end{array}$ & $\begin{array}{r}\text { Bushels. } \\
324 \\
544 \\
240\end{array}$ \\
\hline Total. . & 14 & $\cdots$ & $\cdots$ & 360 & 748 & 1,108 \\
\hline
\end{tabular}

Detalls of Examination of Half-Moon Patches.

\begin{tabular}{|c|c|c|c|c|c|c|c|c|c|}
\hline \multirow{2}{*}{$\begin{array}{l}\text { Angle } \\
\text { No. }\end{array}$} & \multirow{2}{*}{$\begin{array}{c}\text { Date of } \\
\text { examination. }\end{array}$} & \multirow{2}{*}{$\begin{array}{c}\text { Depth } \\
\text { of } \\
\text { water. }\end{array}$} & \multirow{2}{*}{ Character of growth. } & \multicolumn{3}{|c|}{$\begin{array}{l}\text { Oysters caught per } \\
\text { square yard. }\end{array}$} & \multicolumn{3}{|c|}{$\begin{array}{c}\text { Estimated quantity oys- } \\
\text { ters per acre. }\end{array}$} \\
\hline & & & & Spat. & Culls. & Counts. & Seed. & Market. & Total. \\
\hline $\begin{array}{l}263 \\
466 \\
465 \\
464 \\
462 \\
460 \\
459\end{array}$ & 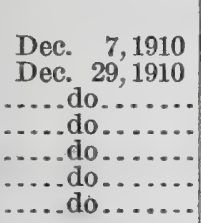 & $\begin{array}{r}\text { Feet. } \\
\text { 4. } 00 \\
6.00 \\
6.00 \\
5.00 \\
4.50 \\
4.00 \\
3.50\end{array}$ & 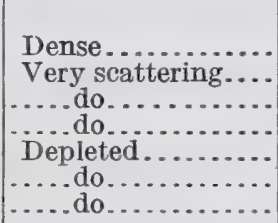 & $\begin{array}{r}0.0 \\
.0 \\
.0 \\
.0 \\
3.5 \\
1.8\end{array}$ & $\begin{array}{r}4.3 \\
.0 \\
1.2 \\
1.7 \\
14.5 \\
4.1\end{array}$ & $\begin{array}{l}4.3 \\
2.9 \\
3.1 \\
.0 \\
.0 \\
.0\end{array}$ & $\begin{array}{r}\text { Bush. } \\
8 \\
31 \\
0 \\
8 \\
12 \\
126 \\
41\end{array}$ & $\begin{array}{r}\text { Bush. } \\
154 \\
69 \\
46 \\
50 \\
0 \\
0 \\
0\end{array}$ & $\begin{array}{r}\text { Bush. } \\
162 \\
100 \\
46 \\
58 \\
12 \\
126 \\
41\end{array}$ \\
\hline
\end{tabular}

HERON BAY, EAST SIDE.

On the east side of Heron Bay there is an area of oyster growth stretching along shore for nearly a mile south of the forks of the bay. It consists principally of depleted bottom in which there are shells more or less buried in the mud, with an occasional cluster of oysters. The area and character of the growth on the several parts of this bed are as follows:

Oyster Growth in Heron Bay, East Side.

\begin{tabular}{|c|c|c|c|c|c|c|}
\hline \multirow{2}{*}{ Character of oyster growth. } & \multirow{2}{*}{ Area. } & \multicolumn{2}{|c|}{ Oysters per acre. } & \multicolumn{3}{|c|}{ Estimated content of oysters. } \\
\hline & & $\begin{array}{l}\text { Under } 3 \\
\text { inches. }\end{array}$ & $\begin{array}{l}\text { Over } 3 \\
\text { inches. }\end{array}$ & Seed. & Market. & Total. \\
\hline $\begin{array}{l}\text { Dense........... } \\
\text { Scattering...... } \\
\text { Very scattering } \\
\text { Depleted....... }\end{array}$ & $\begin{array}{r}\text { Acres. } \\
34 \\
11 \\
5 \\
52\end{array}$ & $\begin{array}{r}\text { Bushels. } \\
101 \\
13 \\
110 \\
0\end{array}$ & $\begin{array}{r}\text { Bushels. } \\
190 \\
96 \\
72 \\
0\end{array}$ & $\begin{array}{r}\text { Bushels. } \\
3,434 \\
143 \\
550 \\
0\end{array}$ & $\begin{array}{r}\text { Bushels. } \\
6,460 \\
1,056 \\
360 \\
0\end{array}$ & $\begin{array}{r}\text { Bushels. } \\
9,894 \\
1,199 \\
910 \\
0\end{array}$ \\
\hline Total. . & 102 & 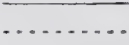 & $\ldots$ & 4,127 & 7,876 & 12,003 \\
\hline
\end{tabular}


There is an area of dense growth at the northern end of the bed, apparently extending on to the planted bottom inside of the northeast arm of the bay. These oysters are in small clusters and are of good size and fair shape and quality. There is another dense patch near the southern end of the bed, where the oysters are smaller and inferior.

The scattering growth lies in a narrow strip along the western edge of the southern half of the bed. The bottom consists in large part of firm mud and shells lying in a substratum of soft mud. The very scattering growth lies in a small patch near the southern inshore part of the bed and the depleted area stretches nearly the entire length of the bed and for a considerable distance comprises its entire width. The following examinations were made:

Detalls of Examination of Heron Bay, East Stme.

\begin{tabular}{|c|c|c|c|c|c|c|c|c|c|}
\hline \multirow{2}{*}{$\begin{array}{l}\text { Angle } \\
\text { No. }\end{array}$} & \multirow{2}{*}{$\begin{array}{c}\text { Date of } \\
\text { examination. }\end{array}$} & \multirow{2}{*}{$\begin{array}{c}\text { Depth } \\
\text { of } \\
\text { water. }\end{array}$} & \multirow{2}{*}{ Character of growth. } & \multicolumn{3}{|c|}{$\begin{array}{l}\text { Oysters caught per } \\
\text { square yard. }\end{array}$} & \multicolumn{3}{|c|}{$\begin{array}{l}\text { Estimated quantity oys- } \\
\text { ters per acre. }\end{array}$} \\
\hline & & & & Spat. & Culls. & Counts. & Seed. & Market. & Total. \\
\hline $\begin{array}{l}507 \\
508 \\
516 \\
418 \\
515 \\
417 \\
416\end{array}$ & $\begin{array}{l}\text { Jan. } 1,1911 \\
\ldots \ldots \text { do........ } \\
\text { Dec. } 21,1910 \\
\text { Jan. } 1,1911 \\
\text { Dec. 21, } 1910 \\
\ldots . \text {..do........ }\end{array}$ & \begin{tabular}{r|} 
Feet. \\
3.0 \\
4.9 \\
4.0 \\
4.0 \\
4.3 \\
3.6 \\
3.6
\end{tabular} & 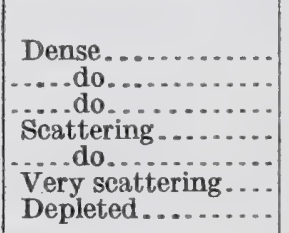 & $\begin{array}{l}2.1 \\
.0 \\
.0 \\
.5 \\
.0 \\
.0 \\
.0\end{array}$ & $\begin{array}{r}16.3 \\
11.2 \\
13.5 \\
.0 \\
3.0 \\
15.8 \\
.0\end{array}$ & $\begin{array}{r}14.2 \\
10.0 \\
11.5 \\
5.0 \\
7.0 \\
4.5 \\
.0\end{array}$ & $\begin{array}{r}\text { Bush. } \\
129 \\
78 \\
95 \\
4 \\
21 \\
110 \\
0\end{array}$ & $\begin{array}{r}\text { Bush. } \\
227 \\
160 \\
184 \\
80 \\
112 \\
72 \\
0\end{array}$ & $\begin{array}{r}\text { Bush. } \\
356 \\
238 \\
279 \\
84 \\
133 \\
182 \\
0\end{array}$ \\
\hline
\end{tabular}

HERON BAY, WEST SIDE.

The oyster growth on the western, or, more accurately, on the northwestern, side of Heron Bay stretches along shore for a distance of upward of one-half mile from the mouth of northwest arm.

The following table exhibits the area, density of oyster growth, and estimated total content of oysters:

Oyster Growth in Heron Bay, West Side.

\begin{tabular}{|c|c|c|c|c|c|c|}
\hline \multirow{2}{*}{ Character of oyster growth. } & \multirow{2}{*}{ Area. } & \multicolumn{2}{|c|}{ Oysters per acre. } & \multicolumn{3}{|c|}{ Estimated content of oysters. } \\
\hline & & $\begin{array}{l}\text { Under } 3 \\
\text { inches. }\end{array}$ & $\begin{array}{l}\text { Over } 3 \\
\text { inches. }\end{array}$ & Seed. & Market. & Total. \\
\hline $\begin{array}{l}\text { Dense....... } \\
\text { Depleted... }\end{array}$ & $\begin{array}{r}\text { Acres. } \\
31 \\
21\end{array}$ & $\begin{array}{r}\text { Bushels. } \\
54 \\
4\end{array}$ & $\begin{array}{r}\text { Bushels. } \\
245 \\
10\end{array}$ & $\begin{array}{r}\text { Bushels. } \\
1,674 \\
84\end{array}$ & $\begin{array}{r}\text { Bushels. } \\
7,595 \\
210\end{array}$ & $\begin{array}{r}\text { Bushels. } \\
9,269 \\
294\end{array}$ \\
\hline Total. . & 52 & . & ......... & 1,758 & 7,805 & 9,563 \\
\hline
\end{tabular}

The area of dense growth lies at the northeast end of the bed on a very hard sand and shell bottom, gradually becoming softer toward the depleted bottom. The oysters are elongated, sharp edged, and in rather heavy clusters, bearing a few mussels. 
The depleted bottom consists partly of soft mud, partly sand, and in places 3 inches of the former overlying a substratum of the latter. The following examinations were made on this bed.

Details of Examination of Heron Bay, West Side.

\begin{tabular}{|c|c|c|c|c|c|c|c|c|c|}
\hline \multirow{2}{*}{$\begin{array}{l}\text { Angle } \\
\text { No. }\end{array}$} & \multirow{2}{*}{$\begin{array}{l}\text { Date of } \\
\text { examination. }\end{array}$} & \multirow{2}{*}{$\begin{array}{l}\text { Depth } \\
\text { of } \\
\text { water. }\end{array}$} & \multirow{2}{*}{ Character of growth. } & \multicolumn{3}{|c|}{$\begin{array}{l}\text { Oysters caught per } \\
\text { square yard. }\end{array}$} & \multicolumn{3}{|c|}{$\begin{array}{l}\text { Estimated quantity oys- } \\
\text { ters per acre. }\end{array}$} \\
\hline & & & & Spat. & Culls. & Counts. & Seed. & Market. & Total. \\
\hline $\begin{array}{l}504 \\
509 \\
510 \\
514\end{array}$ & 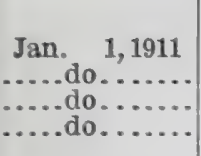 & $\begin{array}{r}\text { Feet. } \\
3.2 \\
3.4 \\
3.1 \\
4.5\end{array}$ & 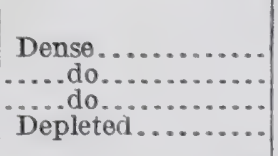 & $\begin{array}{r}0.0 \\
.0 \\
.0 \\
.0\end{array}$ & $\begin{array}{r}6.2 \\
15.9 \\
.8 \\
.6\end{array}$ & $\begin{array}{r}15.0 \\
20.9 \\
10.0 \\
.6\end{array}$ & $\begin{array}{r}\text { Bush. } \\
44 \\
111 \\
6 \\
4\end{array}$ & $\begin{array}{r}\text { Bush. } \\
240 \\
334 \\
160 \\
10\end{array}$ & $\begin{array}{r}\text { Bush. } \\
284 \\
445 \\
166 \\
14\end{array}$ \\
\hline
\end{tabular}

Lying in the middle of Heron Bay is a long, narrow bed of planted oysters, continuous at its northern end with what appears to be a natural scattering growth. It is probable that this whole area is on an old bed.

\section{HERON BAY, NORTHWEST ARM.}

It was understood that the northeastern arm of Heron Bay is comprised within the limits of private ownership, is used for purposes of oyster culture, and contains no public beds. For that reason it was not examined. Northwest Arm is public bottom, but contains very few oysters of value. The following table shows the area, density of oyster growth, and total contents:

Oyster Growth in Heron Bay, Northwest Arm.

\begin{tabular}{|c|c|c|c|c|c|c|}
\hline \multirow{2}{*}{ Character of oyster growth. } & \multirow{2}{*}{ Area. } & \multicolumn{2}{|c|}{ Oysters per acre. } & \multicolumn{3}{|c|}{ Estimated content of oysters. } \\
\hline & & $\begin{array}{l}\text { Under } 3 \\
\text { inches. }\end{array}$ & $\begin{array}{l}\text { Over } 3 \\
\text { inches. }\end{array}$ & Eseed. & Market. & Total. \\
\hline $\begin{array}{l}\text { Scattering........ } \\
\text { Depleted......... }\end{array}$ & $\begin{array}{r}\text { Acres. } \\
16 \\
42 \\
\end{array}$ & $\begin{array}{r}\text { Bushels. } \\
40 \\
10 \\
\end{array}$ & $\begin{array}{r}\text { Bushels. } \\
119 \\
17 \\
\end{array}$ & $\begin{array}{r}\text { Bushels. } \\
640 \\
420\end{array}$ & $\begin{array}{r}\text { Bushels. } \\
1,904 \\
714\end{array}$ & $\begin{array}{r}\text { Bushels. } \\
2,544 \\
1,134\end{array}$ \\
\hline Total... & 58 & 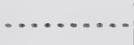 & . & 1,060 & 2,618 & 3,678 \\
\hline
\end{tabular}

The area of scattering growth lies as a strip along shore at the eastern side of the mouth of the arm. The market oysters on this area are rather large and some of them of good shape and quality. The depleted bottom stretches from shore to shore in the upper part and continues as a strip along the western shore in the lower half of the arm. The oysters, of which a fair proportion are of good size, lie in clusters on a bottom of soft or very soft mud in which there are many buried shells. The indications are that this body of water would produce good oysters if a firm surface could be prorided by the use of sand and shells. 


\section{The following observations were made:}

Details of Examination of Northwest Arm, Heron Bay.

\begin{tabular}{|c|c|c|c|c|c|c|c|c|c|}
\hline \multirow{2}{*}{$\begin{array}{l}\text { Angle } \\
\text { No. }\end{array}$} & \multirow{2}{*}{$\begin{array}{l}\text { Date of } \\
\text { examination. }\end{array}$} & \multirow{2}{*}{$\begin{array}{l}\text { Depth } \\
\text { of } \\
\text { water. }\end{array}$} & \multirow{2}{*}{ Character of growth. } & \multicolumn{3}{|c|}{$\begin{array}{l}\text { Oysters caught per } \\
\text { square yard. }\end{array}$} & \multicolumn{3}{|c|}{$\begin{array}{c}\text { Estimated quantity oys- } \\
\text { ters per acre. }\end{array}$} \\
\hline & & & & Spat. & Culls. & Counts. & Seed. & Market. & Total. \\
\hline $\begin{array}{l}502 \\
505 \\
498 \\
499 \\
501\end{array}$ & 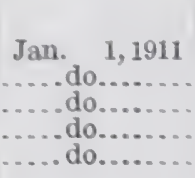 & $\begin{array}{r}\text { Feet. } \\
1.8 \\
4.2 \\
1.9 \\
1.5 \\
1.8\end{array}$ & $\begin{array}{l}\text { Seattering. } \\
\text { Deplo....... } \\
\ldots . . \text { do...... } \\
\ldots . . \text { do.... }\end{array}$ & $\begin{array}{l}0.0 \\
.0 \\
.0 \\
.0 \\
.0\end{array}$ & $\begin{array}{r}10.0 \\
1.5 \\
.9 \\
1.2 \\
2.3\end{array}$ & $\begin{array}{l}7.8 \\
7.0 \\
.0 \\
1.5 \\
1.6\end{array}$ & $\begin{array}{r}\text { Bush. } \\
70 \\
10 \\
6 \\
8 \\
16\end{array}$ & $\begin{array}{r}\text { Bush. } \\
125 \\
112 \\
0 \\
24 \\
26\end{array}$ & $\begin{array}{r}\text { Bush. } \\
195 \\
122 \\
6 \\
32 \\
42\end{array}$ \\
\hline
\end{tabular}

MIDDLE GROUND, FOWL RIVER BAY.

This consists of a small reef of dense growth, with an area of very scattered oysters extending from it toward the head of the bay. The area shown in the following table includes in addition that portion of what appears to be a private bed more than 600 yards from the shore.

The area, density of oyster growth, and estimated contents are shown in the following tables:

Oyster Growth in Middle Ground, Fowl River Bay.

\begin{tabular}{|c|c|c|c|c|c|c|}
\hline \multirow{2}{*}{ Character of oyster growth. } & \multirow{2}{*}{ Area. } & \multicolumn{2}{|c|}{ Oysters per acre. } & \multicolumn{3}{|c|}{ Estimated content of oysters. } \\
\hline & & $\begin{array}{l}\text { Under } 3 \\
\text { inches. }\end{array}$ & $\begin{array}{l}\text { Over } 3 \\
\text { inches. }\end{array}$ & Seed. & Market. & Total. \\
\hline $\begin{array}{l}\text { Dense.............. } \\
\text { Very scattering... }\end{array}$ & $\begin{array}{r}\text { Acres. } \\
12 \\
40\end{array}$ & $\begin{array}{r}\text { Bushels. } \\
93 \\
107\end{array}$ & $\begin{array}{r}\text { Bushels. } \\
204 \\
58\end{array}$ & $\begin{array}{r}\text { Bushels. } \\
116 \\
4,280\end{array}$ & $\begin{array}{r}\text { Bushels. } \\
2,448 \\
2,320\end{array}$ & $\begin{array}{r}\text { Bushels. } \\
2,564 \\
6,600\end{array}$ \\
\hline Total.... & 52 & . & & 4,396 & 4,768 & 9,164 \\
\hline
\end{tabular}

Details of Examination of Middle Ground, Fowl Rryer Bay.

\begin{tabular}{|c|c|c|c|c|c|c|c|c|c|}
\hline \multirow{2}{*}{$\begin{array}{l}\text { Angle } \\
\text { No. }\end{array}$} & \multirow{2}{*}{$\begin{array}{c}\text { Date of } \\
\text { examination. }\end{array}$} & \multirow{2}{*}{$\begin{array}{l}\text { Depth } \\
\text { of } \\
\text { water. }\end{array}$} & \multirow{2}{*}{ Character of growth. } & \multicolumn{3}{|c|}{$\begin{array}{l}\text { Oysters caught per } \\
\text { square yard. }\end{array}$} & \multicolumn{3}{|c|}{$\begin{array}{c}\text { Estimated quantity oys- } \\
\text { ters per acre. }\end{array}$} \\
\hline & & & & Spat. & Culls. & Counts. & Seed. & Market. & Total. \\
\hline $\begin{array}{l}637 \\
640 \\
638 \\
639\end{array}$ & 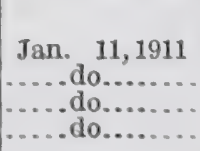 & $\begin{array}{r}\text { Feet. } \\
4.0 \\
4.3 \\
3.5 \\
4.0\end{array}$ & 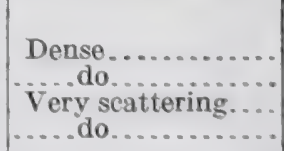 & $\begin{array}{r}0.0 \\
.0 \\
.0 \\
1.5\end{array}$ & $\begin{array}{r}9.5 \\
17.0 \\
19.0 \\
10.0\end{array}$ & $\begin{array}{r}14.5 \\
11.0 \\
2.7 \\
4.5\end{array}$ & $\begin{array}{r}\text { Bush. } \\
66.5 \\
119.0 \\
133.0 \\
80.5\end{array}$ & $\begin{array}{r}\text { Bush. } \\
232.0 \\
176.0 \\
43.2 \\
72.0\end{array}$ & $\begin{array}{r}\text { Bush. } \\
298.5 \\
295.0 \\
176.2 \\
152.5\end{array}$ \\
\hline
\end{tabular}

\section{GRASSY ISLAND.}

This is a small patch running from the north side of Grassy Island to a depth of about 1 foot. It is apparently an old bar, but is at present of very little value, as is shown in the following table: 
Oyster Growth on Grassy Island.

\begin{tabular}{|c|c|c|c|c|c|c|}
\hline \multirow{2}{*}{ Character of oyster growth. } & \multirow{2}{*}{ Area. } & \multicolumn{2}{|c|}{ Oysters per acre. } & \multicolumn{3}{|c|}{ Estimated content of oysters. } \\
\hline & & $\begin{array}{l}\text { Under } 3 \\
\text { inches. }\end{array}$ & $\begin{array}{l}\text { Over } 3 \\
\text { inches. }\end{array}$ & Seed. & Market. & Total. \\
\hline Depleted.. & Acres. & $\begin{array}{r}\text { Bushels. } \\
10\end{array}$ & $\begin{array}{r}\text { Bushels. } \\
13\end{array}$ & $\begin{array}{r}\text { Bushels. } \\
40\end{array}$ & $\begin{array}{r}\text { Bushels. } \\
52\end{array}$ & Bushels. \\
\hline
\end{tabular}

\section{Details of Examination of Grassy Island.}

\begin{tabular}{|c|c|c|c|c|c|c|c|c|c|}
\hline \multirow{2}{*}{$\begin{array}{l}\text { Angle } \\
\text { No. }\end{array}$} & \multirow{2}{*}{$\begin{array}{c}\text { Date of } \\
\text { examination. }\end{array}$} & \multirow{2}{*}{$\begin{array}{l}\text { Depth } \\
\text { of } \\
\text { water. }\end{array}$} & \multirow{2}{*}{ Character of growth. } & \multicolumn{3}{|c|}{$\begin{array}{l}\text { Oysters caught per } \\
\text { square yard. }\end{array}$} & \multicolumn{3}{|c|}{$\begin{array}{l}\text { Estimated quantity oys- } \\
\text { ters per acre. }\end{array}$} \\
\hline & & & & Spat. & Culls. & Counts. & Seed. & Market. & Total. \\
\hline 683 & Jan. 13,1911 & $\begin{array}{l}\text { Feet. } \\
0.8\end{array}$ & Depleted..... & 0.0 & 1.4 & 0.8 & $\begin{array}{r}\text { Bush. } \\
9.8\end{array}$ & $\begin{array}{l}\text { Bush. } \\
12.8\end{array}$ & $\begin{array}{l}\text { Bush. } \\
22.6\end{array}$ \\
\hline
\end{tabular}

\section{GOOSE BAYOU.}

This bed, consisting of a small area of dense growth, almost surrounded by very scattering oysters, is apparently included within a private claim, although there is no doubt that it is an old natural bed. There is a considerable proportion of large oysters of good shape. The area, character of oyster growth, and estimated content of the bed are as follows:

Oyster Growth in Goose Bayou.

\begin{tabular}{|c|c|c|c|c|c|c|}
\hline \multirow{2}{*}{ Character of oyster growth. } & \multirow{2}{*}{ Area. } & \multicolumn{2}{|c|}{ Oysters per acre. } & \multicolumn{3}{|c|}{ Estimated content of oysters. } \\
\hline & & $\begin{array}{l}\text { Under } 3 \\
\text { inches. }\end{array}$ & $\begin{array}{l}\text { Over } 3 \\
\text { inches. }\end{array}$ & Seed. & Market. & Total. \\
\hline $\begin{array}{l}\text { Dense............ } \\
\text { Very scattering.. }\end{array}$ & $\begin{array}{r}\text { Acres. } \\
5 \\
7\end{array}$ & $\begin{array}{r}\text { Bushels. } \\
76 \\
406\end{array}$ & $\begin{array}{r}\text { Bushels. } \\
286 \\
51\end{array}$ & $\begin{array}{r}\text { Bushels. } \\
380 \\
2,842\end{array}$ & $\begin{array}{r}\text { Bushels. } \\
1,430 \\
357\end{array}$ & $\begin{array}{r}\text { Bushels. } \\
1,810 \\
3,199\end{array}$ \\
\hline Total.. & 12 & & & 3,222 & 1,787 & 5,009 \\
\hline
\end{tabular}

Details of Examination of Goose Bayod.

\begin{tabular}{|c|c|c|c|c|c|c|c|c|c|}
\hline \multirow{2}{*}{$\begin{array}{l}\text { Angle } \\
\text { No. }\end{array}$} & \multirow{2}{*}{$\begin{array}{c}\text { Date of } \\
\text { examination. }\end{array}$} & \multirow{2}{*}{$\begin{array}{l}\text { Depth } \\
\text { of } \\
\text { water. }\end{array}$} & \multirow{2}{*}{ Character of growth. } & \multicolumn{3}{|c|}{$\begin{array}{l}\text { Oysters caught per } \\
\text { square yard. }\end{array}$} & \multicolumn{3}{|c|}{$\begin{array}{c}\text { Estimated quantity oys } \\
\text { ters per acre. }\end{array}$} \\
\hline & & & & Spat. & Culls. & Counts. & Seed. & Market. & Total. \\
\hline $\begin{array}{l}669 \\
671 \\
672\end{array}$ & $\begin{array}{c}\text { Jan. } 12,1911 \\
\ldots \ldots . \text { do } \ldots \ldots \ldots \\
\ldots \ldots \text { do........ }\end{array}$ & $\begin{array}{r}\text { Feet. } \\
1.5 \\
1.2 \\
1.5\end{array}$ & $\begin{array}{l}\text { Dense............ } \\
\text { Very scattering } \\
\text {......do............ }\end{array}$ & $\begin{array}{r}0.0 \\
2.2 \\
.0\end{array}$ & $\begin{array}{r}10.9 \\
7.6 \\
1.8\end{array}$ & $\begin{array}{r}17.9 \\
2.8 \\
3.6\end{array}$ & $\begin{array}{r}\text { Bush. } \\
76.3 \\
68.6 \\
12.6\end{array}$ & $\begin{array}{r}\text { Bush. } \\
286.4 \\
44.8 \\
57.6\end{array}$ & $\begin{array}{r}\text { Bush. } \\
362.7 \\
113.4 \\
70.2\end{array}$ \\
\hline
\end{tabular}




\section{SOUTHWEST OF VAN SIGNAL.}

This is a small patch of dense growth about 300 yards from shore. The oysters have a good shape, most of them are single, and at the time of examination were fat. Drills or borers were noted on the bed. The following tables show the results of the examination:

Oyster Growth Southwest of Van Signal.

\begin{tabular}{|c|c|c|c|c|c|c|}
\hline \multirow{2}{*}{ Character of oyster growth. } & \multirow{2}{*}{ Area. } & \multicolumn{2}{|c|}{ Oysters per acre. } & \multicolumn{3}{|c|}{ Estimated content of oysters. } \\
\hline & & $\begin{array}{l}\text { Under } 3 \\
\text { inches. }\end{array}$ & $\begin{array}{c}\text { Over } 3 \\
\text { inches. }\end{array}$ & Seed. & Market. & Total. \\
\hline Dense... & Acres. & $\begin{array}{r}\text { Bushels. } \\
70\end{array}$ & $\begin{array}{r}\text { Bushels. } \\
560\end{array}$ & $\begin{array}{r}\text { Bushels. } \\
70\end{array}$ & $\begin{array}{r}\text { Bushels. } \\
560\end{array}$ & $\begin{array}{r}\text { Bushels. } \\
630\end{array}$ \\
\hline
\end{tabular}

Details of Examination Southwest of Van Signal.

\begin{tabular}{|c|c|c|c|c|c|c|c|c|c|}
\hline \multirow{2}{*}{$\begin{array}{l}\text { Angle } \\
\text { No. }\end{array}$} & \multirow{2}{*}{$\begin{array}{l}\text { Date of } \\
\text { examination. }\end{array}$} & \multirow{2}{*}{$\begin{array}{l}\text { Depth } \\
\text { of } \\
\text { water. }\end{array}$} & \multirow{2}{*}{ Character of growth. } & \multicolumn{3}{|c|}{$\begin{array}{l}\text { Oysters caught per } \\
\text { square yard. }\end{array}$} & \multicolumn{3}{|c|}{$\begin{array}{l}\text { Estimated quantity oys- } \\
\text { ters per acre. }\end{array}$} \\
\hline & & & & Spat. & Culls. & Counts. & Seed. & Market. & Total. \\
\hline 664 & Jan. 12,1911 & $\begin{array}{l}\text { Feet. } \\
3.0\end{array}$ & Dense. & 3.3 & 6.7 & 35.0 & $\begin{array}{r}\text { Bush. } \\
70\end{array}$ & $\begin{array}{r}\text { Bush. } \\
560\end{array}$ & $\underset{630}{B \text { Bush. }}$ \\
\hline
\end{tabular}

\section{EAST SIDE OF MARSH ISLAND.}

About 300 yards from the island is a small patch of depleted bottom. Its condition is shown in the following tables:

Oyster Growth on East Side of Marsh Island.

\begin{tabular}{|c|c|c|c|c|c|c|}
\hline \multirow{2}{*}{ Character of oyster growth. } & \multirow{2}{*}{ Area. } & \multicolumn{2}{|c|}{ Oysters per acre. } & \multicolumn{3}{|c|}{ Estimated content of oysters. } \\
\hline & & $\begin{array}{l}\text { Under } 3 \\
\text { inches. }\end{array}$ & $\begin{array}{l}\text { Over } 3 \\
\text { inches. }\end{array}$ & Seed. & Market. & Total. \\
\hline Depleted... & Acres. & $\begin{array}{r}\text { Bushels. } \\
52\end{array}$ & $\begin{array}{r}\text { Bushels. } \\
6\end{array}$ & $\begin{array}{r}\text { Bushels. } \\
104\end{array}$ & $\begin{array}{r}\text { Bushels. } \\
12\end{array}$ & $\begin{array}{r}\text { Bushels. } \\
116\end{array}$ \\
\hline
\end{tabular}

Detalls of Examination of East Side of Marsh Island.

\begin{tabular}{|c|c|c|c|c|c|c|c|c|c|}
\hline \multirow{2}{*}{$\begin{array}{l}\text { Angle } \\
\text { No. }\end{array}$} & \multirow{2}{*}{$\begin{array}{c}\text { Date of } \\
\text { examination. }\end{array}$} & \multirow{2}{*}{$\begin{array}{c}\text { Depth } \\
\text { of } \\
\text { water. }\end{array}$} & \multirow{2}{*}{ Character of growth. } & \multicolumn{3}{|c|}{$\begin{array}{l}\text { Oysters caught per } \\
\text { square yard. }\end{array}$} & \multicolumn{3}{|c|}{$\begin{array}{c}\text { Estimated quantity oys- } \\
\text { ters per acre. }\end{array}$} \\
\hline & & & & Spat. & Culls. & Counts. & Seed. & Market. & Total. \\
\hline 651 & Jan. 11, 1911 & $\begin{array}{l}\text { Feet. } \\
\quad 2.4\end{array}$ & Depleted. . & 0.0 & 7.4 & 0.4 & $\begin{array}{r}\text { Bush. } \\
51.8\end{array}$ & $\begin{array}{r}\text { Bush. } \\
6.4\end{array}$ & $\begin{array}{r}\text { Bush. } \\
58.2\end{array}$ \\
\hline
\end{tabular}




\section{PORTERSILLE BAY, STATE-PLANTED BED.}

This bed is said to have been planted in June, 1910, and it was examined by the survey party on January 11, 1911. The bottom was of a consistency rated in this report from stiff to soft. The oysters were found to be growing in dense clusters and were fit for steaming only. They were evidently planted too thickly and irregularly to secure the best results, and apparently the clusters were not broken up. If they had been separated so as to give the individual oysters room for growth, they would have produced much better and more valuable stock. It is said that the seed oysters, when planted, were about $1 \frac{1}{2}$ inches long. When examined six months later, 40 per cent were between 1 and 3 inches long, 40 per cent between 3 and 4 inches, and 20 per cent over 4 inches.

The experiment indicates that if oysters be planted in this region in accordance with the best practice the results should be excellent. The following tables exhibit the general condition of this bed:

Oyster Growth in Portersville Bay (State-Planted Bed).

\begin{tabular}{|c|c|c|c|c|c|c|}
\hline \multirow{2}{*}{ Character of oyster growth. } & \multirow{2}{*}{ Area. } & \multicolumn{2}{|c|}{ Oysters per acre. } & \multicolumn{3}{|c|}{ Estimated content of oysters. } \\
\hline & & $\begin{array}{l}\text { Under } 3 \\
\text { inches. }\end{array}$ & $\begin{array}{l}\text { Over } 3 \\
\text { inches. }\end{array}$ & Seed. & Market. & Total. \\
\hline Dense.. & $\begin{array}{r}\text { Acres. } \\
8\end{array}$ & $\begin{array}{r}\text { Bushels. } \\
250\end{array}$ & $\begin{array}{r}\text { Bushels. } \\
472\end{array}$ & $\begin{array}{r}\text { Bushels. } \\
2,000\end{array}$ & $\begin{array}{r}\text { Bushels. } \\
3,776\end{array}$ & $\begin{array}{l}\text { Bushels. } \\
5,776\end{array}$ \\
\hline
\end{tabular}

Details of Examination of Portersulle Bay, State-Planted Bed.

\begin{tabular}{|c|c|c|c|c|c|c|c|c|c|}
\hline \multirow{2}{*}{$\begin{array}{l}\text { Angle } \\
\text { No. }\end{array}$} & \multirow{2}{*}{$\begin{array}{c}\text { Date of } \\
\text { examination. }\end{array}$} & \multirow{2}{*}{$\begin{array}{l}\text { Depth } \\
\text { of } \\
\text { water. }\end{array}$} & \multirow{2}{*}{ Character of growth. } & \multicolumn{3}{|c|}{$\begin{array}{l}\text { Oysters caught per } \\
\text { square yard. }\end{array}$} & \multicolumn{3}{|c|}{$\begin{array}{c}\text { Estimated quantity oys- } \\
\text { ters per acre. }\end{array}$} \\
\hline & & & & Spat. & Culls. & Counts. & Seed. & Market. & Total. \\
\hline $\begin{array}{l}625 \\
626\end{array}$ & $\begin{array}{l}\text { Jan. } 11,1911 \\
\ldots . \text { do............. }\end{array}$ & $\begin{array}{r}\text { Feet. } \\
4.3 \\
4.0\end{array}$ & $\begin{array}{l}\text { Dense.... } \\
\text {.....do... }\end{array}$ & $\begin{array}{l}1.0 \\
1.5\end{array}$ & $\begin{array}{l}45.5 \\
25.0\end{array}$ & $\begin{array}{l}25.0 \\
34.0\end{array}$ & $\begin{array}{l}\text { Bush. } \\
315.5 \\
185.5\end{array}$ & $\begin{array}{r}\text { Bush. } \\
400.0 \\
544.0\end{array}$ & $\begin{array}{r}\text { Bush. } \\
715.5 \\
729.5\end{array}$ \\
\hline
\end{tabular}

PORTERSTILle BAY, NORTH END.

This is a small bed of very scattering growth, about 700 yards from the north shore of the bay. It is probable that there may be other insignificant patches in the vicinity. The character of the bed is sufficiently indicated by the following tables:

Oyster Growth in Portersville Bay, North End.

\begin{tabular}{|c|c|c|c|c|c|c|}
\hline \multirow{2}{*}{ Character of oyster growth. } & \multirow{2}{*}{ Area. } & \multicolumn{2}{|c|}{ Oysters per acre. } & \multicolumn{3}{|c|}{ Estimated content of oysters. } \\
\hline & & $\begin{array}{l}\text { Under } 3 \\
\text { inches. }\end{array}$ & $\begin{array}{l}\text { Over } 3 \\
\text { inches. }\end{array}$ & Seed. & Market. & Total. \\
\hline Very scattering... & Acres. & $\begin{array}{r}\text { Bushels. } \\
122\end{array}$ & $\begin{array}{r}\text { Bushels. } \\
57\end{array}$ & $\begin{array}{r}\text { Bushels. } \\
244\end{array}$ & $\begin{array}{r}\text { Bushels. } \\
114\end{array}$ & $\begin{array}{r}\text { Bushels. } \\
358\end{array}$ \\
\hline
\end{tabular}


Details of Examnation of Portersunle Bay, North End.

\begin{tabular}{|c|c|c|c|c|c|c|c|c|c|}
\hline \multirow{2}{*}{$\begin{array}{l}\text { Angle } \\
\text { No. }\end{array}$} & \multirow{2}{*}{$\begin{array}{l}\text { Date of } \\
\text { examination. }\end{array}$} & \multirow{2}{*}{$\begin{array}{l}\text { Depth } \\
\text { of } \\
\text { water. }\end{array}$} & \multirow{2}{*}{ Character of growth. } & \multicolumn{3}{|c|}{$\begin{array}{l}\text { Oysters caught per } \\
\text { square yard. }\end{array}$} & \multicolumn{3}{|c|}{$\begin{array}{l}\text { Estimated quantity oys- } \\
\text { ters per acre. }\end{array}$} \\
\hline & & & & Spat. & Culls. & Counts. & Seed. & Market. & Total. \\
\hline $\begin{array}{l}592 \\
593\end{array}$ & $\begin{array}{l}\text { Jan. } 10,1911 \\
\text {....do.......... }\end{array}$ & $\begin{array}{r}\text { Feet. } \\
6.0 \\
6.0\end{array}$ & $\begin{array}{l}\text { Very scattering. } \\
\text {.................. }\end{array}$ & $\begin{array}{l}2.8 \\
5.7\end{array}$ & $\begin{array}{r}7.0 \\
19.3\end{array}$ & $\begin{array}{l}2.8 \\
4.3\end{array}$ & $\begin{array}{r}\text { Bush. } \\
68.6 \\
175.0\end{array}$ & $\begin{array}{r}\text { Bush. } \\
44.8 \\
68.8\end{array}$ & $\begin{array}{r}\text { Bush. } \\
113.4 \\
243.8\end{array}$ \\
\hline
\end{tabular}

WEST SIDE OF COFFEE ISLAND.

Along a considerable part of the southern half of the west shore of Coffee Island is a fringe of depleted bottom. It is stated that this was at one time moderately productive, but there is but an occasional scattered cluster of oysters to be found at present, and their distribution was so irregular that it was not possible to arrive at an estimate of their quantity. This narrow fringe of bottom is useful for planting but valueless for oyster producing in its natural state.

\section{THE BEDS IN SUMMARY.}

Within the limits of this survey the natural beds are confined to two general regions- (a) Mobile Bay and Mississippi Sound adjacent to their junction and $(b)$ in Portersville Bay and vicinity. It is stated that formerly there were oysters in Grand Bay, where none or practically none exist at present, and recently a bed was reported in the open sound, somewhere south of Grand Bay near the State line. If the latter exist, it can not be of much importance, as a search as careful as the circumstances seemed to warrant failed to reveal it. There are a few scattered clusters of oysters close to shore on the west side of Coffee Island, but they are not worthy of consideration as natural growth.

The contiguous parts of Mobile Bay and Mississippi Sound contain by far the most extensive and productive oyster beds in the State. As is shown on the chart, there extends from Buoy Reef to Pass Drury a practically continuous area of dense and scattering growth flanked, especially toward the sound, by very scattering oysters and depleted bottom. These beds, including Kings Bayou Reef and Heron Bay, cover a total area of 3,900 acres, of which 1,451 acres bear dense, 501 acres scattering, and 436 acres very scattering growth, while 1,512 acres are classed as depleted.

The depth of water over these beds is slight and, excepting the passes and gullies, remarkably uniform, ranging generally between 1 and 4 feet. On Buoy and Kings Bayou Reefs the depth is a few feet greater, as is shown on the chart.

The remaining beds, which are confined to Portersville Bay and vicinity, contain but about 108 acres, part of which appears to lie 
within private claims. In addition to this there are what appear to have been natural beds, lying in less than 2 feet of water, between Cat Island, Murder Point, and the mouth of Goose Bayou, most of which are now planted or claimed as planted.

The entire area of 4,008 acres of natural beds surveyed embraces 37 per cent of dense growth, 13 per cent of scattering, 12 per cent of very scattering, and 38 per cent of depleted bottom. This distribution is summarized in the following table:

Summarized Statement of Areas of Market Oysters on Public Beds.

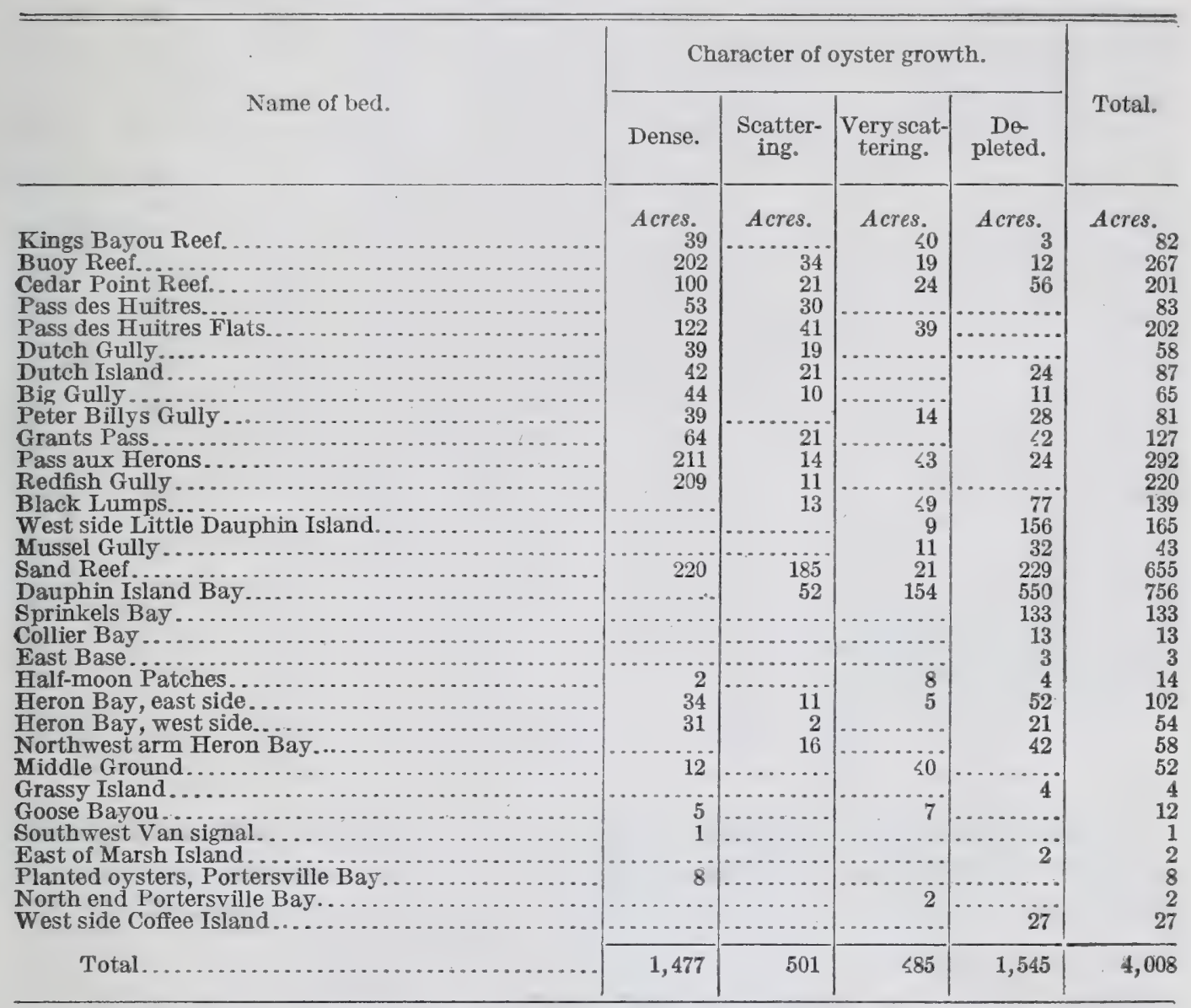

It should be understood that the foregoing classification in respect to relative density of oyster growth is based solely on the quantity of oysters 3 inches or more in length, irrespective of the quantity of small oysters present. The classification furthermore represents the condition at the time of examination and the several classes may, and undoubtedly will, undergo redistribution from time to time. The areas of dense growth may become less productive from overfishing or other causes, while a heavy set of spat may bring the lower classes into increased productivity and raise them a step higher in the scale. In some cases the number of young oysters on the beds at the time of examination was sufficient to produce this effect in the following year. On the whole, however, the general conditions shown in this report, barring accidents, should be main- 
tained for a period of years. The estimated total content of oysters on the several parts of the different beds is shown in the following table:

Summarized Content of Market Oysters on Public Beds.

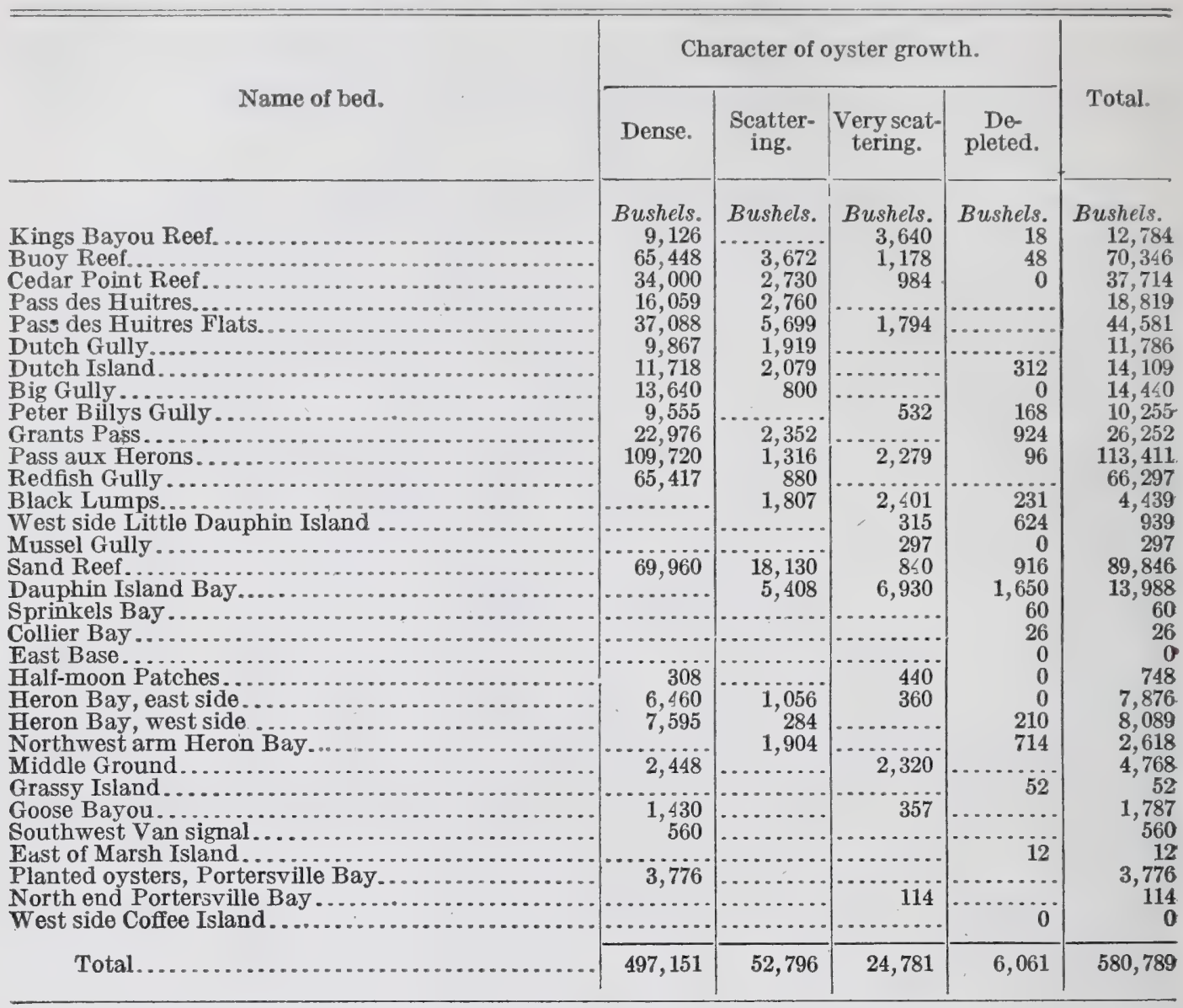

Of the total it is estimated that the beds lying in the contiguous parts of Mobile Bay and Mississippi Sound bear over 98 per cent, or 569,720 bushels, of which 488,937 bushels occur as dense growth, 52,796 bushels as scattering, 21,990 bushels as very scattering, and but 5,997 bushels on the so-called depleted bottom. It will be seen from this that the depleted bottom and even the areas of very scattering growth bore a wholly insignificant crop of oysters at the time of examination. The present negligible character of these two classes, and especially the lowest, regarded as naturally productive beds, is still more plainly seen by a comparison of their content per acre with that of the areas of dense and scattering growth.

Considering as a whole all of the beds examined in the State, aggregating 4,008 acres, the areas classed as dense bore an average of 336 bushels of oysters of market size per acre, the scattering 105 bushels, very scattering 51 bushels, and the depleted but 4 bushels. It should be stated that for the more prolific growths the averages probably understate the truth, while for the very scattering and depleted growths they are approximately accurate. On very rank growth the 
tongs will not always take up all oysters within their grasp, and as the foregoing estimates are based primarily on the area of bottom covered by a "grab" and the number of oysters taken therein, the actual density of growth is somewhat greater than shown. Where the oysters do not lie so thickly this is not true.

On some of the beds, notably Buoy Reef, Grants Pass, Pass aux Herons, and Redfish Gully, oystering had been carried on for a month or two prior to the examination, and the survey therefore disclosed fewer oysters than had been on the beds at the beginning of the season. Moreover, the bushel as measured by the survey party contains probably at least 30 per cent more oysters than the ordinary market bushel, as to secure uniformity in the case of the former the oysters are culled and the clusters broken to singles and doubles and carefully packed in the measure.

Of less immediate importance, but greater potential significance than the marketable oysters, are the young ones. Upon them depends the future of the fishery. A bed with a large number of healthy young, not unduly subject to accident, is an asset of more value than a bed of old oysters whose future is imperiled by a deficiency of spat. That in this respect the principal beds covered by the survey are in good condition is shown by the following table:

Summarized Content of Young Oysters on Public Beds.

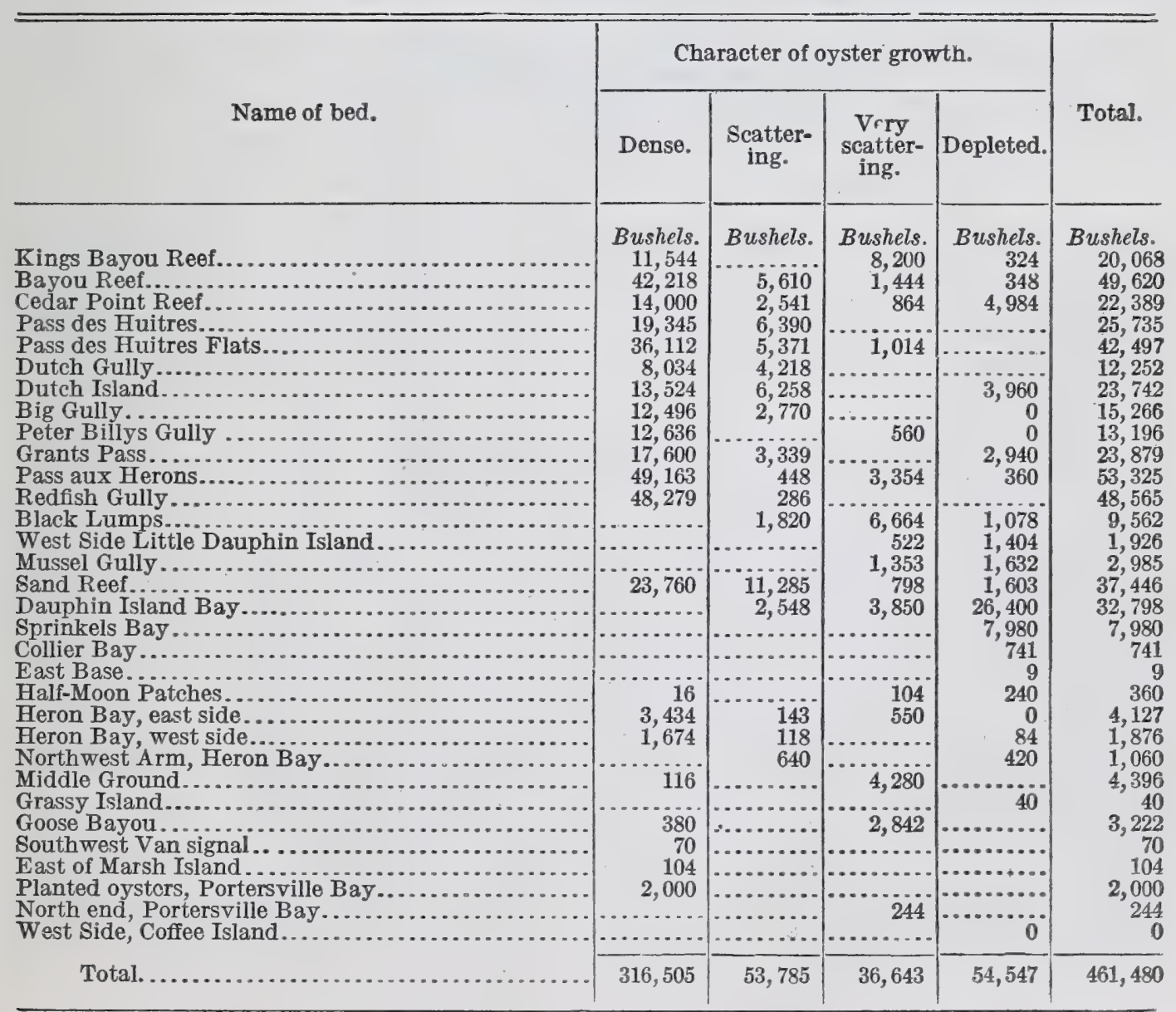


It will be observed by comparing this table with that showing the content of market oysters that certain beds, such as Kings Bayou, Pass des Huitres, Dutch Island, ete., bear a quantity of small oysters in excess of those of marketable size. On other beds, particularly those like Bayou Reef, Pass aux Herons, ete., which have been most worked, the contrary is the case, the small being quantitatively less than the large. The reasons for this diflerence, particularly striking in view of the loss of large oysters which Bayou Reef, Pass aux Herons, and similar beds sustain through the fishery, may differ with the beds concerned. It is probable that $\mathrm{K}$ ings Bayou Reef, from its location, feels the effects of freshets, and many of the oysters are killed before they reach a large size, leaving a preponderance of young. On other beds the oysters are so densely crowded as to leave but little room for growth, or they may be disadvantageously situated with respect to the food supply, and the small oysters are stunted specimens rather than young. This fact is of some importance when the oysters are used as seed, for stunted oysters generally grow less rapidly than normal young when transplanted to places where the growing conditions are more favorable.

In considering the adequacy of the small oysters to maintain the future supply of marketable oysters, the measured quantity is misleading, owing to the difference in bulk of individuals at different ages. The significant real condition is the numerical relationship which is shown in the following table:

Number of Oysters Under 3 Inches Long for Each One Oyer that Length on the Several Beds.

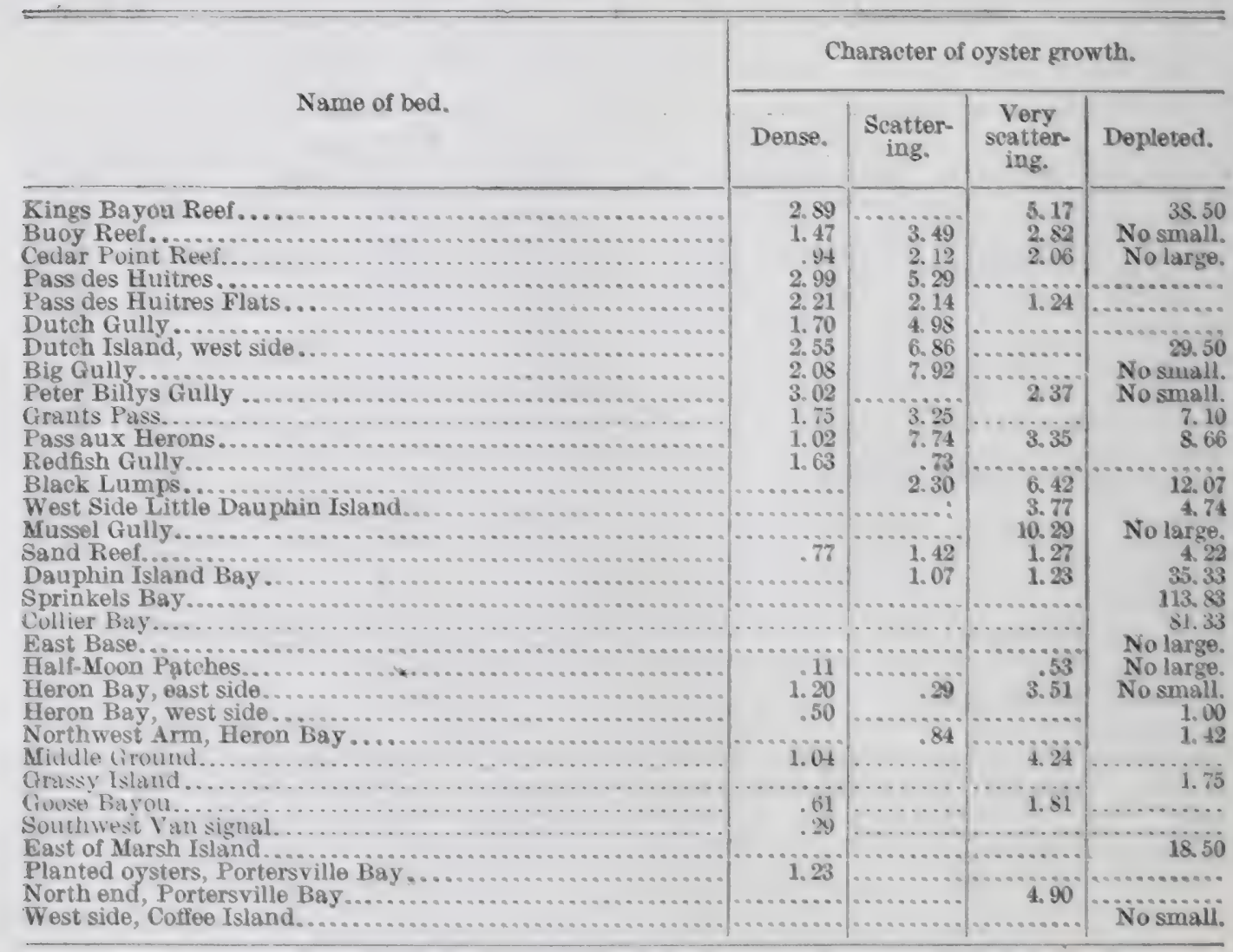


It will be seen from this table that there is a considerable numerical preponderance of small over large oysters practically everywhere, excepting on the dense parts of Buoy, Grants Pass, Pass aux Herons, and Redfish Gully beds, which at present sustain the principal fishery in the region. On all of these the proportion of small to large oysters is less than 2 to 1 , and on Pass aux Herons bed they are in approximately equal numbers.

In a region of rapid growth, such as that under consideration, it may be assumed that most, if not all, of the oysters under 3 inches long in January will measure more than that length in the following winter. Leaving out of consideration the question of mortality, the death rate among the oysters during the year in which they were progressing from the small to the market size, a bed on which during the winter there is one oyster under 3 inches for every one over that length should be in no immediate danger of depletion, provided the culling laws be observed. As a matter of fact, however, some of these oysters will die during the year and the rate of death will depend on the local conditions and the degree to which the beds are exposed to enemies and physical perils. There was disclosed during the survey no evidence of serious mortality from oyster enemies or other cause on the beds in the vicinity of Grants Pass, and it may be with safety assumed that young oysters of the sizes found in January will not suffer a greater average mortality than about 30 to 40 per cent within the year, unless subjected to freshets or other accidents. This estimate would fix the minimum requirement of young oysters to maintain the present productiveness of the beds at $1 \frac{1}{2}$ for each market oyster present, or more accurately, for each one removed from the beds by death or by the fishery.

As all of the market oysters can not be taken, it is apparent that none of the beds, with the possible exception of Pass aux Herons, are in immediate danger of depletion. The author does not think that even the excepted bed is threatened by the present extent of the fishery.

In the year ended June 30,1911 , the tongers took from the public beds of Mobile County about 180,000 market bushels, mostly from Grants Pass, Pass aux Herons, and Redfish Gully. This, it will be observed, is considerably less than the estimated content of these beds in January, when a considerable quantity of their product already had been removed. These beds at that time contained about 200,000 bushels of oysters over 3 inches long, or about 265,000 bushels as they are measured for the market.

Practically the only parts of the beds which can be fished with profit at the present time are those which are classed as dense and $65397^{\circ}-13-4$ 
scattering, aggregating 1,978 acres, with a total estimated marketable content of about 550,000 bushels of oysters. It is believed that these beds would safely sustain, with a proper observance of the culling laws, an annual yield double the present product of dredges and tongs combined, about 275,000 bushels. Many of the beds would be benefited by a reasonable fishery which would remove part of the oysters now going to waste, and allow room for the remainder to grow and improve. In many places a considerable proportion of the small oysters could be removed to advantage, and there would result a double benefit if they were used as seed on some of the barren bottom now going to waste.

\section{BARREN BOTTOMS.}

The area of barren bottoms-that is, those which are not naturally productive of oysters even in small quantities-vastly exceeds that of the natural beds, including in the latter those so-called depleted areas which bear practically nothing. These bottoms are barren mainly because of one character in which they differ from the productive areas, namely, that they are devoid of shells or other objects lying on the surface. They consist of sand or mud of varying degrees of stability and consistency. Oysters, immediately after they develop from the egg, for a brief period swim or float freely in the water, settling to a fixed condition only after they reach a stage of considerable development. ${ }^{a}$

It is not necessary to give more detail to this subject other than to say that at the time at which they are undergoing fixation the oysters are very minute, and a slight film of mud or slime is sufficient to stifle them. During the spawning season these little organisms are present in the water in untold myriads and are precipitated to the bottom in a continuous gentle drizzle of tiny specks. If they fall on an oyster bed they find firm supports on the shells and oysters, attach themselves and grow, but if they fall on the mud or bare sand they die.

The natural beds have been slowly developed on bottom similar to that which surrounds them solely because through some agency there originally lodged on the mud or sand some hard objects to which the young oysters could safely cling. Oysters developing there, and their shells scattered about by the waves, furnished additional places for fixation of new generations of young, with the result that the original growth extended in area and its base became a compact mass of shells and fragments, beneath which can still be found by excavation or probing the original bottom differing in no essential particular from the adjacent barren areas.

a For a more extended account, see "Oysters and Methods of Oyster Culture," by H. F. Moore, Bureau of Fisheries, Document 349, which may be obtained by application to the Bureau of Fisheries, Washington, D.C. 
All that is required by the barren bottom in order that it may become productive is that its surface should be supplied with hard objects or culteh, either through natural agencies or by the hand of man. The capacity of the bottom to sustain material deposited on it and to maintain it in proper condition to serve as cultch depends largely on its stability and consistency. Moving sands gradually cover objects deposited on their surface and soft mud permits them to sink. It is therefore of prime importance for the oyster culturist to have information concerning the character of the bottom and it was one of the purposes of the survey to supply it.

The methods and the instrument employed have been described in the introductory part of this report and the results attained are shown graphically on the chart. No data concerning the bottom are supplied for that part of Mobile Bay covered by the survey, for the reason that the salinity of the water in that region is subject to such violent reduction by freshets as to interfere with successful oyster culture. The chart does not show all of the places at which the bottom was tested, enough stations only being shown to indicate the characteristics. It will be observed that the bottom in most of the deeper part of the sound is composed of either very soft mud or ooze and is entirely unsuitable for oyster planting. Furthermore, the hard bottom occurring close to the islands which form the south shore is composed principally of sand, which shifts during storms. There is a strip along the boundary between the mud and sand where the two materials are blended in such proportions as to give a fair degree of stability, but the zone is narrow, and in general it may be stated that to plant either in the very soft bottom of the deeper water or the sand of most of the south shore, excepting its extreme eastern end, is to invite disaster.

With these two general regions eliminated there remains practically the north shore alone, of which the areas of bottom sufficiently firm to support oysters and shells are discussed in the following pages. The total area of the tracts containing bottoms suitable for oyster culture in that part of Mississippi Sound within the State is 24,420 acres. It must be understood, however, that within the regions hereafter described there are usually areas of unsuitable bottom irregularly distributed.

\section{NEAR HALF-MOON PATCHES.}

This area lies west of the Pass des Huitres beds and south of HalfMoon Patches, covering an area of approximately 400 acres. The bottom consists principally of hard mud in its eastern half, gradually becoming softer toward the west. In places a soft surface 6 to 8 inches deep is underlaid by hard or stiff mud and there are occasional small patches of scattered shells either at the surface or buried. Toward the northern part of the area there are a few clustered oysters. 
HERON BAY.

Between the two natural beds lying on the opposite sides of this bay is an area of about 70 acres of muddy bottom ranging from moderately stiff to soft, a considerable part of which could be used for oyster culture. In places the mud holds buried shells.

\section{PORTERSVILLE BAY (INCLUdiNG FOWL RIVER BAY).}

In general, the whole of this bay, with the exception of its northwest quarter, has a bottom sufficiently firm for oyster planting, and even in the excepted area there is good bottom close to the shores. In Fowl River Bay the mud ranges from moderately soft to stiff, but in the southern half of Portersville Bay proper the bottom consists of hard and stiff mud and small patches of sand. In many places the bottom is stratified, a very compact layer underlying from 4 to 8 or 10 inches of less hard material. Between Cat Island and Murder Point there are considerable quantities of oysters, indicated on the chart as private beds. It is estimated that about 5,250 acres of good planting bottom lie within the limits of Portersville and Fowl River Bays, including that held under riparian rights.

SOUTH OF PORTERSVILLE BAY.

From Marsh and Cat Islands a sand spit extends southward for a distance of about 3 miles. In the shoaler part of this toward the islands the bottom is shifting, but about a mile off shore in a depth of from 5 to 9 feet of water there is sufficient mud blended with the sand to give it stability. This area, lying just north of the middle of the sound opposite Marsh Island, covers approximately 1,700 acres.

\section{WEST AND SOUTHWEST OF COFFEE ISLAND.}

In this region there is a triangular area with Coffee Island as its base and its apex about $1 \frac{1}{2}$ miles to the westward, in which a considerable part of the bottom lies west and southwest of the southern part of the island, where it is composed of mud or a mixture of mud and sand close to shore, while within the limits of riparian control the bottom is generally hard or stiff. The total area included within his triangle is about 2,900 acres.

\section{NORTH END OF COFFEE ISLAND.}

This is a nearly semicircular area lying between the mainland and a line running from near the hotel on the north shore of Portersville Bay to a point about 1 mile west of the north end of Coffee Island, and thence to the mouth of Bayou la Battre. In a channel encircling the northern end of the island the bottom is soft, but in most other places it is fairly firm or, near the shores, hard. Most of the good 
bottom is within the rights of riparian owners. The total area is about 1,110 acres.

There is some good bottom near the shore in Ile aux Dames Bay, but the middle of the bay is soft.

\section{GRAND BAY.}

Practically all of Grand Bay, with the exception of a semicircular area near its mouth, has a hard or moderately hard bottom, which could be utilized with safety for purposes of oyster culture. Near the mouth there is some very soft bottom and the sand bars between which the deep channel passes are composed of unstable material shifting under the influence of the waves. The area of good bottom in the bay is about 5,000 acres.

\section{SOUTH OF GRAND BAY.}

Within the boundary formed by a line beginning about one-half mile off Point aux Pins and running south for about 5 miles, thence westerly toward Grand signal, to the State line, thence northward to within about one-half mile of Dunn signal, thence parallel with the shore of Grand Batture for about $2 \frac{1}{2}$ miles, and thence to the point of beginning is an area of bottom ranging in general consistence from hard to soft. A considerable part of this is, in its natural state, sufficiently firm to support oysters and shells, and much of the remainder could be rendered suitable at comparatively small expense. This is the largest continuous area of like nature within the limits of the survey, containing 8,000 acres. In places it appears to offer supreme advantages for the growth of market oysters from seed, as it will probably be found that the drill will kill off any undesirable set of spat without attacking the seed.

\section{GENERAL PHYSICAL AND BIOLOGICAL CONDITIONS.}

TIDES AND CURRENTS.

Staff tide gauges were established at Grants Pass and at the cannery wharf at Coden. The former was maintained from November 18, 1910, to January 19, 1911, and the latter from January 6 to January 29,1911 . The former was referred to the bench mark established on Grants Island by the United States Engineer's Office, which is. described as follows:

The bench mark is the top of a 2-inch pipe which was driven in the ground, a fence placed around it and filled with concrete to within one-half inch of the top of the pipe. The letters U.S.B.M. were written in the concrete before it set. The bench mark is at the northwest side of and near the keeper's house on Grants Island. It has an elevation of 2.654 feet above mean low tide in Mobile Bay as determined by this office. (J. M. Pratt, Assistant Engineer, United States Engineer's Office, Mobile, Ala., Dec. 10, 1910.) 
The top of the bench mark accorded with reading 3.65 on the scale of the staff gauge.

The tides in this region, as in general on the Gulf coast, are small, averaging from 1 to $1 \frac{1}{2}$ feet in height, but reaching $2 \frac{1}{2}$ feet under certain conditions of wind, etc.

No special observations were made of the velocity of the currents, but in general they are sufficient for the transport of food and water to the oysters in all places covered by the survey.

\section{SALINITY OF THE WATER.}

As is well known, the quantity of salt in the water is an important factor in determining the growth and character of oysters. Neither fresh water nor that of full oceanic saltness is suitable for the oyster itself, and, moreover, the degree of saltness often determines the presence, absence, or relative abundance of such oyster enemies as the drill or borer. During the survey upward of 300 specific-gravity observations were made to determine the condition of the water in respect to its content of salt. Three tests were made daily on the Fish Hawk, and in addition observations were taken on the oyster beds and in their immediate vicinity. The following table is a summary of all of the ship's observations, supplemented by some of those taken on and near the important natural beds:

Specific Gravity of Water at Various Places and Dates.

\begin{tabular}{|c|c|c|c|c|c|}
\hline Locality. & Date. & $\begin{array}{c}\text { Average } \\
\text { temper- } \\
\text { ature. }\end{array}$ & $\begin{array}{l}\text { Average } \\
\text { specific } \\
\text { gravity. }\end{array}$ & $\begin{array}{l}\text { Maximum } \\
\text { specific } \\
\text { gravity. }\end{array}$ & $\begin{array}{l}\text { Minimum } \\
\text { specific } \\
\text { gravity. }\end{array}$ \\
\hline \multirow{5}{*}{ 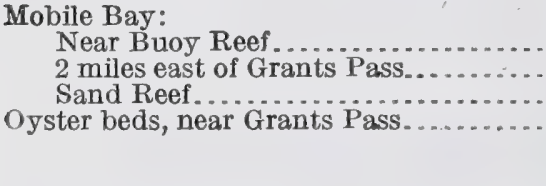 } & \multirow{6}{*}{ 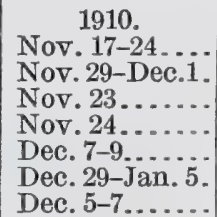 } & \multirow{2}{*}{${ }^{\circ} F{ }_{60}$} & & \multirow{4}{*}{$\begin{array}{l}1.0206 \\
1.0215 \\
1.0191\end{array}$} & \multirow{4}{*}{$\begin{array}{l}1.0122 \\
\text { 1. } 0201 \\
\text { 1. } 0165\end{array}$} \\
\hline & & & & & \\
\hline & & / 56 & $\begin{array}{l}\text { 1. } 0206 \\
1.0178\end{array}$ & & \\
\hline & & & 1. 0193 & & \\
\hline & & $\begin{array}{l}48 \\
50\end{array}$ & $\begin{array}{l}1.0186 \\
1.0150\end{array}$ & $\begin{array}{l}1.0210 \\
1.0200\end{array}$ & $\begin{array}{l}\text { 1. } 0156 \\
\text { 1. } 0114\end{array}$ \\
\hline $\begin{array}{l}\text { Mississippi Sound, } 1 \text { to } 2 \text { miles off Mid } \\
\text { Signal. }\end{array}$ & & 51 & 1. 0235 & 1. 0247 & 1. 0223 \\
\hline & Dec. 12-16. & 54 & 1. 0209 & 1.0235 & 1. 0173 \\
\hline & Dec. $20-22 \ldots . .$. & 51 & 1. 0213 & 1. 0220 & 1. 0206 \\
\hline & Mar. $20-24 \ldots . .$. & 66 & 1. 0198 & 1.0216 & 1. 0160 \\
\hline Portersville Bay. & Jan. 1911. & 54 & 1.0137 & 1.0167 & 1. 0108 \\
\hline Mississippi Sound, one-half milo west of & $\begin{array}{r}1910 . \\
\text { Dec. } 9-11 .\end{array}$ & 54 & 1. 0228 & 1. 0240 & 1. 0223 \\
\hline & Dec. $17-20$. & 55 & 1. 0219 & 1. 0236 & 1. 0211 \\
\hline & $\begin{array}{l}\text { Dec. } 22-24 . \\
\text { Dec. } 27-28 .\end{array}$ & $\begin{array}{l}50 \\
56\end{array}$ & $\begin{array}{l}\text { 1. } 0205 \\
\text { 1. } 0205\end{array}$ & $\begin{array}{l}\text { 1. } 0210 \\
\text { 1. } 0213\end{array}$ & $\begin{array}{l}\text { 1. } 0196 \\
\text { 1. } 0203\end{array}$ \\
\hline & & & & & \\
\hline & Jan. $3-9 .$. & 49 & 1. 0207 & 1.0227 & 1. 0180 \\
\hline & Jan. $10-16$ & 59 & 1. 0180 & 1. 0214 & 1. 0150 \\
\hline & Mar. 14-1 & 64 & 1. 0205 & 1. 0222 & 1. 0174 \\
\hline & Mar. 25-2 & 63 & 1. 0198 & 1. 0216 & 1. 0160 \\
\hline & $\begin{array}{l}\text { Mar. } 2 \\
\text { Apr. } 6\end{array}$ & $\begin{array}{l}65 \\
74\end{array}$ & $\begin{array}{l}1.0197 \\
1.0170\end{array}$ & $\begin{array}{l}1.0206 \\
1.0203\end{array}$ & $\begin{array}{l}1.0188 \\
1.0148\end{array}$ \\
\hline Mississippi Bay, $2 \frac{1}{2}$ miles south of Grand & Jan. $17-20 \ldots .$. & 61 & 1.0178 & 1.0194 & 1. 0154 \\
\hline & Jan. 24-28. & 62 & 1. 0175 & 1. 0206 & 1. 0141 \\
\hline
\end{tabular}


It will be observed that the readings in Mississippi Sound, including those on the beds near Grants Pass, cover the period from November 24, 1910, to April 9, 1911, with an intermission from January 17 to March 13. During this period the average specific gravity varied with time and place between 1.0150 and 1.0235 as compared with fresh water as 1.0000 and full ocean water between about 1.0250 and 1.0260. The lowest specific gravity observed during this period was 1.0114 near Pass des Huitres on January 25 and the highest was 1.0247 off Mid Signal early in December.

The maximum specific gravities are probably as high as usually occur in this region, but in times of freshet in neighboring streams the water undoubtedly becomes much fresher than was observed during the survey. In February and March, 1894, when the previous reconnoissance was made, the water at the bottom of the east end of Grants Pass was 1.0028, at the north end of Portersville Bay 1.0036, about 1 mile southeast of Point aux Herbs 1.0063, and in the mouth of Heron Bay 1.0000 or absolutely fresh, in all cases being much lower in salinity than at the corresponding season of 1911.

These low salinities are all of them below that which is desirable for the production of the best oysters, and the lowest, if it long prevailed, would prove fatal. It is apparent, however, that these conditions are but occasional and that normally they do little or no harm. It is probable even that they are beneficial in periodically reducing the saltness of the water below that which can be tolerated by the drill or borer and by that means keeping that destructive enemy from becoming so numerous as to menace the beds.

\section{OYSTER FOOD.}

In reports on previous surveys a feature usually has been made of the subject of the quantity of oyster food carried by the waters. These discussions have been confined practically to diatoms, minute microscopic plants, which authors generally have been prone to regard as supplying practically all of the oyster's nutriment. Volumetric studies of the microorganism content of the water begun in connection with the survey of Matagorda Bay ${ }^{a}$ in 1905 revealed a quantity so small as to excite the author's suspicion that the living matter was of less relative importance than had been generally supposed.

It appeared possible, however, that the quantity of water filtered by the oyster might be greater than generally supposed and digestion more rapid, and that despite appearances the small quantity of microscopic living organisms in the water and present in the stomach at any one time might be sufficient to furnish material for the growth and general physiological activities of a sluggish animal like the oyster.

a Survey of Oyster Bottoms in Matagorda Bay, Tex. By H. F. Moore. Bureau of Fisheries Document No. 610 . 
To test the matter, apparatus and methods ${ }^{a}$ were devised for the volumetric determination of the organisms actually eaten during comparable periods of time. The result of this work, which has been carried on at intervals for several years by the author and Mr. T. E. B. Pope, has shown that while the quantity of water filtered is great, averaging, roughly, about 30 quarts daily for oysters $4 \frac{1}{2}$ inches long, the volume of the living food is insufficient to account for the actual growth of the oyster, making no allowance for the requirements of the other vital activities. It appears that finely divided organic débris or detritus, which constitutes the major part of the material ingested, plays a more important rôlc in the oyster diet than has been conceded, a view which recently has been advanced by Petersen and Jensen. ${ }^{b}$

In view of these facts and probabilities, and the present impossibility of establishing a standard for the expression of the quantity of food available, the data respecting the food content of the water collected during this survey will not be stated here. A special paper on the entire subject of the food and feeding of oysters will be issued on the completion of the studies.

It may be stated from observation of the oysters and on general grounds that the food supply in Mississippi Sound and minor contiguous waters is ample.

\section{OYSTER ENEMIES.}

The survey, since it was carried on during the colder season of the year, was not favorably timed for the study of the enemies of the oyster in this region. The only ones observed were a few drills and mussels, but the drumfish also is known to occur.

Drill, borer, snail, whelk, conch; etc. (Purpura hæmostoma).-A comparatively small number of the animals variously known by these several names was found on the natural oyster beds, particularly those in the vicinity of Little Dauphin Island from Pass aux Herons southward. This is the region nearer the mouth of Mobile Bay, and therefore the more accessible to the influx of salt water from the open Gulf.

On some of these beds the drills were found at their work of destruction but in other places their presence at times was to be inferred only by the mortality, especially among the spat and young oysters, which are more susceptible than adult oysters to their attacks.

It can not be stated that these enemies were particularly destructive at the time of the survey, but it is reported that many oysters have been destroyed by them at intervals in the past, and, as might be

$a$ Volumetric studies of the food and feeding of oysters. By H. F Moore. (Proceedings of the Fourth International Fishery Congross, Washington, 1908.) Bulletin Bureau of Fisheries, vol. XxvII, 1908, p. 1295-1308.

$b$ Valuation of the Sea. I.-Animal life of the sea bottom, its food and quantity. By C. G. Joh. Petersen and P. Boysen Jensen. Report of the Danish Biological Station, xx. Copenhagen, 1911. 
expected, their inroads appear to have been coincident with periods of prevalence of highly salt water on the beds.

The drill or whelk lays its eggs in red or purple leathery capsules about one-half inch long and attached in clusters to shells, snags, and other firm bodies in the water. The young become destructive to the minute spat immediately on emerging from the egg cases, they grow rapidly, and progress in destructiveness as they increase in size. They destroy the oysters by drilling a small round hole through the shell, using for the purpose a flexible rasp-like organ lying at the end of a protrusible proboscis. After the shell is perforated the proboscis is thrust into the shell and the contents eaten, other drills sometimes partaking of the feast by entering the gaping shell of the dead or dying oyster. Most of the oysters destroyed are under 2 inches long.

Mussels. - The common black sea mussel is a passive enemy of oysters through its tendency to attach to them and under favorable conditions to grow so rapidly and in such numbers as to cover them completely and stifle them. Also, as its food is the same as that of the oyster, its abundance reduces the supply and in that way deprives the oyster of the nutriment required to make it fat and marketable. Even when neither of these effects are important, mussels injure the fishery, owing to the tenacity with which they are anchored to the oyster, this increasing the labor of culling and making the oyster so unsightly from the adhering fibers of the byssus as to considerably reduce its market value if sold as shell stock. The conditions which make for the abundance of the mussel are not thoroughly understood, but on the Gulf coast it appears to be controlled largely by the relative freshness of the water, the mussels generally flourishing where the salinity is low for prolonged periods. Comparatively few were found in the region surveyed and it is probable that they never or rarely become troublesome on account of the high salinity frequently occurring.

Drumfish (Pogonias cromis).-This, the "black drum," was not observed during the survey, but it is a destructive enemy of the oyster in other parts of the Gulf coast and is reported to destroy oysters on the beds of Alabama. It is migatory, making sudden forays and leaving, with destruction in its wake, often before its presence has been noticed. It destroys the oysters by crushing them between the stout grinding teeth or bones with which its mouth is furnished, and it is peculiarly destructive to the better grade of planted beds, on which the oysters have been culled and separated to permit them to grow and improve in shape and quality. It is especially likely to attack the culled oysters within a few weeks of the time when they are planted, but they are not immune at any time. In Louisiana the drumfish is so destructive in places that the oystermen find it necessary to exclude them by surrounding their bedding grounds with wire fences. 
Oysters in the natural beds, especially when they are much clustered and of the sharp-edged raccoon type, are rarely injured seriously, as the sharp edges of the sholls, presented in all directions, lacerate the lips and mouths of the fish and deter them from extensive destruction. Occasionally the small oysters cullod off by the oystermen are damaged.

The drumfish occurs in waters of all degrees of salinity, from fresh or practically frosh to full oceanic density.

\section{SPAWNING.}

The survey was conducted at the season when the reproductive functions of oysters are in abeyance, and thercforc no definite statement of the spawning season in Alabama can be made. Various investigations carried on by the Bureau st the western end of Mississippi Sound, where the general conditions affecting spawning are essentially the same as at the eastern end, make it possible to indicate with some precision the period during which the sp£wn is likely to be emitted.

It is probable that the eggs may ripen even in the winter, during sustained warm periods, bu' it is doubtful if in these cases, even though the eggs be fertilized, development ever proceeds far enough to secure a set of spat. The normal spawning probably occurs from April to October, as it does in similar waters in Louisiana, and lean shells or other cultch planted during those months should receive a good set of spat. The young oysters are free-swimming organisms during a short period of their early life, and as thcy arc produced in untold myriads on the crowded natural beds and carried considerable distances by the currents, the wator over a large part of the sound must be teeming with the fry during the favorable part of the year. Most of these embryo oysters perish through falling on unsuitable bottom at the beginning of the shell formation, when they are still barely visible to the unaided eye and may be stifled by an exceedingly thin deposit of mud or slime. Those fortunate enough to alight on shells or other oysters, and similar firm supports, survive in large numbers, as is witnessed by the crowded condition of the beds, but over the vastly greater proportion of the bottom there is nothing to afford a haven. The only fundamental difference between an oyster bed and the surrounding barren bottom is that the former presents places for the attachment of the spat and the latter does not.

Many free-swimming oyster fry die as the result of sudden drops in the temperature, though this is not common on the Gulf coast; and many are killed by heavy rainfalls. The latter also tend to retard or suspend spawning through lowering the salinity of the water, and it frequently happens that heavy freshets defer spawning until summer. As freshets usually leave the shells and other cultch in excellent con- 
dition so far as cleanliness is concerned, probably through the destruction of slime-producing organisms, it frequently happens that a late spawning season produces an enormous set.

\section{OYSTER CULTURE.}

In the United States oyster culture is carried on by two methods, the planting of seed or young oysters and the deposit of shells and similar materials on the bottom for the purpose of securing the fixation of spat. The first of these is that which is generally, if not exclusively, employed in Mobile County, Ala., and it is probable that in the immediatc future it will continue to be the dominant practice in that region.

The large number of small oysters in certain of the natural beds, as described in the foregoing pages, renders it advisable that some of them be removed to permit the proper growth and fattening of the remainder. These superfluous young can be utilized to best advantage if planted on suitable barren or depleted bottom. For ordinary cannery purposes mercly the roughest culling of this seed is required, but if it be desired to produce oysters for consumption on the shell or for shipping raw shucked, the large clusters should be broken up. By this means only can they be grown to goodly shape, for if crowded they must accommodate themselves to the space available and will develop into irregular and inferior stock. It is usually not necessary to break the clusters into single oysters, and it is often inadvisable to do so, especially in localities in which the drumfish is likely to occur in numbers. As has already been explained this fish is particularly destructive to culled oysters. The method of planting shells, etc., to promote the attachment of young oysters is highly productive in many localities on the coast of the United States, and in the case of a large development of the oyster industry in Alabama is that in which chief reliance must be placed. The system first described saves oysters which have already set and gives them an opportunity to survive and improve, but shell or cultch planting increases the set by preventing the loss of the fry falling on muddy and other unsuitable bottoms.

It is not necessary to give here an account of the methods of oyster culture, as the subject is discussed in a special pamphlet ${ }^{a}$ which may be obtained, on request, of the Bureau of Fisheries.

Within the limits of the survey oyster culture is at present carried on principally along the north shore of Mississippi Sound, although it is understood that there are a few small planted beds in Dauphin Island Bay and vicinity. The north shore beds are located in Heron, Portersville, Fowl River, and Isle aux Dames Bays. No oysters

a Oysters and methods of oyster culture. By H. F. Moore. Bureau of Fisheries Document No. 349. Extract from Manual of Fish Culture, p. 263-340, pl. I-XVII, 1900. 
from Heron Bay were examined, but some of excellent quality were seen in the last three localities mentioned. The State bed in Portersville Bay was planted too dense and the quality of its product was correspondingly inferior.

The private beds at the time of the survey were apparently all or practically all held under rights attaching to the ownership of the adjacent shores, this until recently being the only manner in which oyster culture could be legally conducted.

It is now possible, however, to procure from the State the lease of barren bottoms beyond riparian control, and this should result in a material increase in the extent of oyster planting and in the prosperity and development of the entire oyster industry of the State.

As is shown in the chart and explained in the section relating to barren bottoms, there are considerable areas of suitable bottom remote from the shores, and in some cases lying well out in the sound in a depth of water permitting the use of methods warranting operations on a large scale. The possible drawback to some of these offshore locations is the occasional high salinity of the water, which may permit the drill to flourish at times and prove destructive, but on the other hand it might operate to prevent an undue development of young oysters on seed too large for the drill to injure. On the other hand, they are less subject than the inshore waters to damage by freshets. For operations on a smaller scale, in which ease of guarding against theft and facility in tonging are considerations, the shallower waters off Portersville and Grand Bay offer advantages.

\section{RÉSUMÉ, CONCLUSIONS, AND RECOMMENDATIONS.}

The following epitomizes the facts developed by the survey, the deductions made therefrom, and recommendations based on them and a consideration of the general conditions obtaining in Mobile County:

1. The survey embraced Mississippi Sound in Alabama and the adjacent part of Mobile Bay, including both the natural oyster beds and the barren bottoms.

2. It was found that the natural oyster beds within this region embraced 4,008 acres, nearly all being near the junction of Mobile Bay and Mississippi Sound. Of this area practically one-half bore oysters in sufficient quantity to warrant tonging and, to a less extent, dredging. On the remainder the oysters are too scattered to be commercially available; but between 500 and 1,000 acres are likely to become productive eventually should there be several years of heavy strike. Probably 1,000 acres are not likely to become productive under natural conditions for many years.

3. It is conservatively estimated that in January, 1911, these beds contained approximately 600,000 bushels of oysters over 3 inches long 
and about 460,000 bushels of smaller ones. As the oysters are meusured in the fishery, these estimates would be increased to about 800,000 and 600,000 bushels, respectively. As an active fishery had been conducted for some time prior to January, the content of the beds at the beginning of the season was considerably greater.

4. Although the quantity of small oysters on these beds is less than of oysters of marketable size, they are numerically in excess. On the areas indicated as bearing a dense growth there are two small oysters and on the scattering growth four small oysters to each one over 3 inches long. As an average of one year would be sufficient to promote most of the young to the marketable class, it is apparent that in the absence of disaster due to freshets or oyster enemies it would be safe to take from these beds at least about 600,000 bushels, as measured by oystermen, without fear of depletion. This is over twice the quantity taken in Mobile County during 1911. Some of the beds do not at present produce oysters of good quality; but these would doubtless improve under a judicious removal of $\rho$ art of their contents either for canning or, preferably, for transplanting either on depleted natural beds or on private grounds.

5. While the increased take from the natural beds indicated in the preceding paragraph as safely allowable would permit a valuable expansion in the oyster industry of the State, it without doubt will not suffice for the supply of the ultimate demand, and eventually it will be necessary to greatly increase the area of the oyster-producing bottom. The demand will have two sources-the canneries and the shell-stock and raw-shucking trade. While the former can be satisfied by the class of oyster produced by the natural reefs, the latter to a large extent demands a better grade. The demand, therefore, will be for not only an increase in quantity, but an improvement in quality.

6. The conditions stated at the close of the preceding paragraph can not be fully satisfied excepting by a resort to oyster culture under private ownership, with its consequent demand of personal interest and attention. Until recently the laws of Alabama have restricted the rights to engage in oyster culture to riparian owners and their lessees, but the present law permits the lease of any barren bottoms belonging to the State. According to the survey, these are in Mississippi Sound and its contiguous bodies within the limits of Alabama, approximately 25,000 acres of barren bottom suitable for oyster planting or which can be made suitable at small expense. Part of this is in open waters with considerable depth and part in sheltered shallow places, thus affording advantages for operation on both large and s'nall scales.

7. In common with other places on the Gulf coast, these waters offer to the oyster planter a field less exposed to the storms and 
rigors of winter and therefore less subject to interruption than in the North, but on the other hand with a shorter season owing to the late fall and early spring. They have the further advantage that a yearly set of spat is assured and the growth much more rapid than in other waters. The enemies to contend with are no worse than in many places in the North, but in the inshore waters there is possibly more frequent damage from freshets.

8. The sparse population on the shores near the oyster bottoms renders the oysters little subject to injurious pollution from drainage and sewage discharges. This consideration is an important asset at a time when the spread of infection through oysters is a matter of such widespread public concern, and for business reasons, if for no others, the cleanliness of the beds and the treatment of the oysters should be jealously safeguarded. For this reason the process of floating, freshening, or "fattening" the oysters should be rigorously supervised and absolutely prohibited if streams or other waters receiving a sewage discharge or similar contamination are utilized for the purpose. Not only the State oyster commission and boards of health but the oystermen themselves should see that nothing is done to jeopardize public health. Aside from the moral aspect of the matter the future of the oyster industry depends largely on a maintenance of the reputation of its product for cleanliness and wholesomeness.

9. One of the most valuable and certainly the most enduringly valuable results of the survey is the establishment of permanently marked and accurately determined triangulation points by the United States Coast and Geodetic Survey, supplemented by a few established by the Bureau of Fisheries. In all future surveys of leased bottoms, these should be utilized and the corners of the leaseholds determined by reference to them. A strict and consistent compliance with this recommendation will prevent disputes and litigation should oyster planting become as important as it has in other places and it will insure accuracy in the surveys, guaranteeing an honest return to the State from the rental of its barren bottoms. 


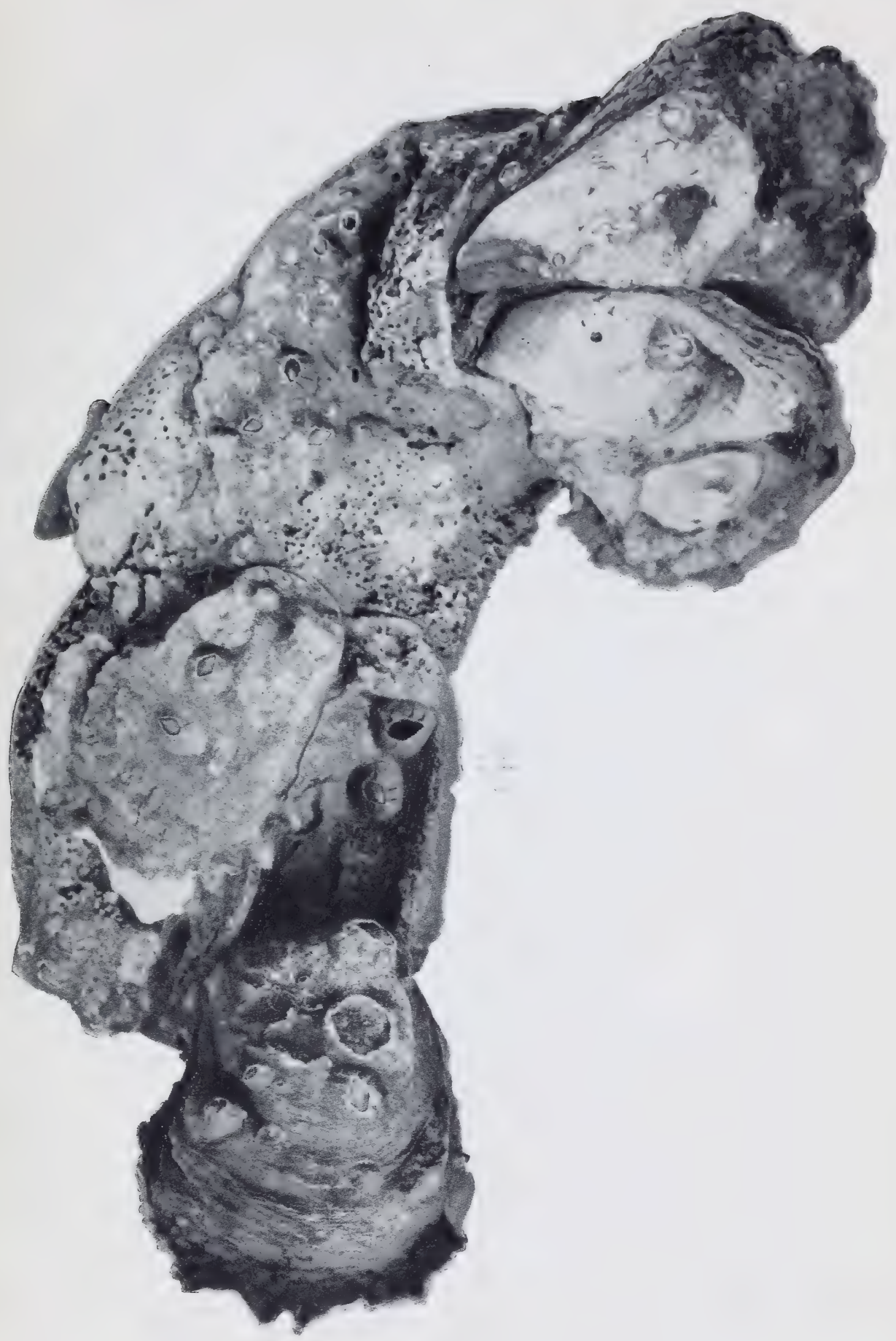

OYSTER CLUSTER FROM GRANTS PASS. 


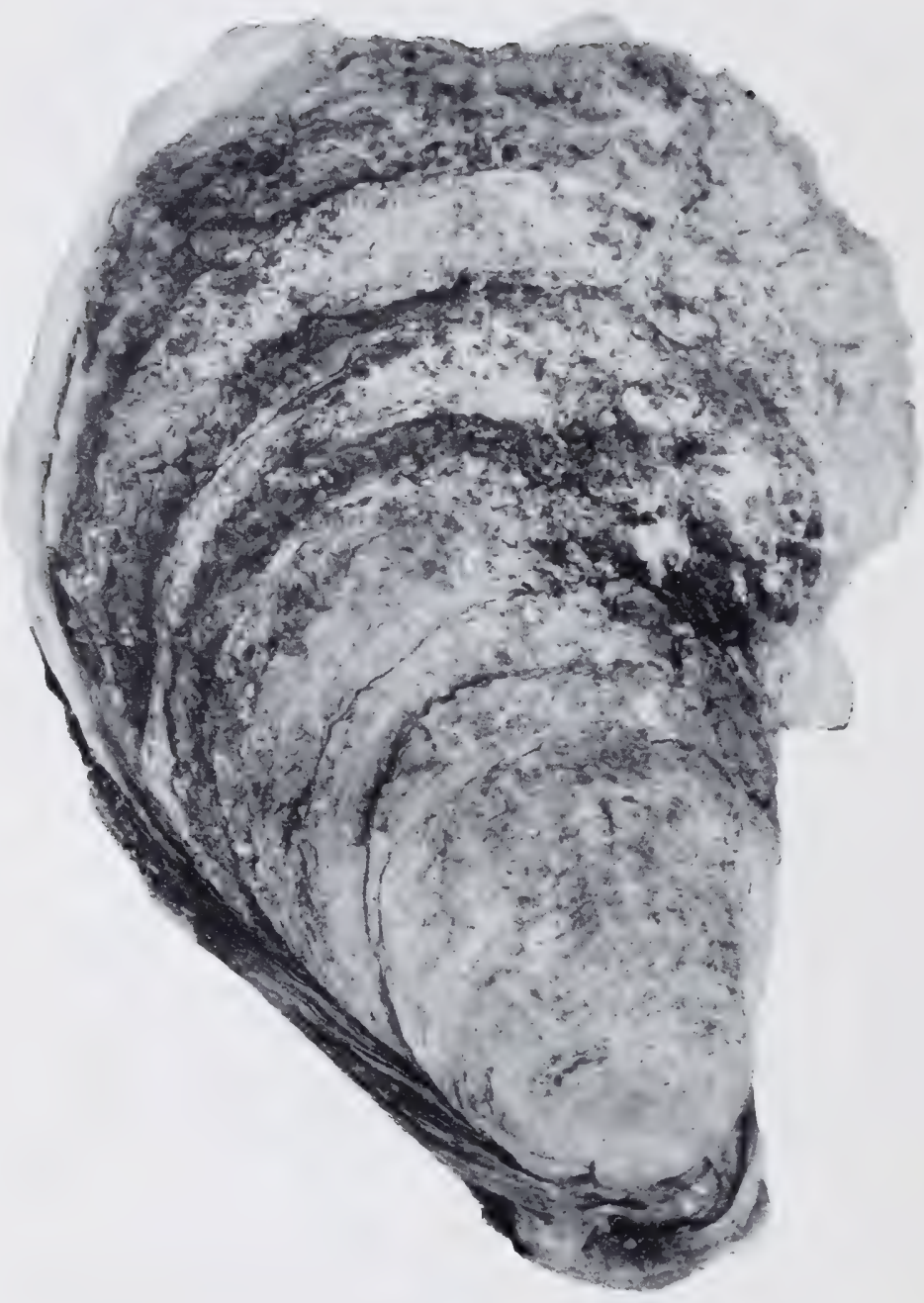

SINGLE OYSTER FROM GRANTS PASS. 


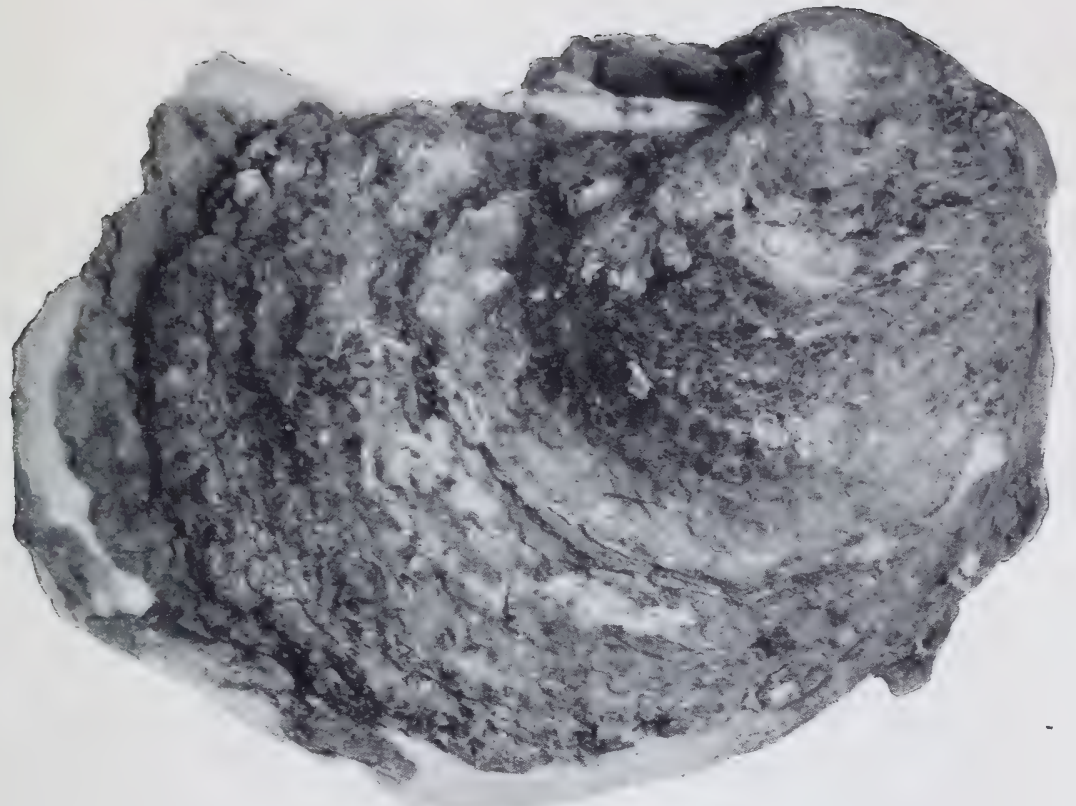

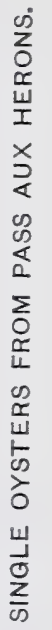

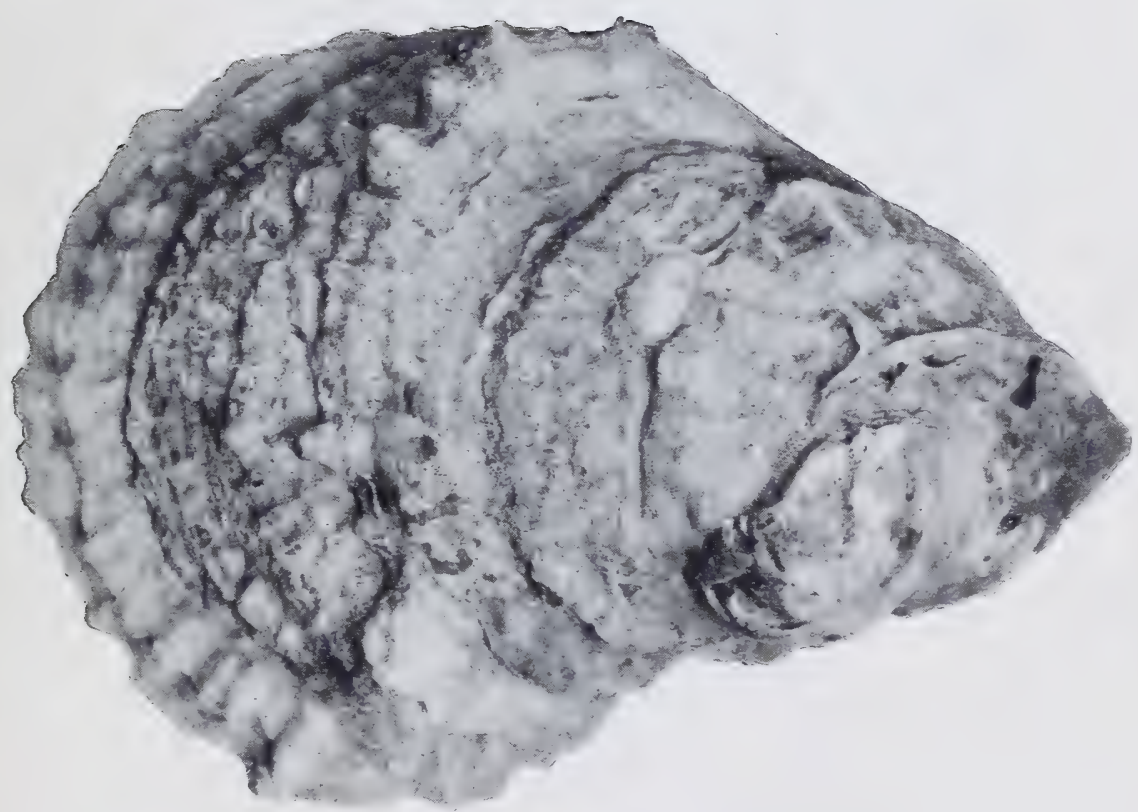




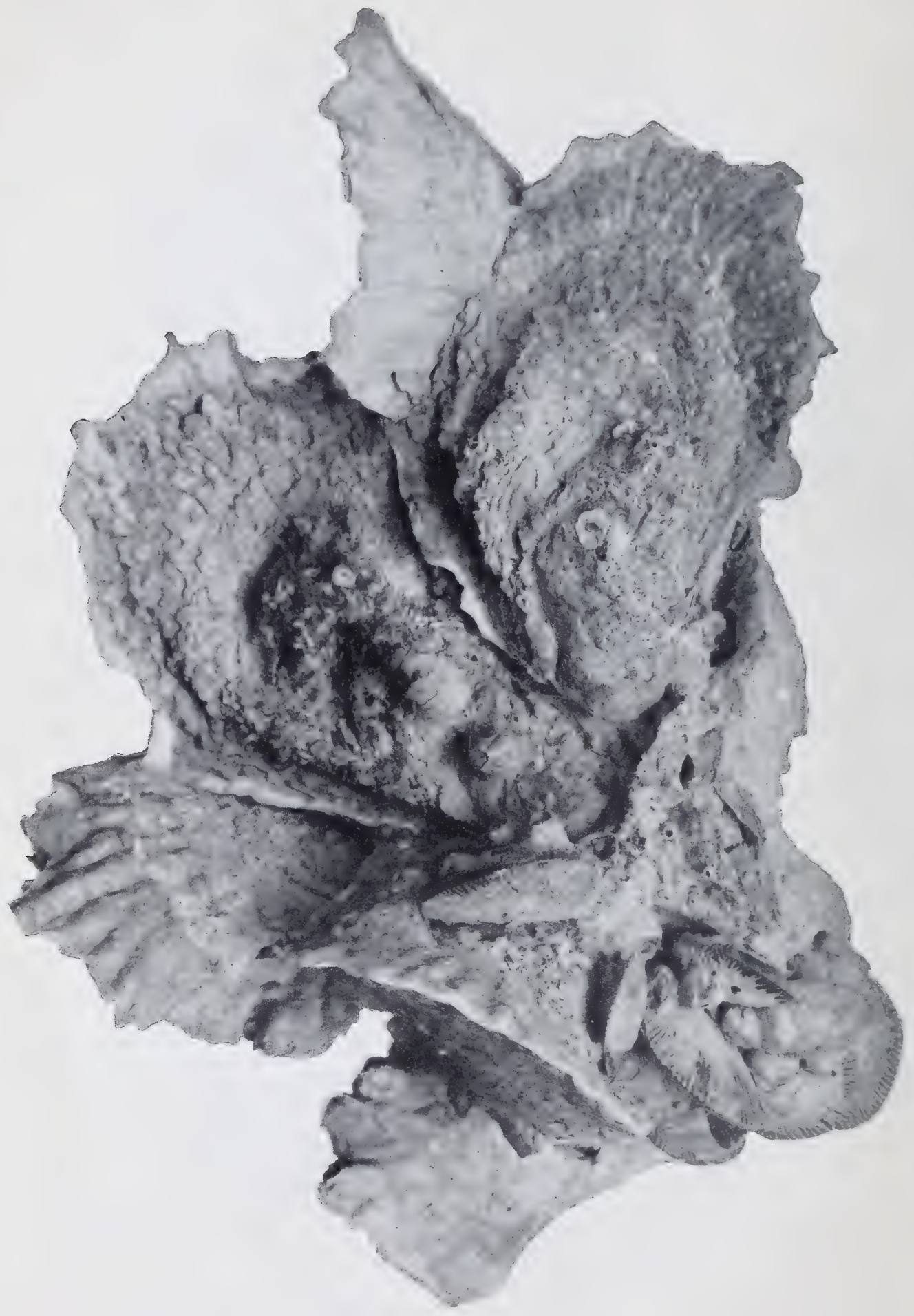

OYSTER CLUSTER FROM STATE-PLANTED BED IN PORTERSVILLE BAY. 


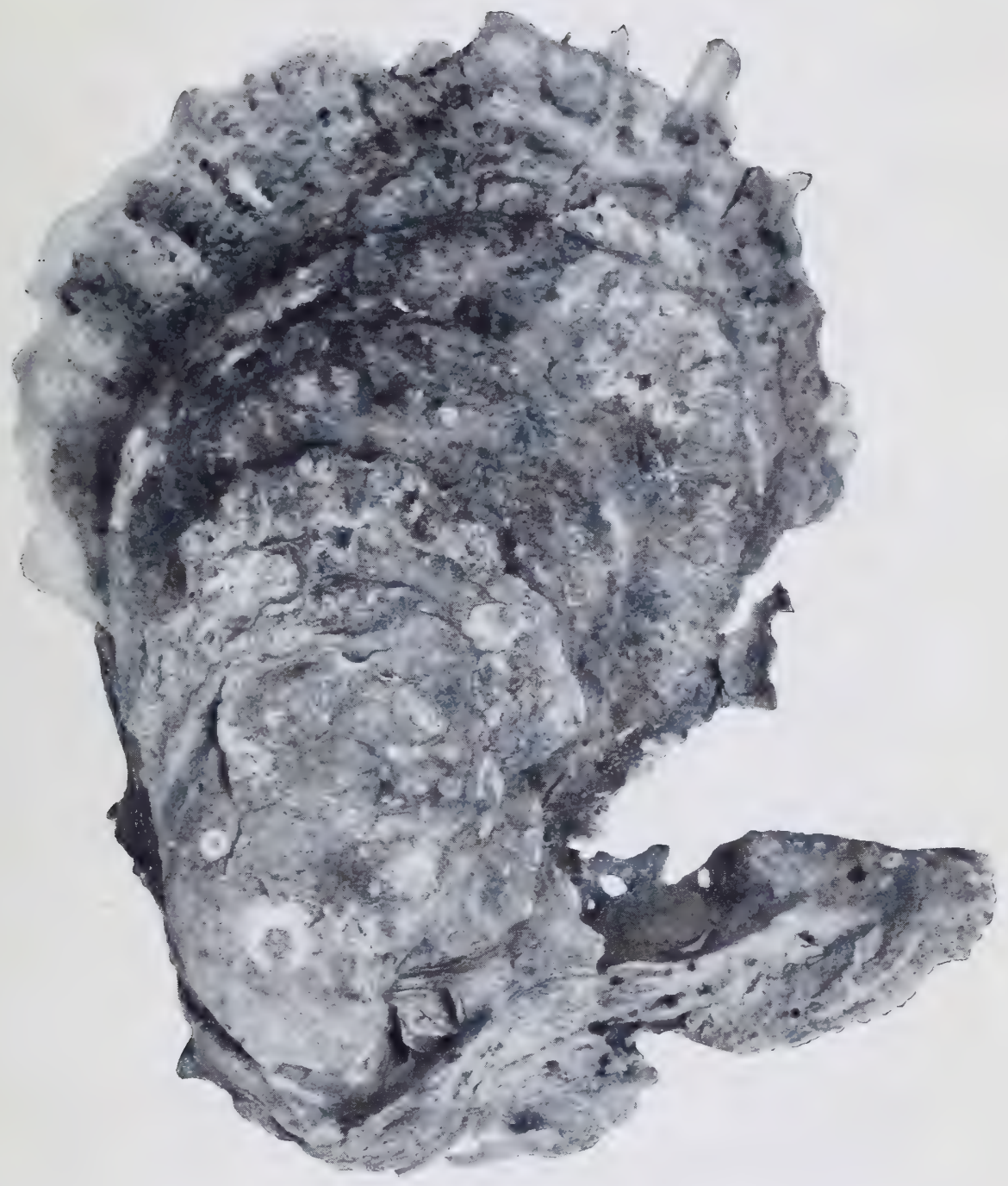

SINGLE OYSTER FROM PRIVATE-PLANTED BED IN PORTERSVILLE BAY. 



\section{DESCRIPTION OF CHART.}

The chart shows the character and location of the natural oyster beds and the barren bottom. The oyster beds are included within solid orange lines and the density of the growth of oysters $c$ rer 3 inches long is indicated by the relative intensity of the shading. In this classific in the small oysters are disregarded and it therefore may happen that a dense growth of oysters under 3 inches in length may occur in an area shown as scattering.

Barren bottom is unshaded, but its character as to consistency is indicated by circular symbols. Hard bottom is shown by solid black circles, ooze by circles with a horizontal diameter, and intermediate consistencies by intermediate symbols. The more open the circle, the softer is the bottom which it represents. Not all stations at which the bottom was tested are shown, the purpose being to indicate the general character and the transitions from one to the other.

Depths are expressed in feet and refer to mean low water.

The triangulation stations of the United States Coast and Geodetic Survey, which were determined with great accuracy and are permanently marked with concrete monuments, are shown by triangles with an included circle.

The subsidiary triangulation stations of the Bureau of Fisheries, less accurately determined and marked by concrete monuments with an iron pipe in the center, are shown by means of circles. The names of the stations are those used by the hydrographic party and are usually abbreviations of the full name used by the Coast and Geodetic Survey.

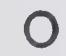





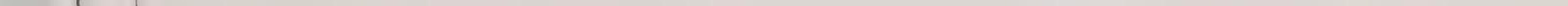





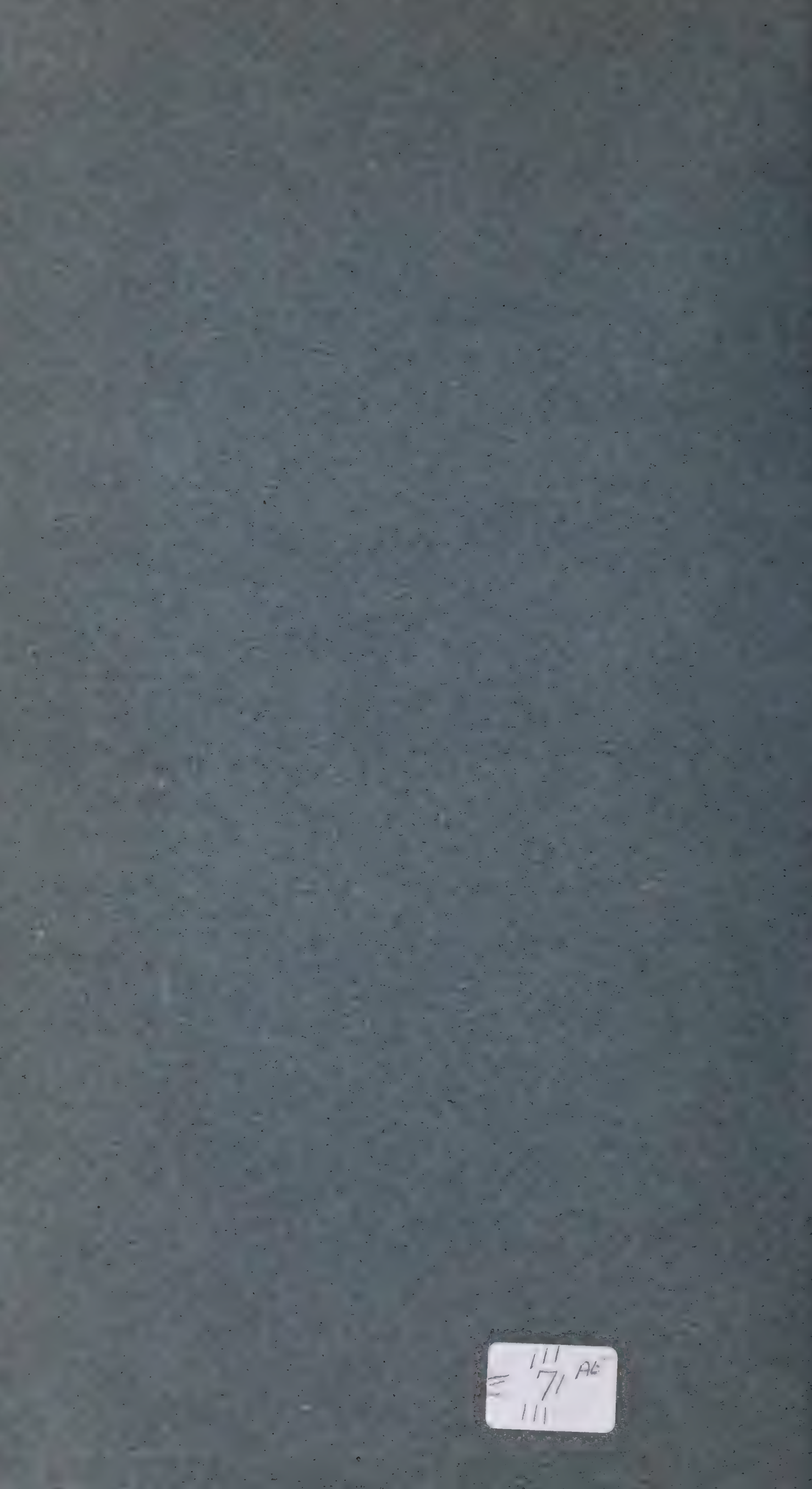



